(1) Nordic Council of Ministers

\title{
Policy instrument evaluation
}

A tool for increasing efficiency in environmental policy 


\section{Policy instrument evaluation}

A tool for increasing efficiency in environmental policy

Emelie Von Bahr, Geir Vasseljen Mørkrid, Kristian Sipiläinen, Peter G. Madsen and Sandra Friis-Jensen

TemaNord 2019:531 
Policy instrument evaluation

A tool for increasing efficiency in environmental policy

Emelie Von Bahr, Geir Vasseljen Mørkrid, Kristian Sipiläinen, Peter G. Madsen and Sandra Friis-Jensen

ISBN 978-92-893-5934-4 (PRINT)

ISBN 978-92-893-5935-1 (PDF)

ISBN 978-92-893-5936-8 (EPUB)

http://dx.doi.org/10.6027/TN2019-531

TemaNord 2019:531

ISSN 0908-6692

Standard: PDF/UA-1

ISO 14289-1

(c) Nordic Council of Ministers 2019

\section{Disclaimer}

This publication was funded by the Nordic Council of Ministers. However, the content does not necessarily reflect the Nordic Council of Ministers' views, opinions, attitudes or recommendations.

Rights and permissions

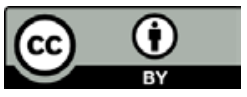

This work is made available under the Creative Commons Attribution 4.0 International license (CC BY 4.0) https://creativecommons.org/licenses/by/4.0

Translations: If you translate this work, please include the following disclaimer: This translation was not produced by the Nordic Council of Ministers and should not be construed as official. The Nordic Council of Ministers cannot be held responsible for the translation or any errors in it.

Adaptations: If you adapt this work, please include the following disclaimer along with the attribution: This is an adaptation of an original work by the Nordic Council of Ministers. Responsibility for the views and opinions expressed in the adaptation rests solely with its author(s). The views and opinions in this adaptation have not been approved by the Nordic Council of Ministers.

Third-party content: The Nordic Council of Ministers does not necessarily own every single part of this work. The Nordic Council of Ministers cannot, therefore, guarantee that the reuse of third-party content does not infringe the copyright of the third party. If you wish to reuse any third-party content, you bear the risks associated with any such rights violations. You are responsible for determining whether there is a need to obtain permission for the use of third-party content, and if so, for obtaining the relevant permission from the copyright holder. Examples of third-party content may include, but are not limited to, tables, figures or images. 
Photo rights (further permission required for reuse):

Any queries regarding rights and licences should be addressed to:

Nordic Council of Ministers/Publication Unit

Ved Stranden 18

DK-1061 Copenhagen K

Denmark

Phone +4533960200

pub@norden.org

\section{Nordic co-operation}

Nordic co-operation is one of the world's most extensive forms of regional collaboration, involving Denmark, Finland, Iceland, Norway, Sweden, and the Faroe Islands, Greenland and Åland.

Nordic co-operation has firm traditions in politics, economics and culture and plays an important role in European and international forums. The Nordic community strives for a strong Nordic Region in a strong Europe.

Nordic co-operation promotes regional interests and values in a global world. The values shared by the Nordic countries help make the region one of the most innovative and competitive in the world.

\section{The Nordic Council of Ministers}

Nordens Hus

Ved Stranden 18

DK-1061 Copenhagen K, Denmark

Tel.: +453396 o200

www.norden.org

Download Nordic publications at www.norden.org/nordpub 



\section{Content}

Preface. .7

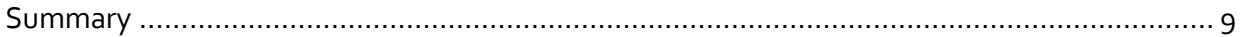

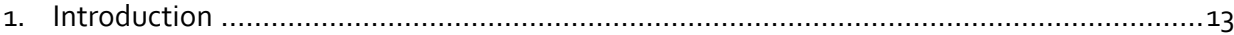

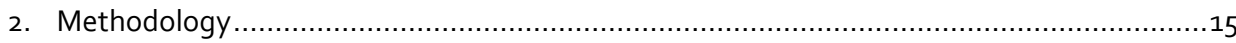

2.1 Definition of policy instrument evaluation ...............................................

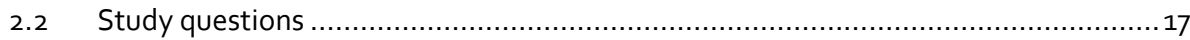

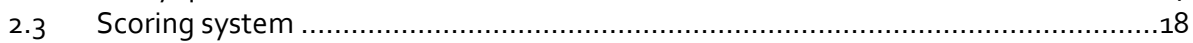

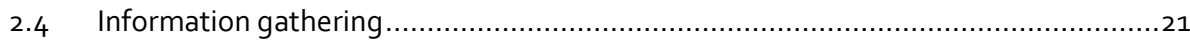

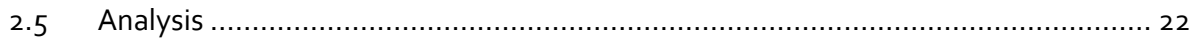

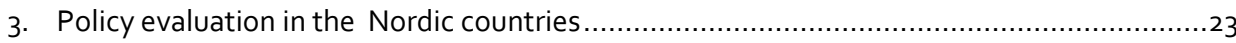

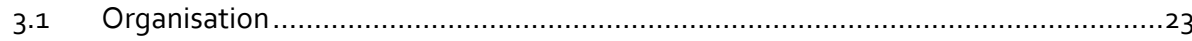

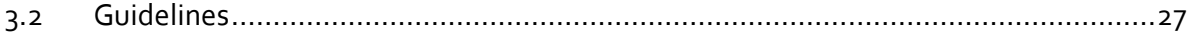

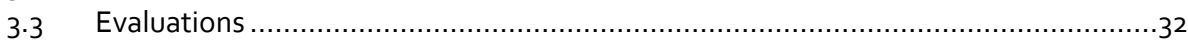

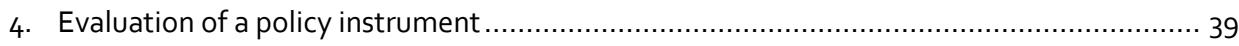

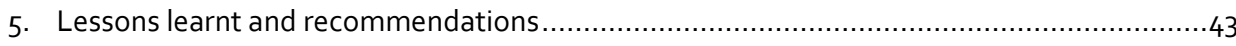

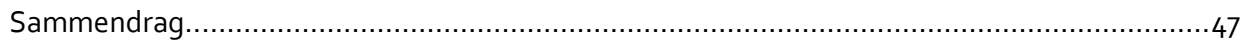

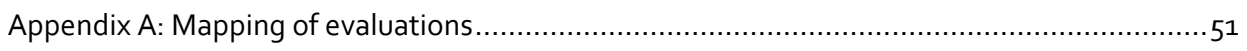

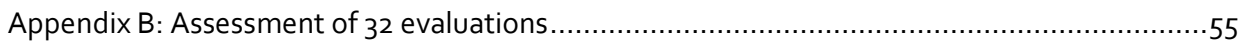

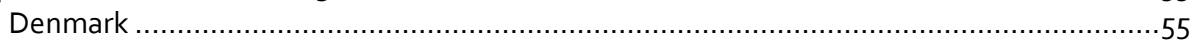

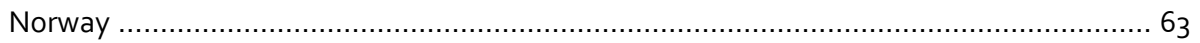

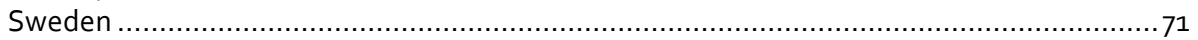

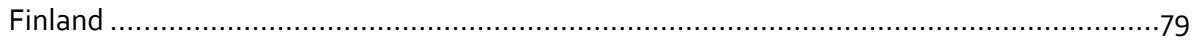

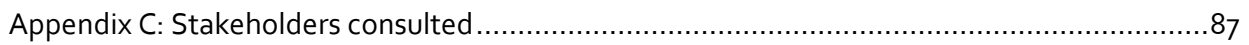

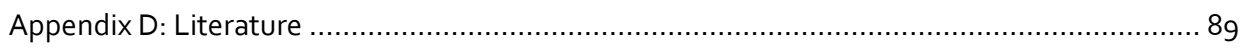




\section{Preface}

The Nordic countries are frontrunners in using economic instruments within the environmental policy field. In theory, well designed economic instruments have the potential to create cost-effective solutions to environmental problems. However, when implementing new policy instruments there are many factors - foreseen or un-foreseen - that may affect the efficiency of the policy.

In order to sustain cost-efficient policy instruments over time, policy evaluation is an important tool. The focus of the report is therefore on the role of evaluations of environmental policies in the Nordic countries and how evaluations could be better implemented in order to create and uphold effective and efficient environmental policies. The report shows, that the Nordic countries have a good and clear setup for conducting ex-ante evaluations, while there is still room for improvement for evaluating the environmental policies ex-post.

The report was funded by the Environment and Economy Group (MEG) of the Nordic Council of Ministers and prepared by COWI.

September 2018

Signe Krarup

Chairman of the Working Group

on Environment and Economy

under the Nordic Council of Ministers 


\section{Summary}

This study analyses the role of evaluations for environmental policies in the Nordic countries (Denmark, Finland, Norway and Sweden) and discusses how environmental policy instrument evaluations could be better implemented in order to create and uphold effective and efficient environmental policies. A policy is effective if it is successful in achieving or progressing towards its objectives, while it is efficient if the policy interventions has been cost effective and so the costs can be justified by the changes it has achieved.

The focus of the study is on evaluations of environmental policy measures in the Nordic countries that contain economic instruments as well as policy instruments.

The study has been conducted by COWI A/S under supervision of the Environment and Economy Group of the Nordic Council of Ministers. The Environment and Economy Group is a multi-sectoral group with a mandate approved by both the environment sector and the finance sector of the Nordic Council of Ministers.

The study investigates the role of both ex-ante and ex-post evaluations for environmental policies, i.e. assessments of policies before and after they are implemented (cf. table 1 for a more detailed definition of ex-ante and ex-post evaluations).

Table 1: Ex-post and ex-ante evaluations, Definitions

Type Definition

Ex-ante evaluation

Ex-ante evaluations (1) must set out the logical reasoning that links the problem, its underlying causes, the objectives and a range of policy instruments to tackle the problem. They must present the likely impacts of the policy instruments, who will be affected by them and how.

Ex-ante evaluations must compare the policy instruments on the basis of their assessed economic, social and environmental impacts.

Ex-post evaluation Ex-post evaluations (2) aim to inform policy makers about existing policy instruments
regularly ( 3 ), and to ensure that relevant evidence is available to support the preparation of new
initiatives ("evaluate first" principle).

As a minimum, ex-post evaluations must assess effectiveness, efficiency, relevance and coherence. Assessments of efficiency should always aim to quantify regulatory costs and benefits and identify burdensome or complex aspects of legislation and its implementation.

All ex-post evaluations must assess all significant economic, social and environmental impacts.

Notes: (1) Ex-ante evaluations are called impact assessments (IA) in the BRG.

(2) Ex-post evaluations are frequently referred to as evaluations.

(3) Ideally carried out on a regularly basis, but in practice often an ad-hoc basis.

Source: COWI - inspired by the so-called Better Regulation Guidelines (BRG) developed and issued by the European Commission (for information about the BRG, see: https://ec.europa.eu/info/betterregulation-toolbox_en). 
The study focuses on three main areas in regard to ex-ante and ex-post evaluations:

- Organisation: How environmental policy evaluations are organised in the different Nordic countries - i.e. who are the typical clients and evaluators and what are the requirements in regard to conducting evaluations?

- Guidelines: Which types of guidelines exist for conducting ex-ante and ex-post evaluations?

- Specific evaluations: We look into 32 already conducted evaluations of environmental policies - i.e. 8 ( 4 ex-post and 4 ex-ante) in each of the four Nordic countries. We do this to look for good, but possibly also less good elements of the evaluations to learn from.

To investigate these three areas, we have set up a number of study questions for each area, developed a scoring system and conducted a number of interviews.

As a result of the analysis, we have found a number of lesson learnt shown in Table 2 for the three investigated areas. Based on the lesson learnt we have then developed a number of recommendations on how to improve the evaluation of environmental policies.

Overall, the results of the study show that the Nordic countries have a good and clear organisational setup for conducting ex-ante evaluations while there is room for improvement for evaluating the environmental policies ex-post. Only Finland has a requirement and a process for conducting ex-post evaluations of environmental policies. In regard to the organisational setup, we therefore recommend that:

- Evaluators in Denmark, Norway and Sweden look to Finland for inspiration to establish ex-post evaluation requirements that mirror ex-ante evaluation requirements, thereby encouraging a consistent policy cycle evaluation process.

In all the Nordic countries, it is a requirement that ex-ante evaluations are carried out for environmental policies, where the impact is expected to be large and there are guidelines describing how these evaluations should be conducted. However, there is some variation in how the evaluation guidelines in the different Nordic countries cover the environmental policy domain.

In regard to the guidelines for evaluations we have the following recommendations:

- There seems to be room for exchange of good practices. For example, others may be inspired by the use of Danish catalogue of environmental indicator values in evaluations, and the Swedish evaluation guidelines for environmental policies may inspire others to be more specific; 
- Ex-ante guidelines should ensure a solid foundation for the ex-post evaluation. To carry out a good ex-post evaluation, it is important that good indicators are identified and introduced at an early stage, i.e. in the ex-ante evaluation when defining the baseline. Most important in this regard is that collection of data to be used in ex-post evaluations may be carried out on a regular basis;

- There is a need to develop specific guidelines for conducting ex-post evaluations. These guidelines may be inspired by the BRG developed and issued by the European Commission and its accompanying toolbox. ${ }^{1}$

Even though there are no requirements or guidelines for conducting ex-post evaluations, we have in the study of the already conducted evaluations not found a strong tendency that the ex-ante evaluations are better than the ex-post evaluations when it comes to the definition and coverage of impacts and to the use of analytical tools. However, the study of the specific evaluations shows that it is not always clear which effects are included in the evaluation as well as the limitations related to estimating the effects. Furthermore, the study of the already conducted evaluations also indicate that the use of stakeholders is limited. Based on the analysis of the already conducted evaluations, we therefore have the following recommendations:

- The used, not officially documented, good methodologies should be made public - not least to encourage that evaluations results from different evaluations become more comparable;

- Recommendations and best practices for involving stakeholders should be included in the guidelines for evaluations. 


\section{Table 2: Lessons learnt}

Overview

\section{Organisation}

1. There are many different clients as well as evaluators, in all four Nordic countries. In itself, this points to a benefit from having common, widely-used evaluation methodologies encouraging that evaluations of different environmental policies are comparable - and so helping choosing the right ones in the future.

2. In contrast to Denmark, Norway and Sweden Finland has established ex-post evaluation requirements that mirror ex-ante evaluation requirements, thereby encouraging a consistent policy cycle evaluation process.

3. The Finnish Council of Regulatory Impact Analysis - that seems to be inspired by the European Commission's Regulatory Scrutiny Board - facilitates a formal way of monitoring that evaluations follow a consistent approach and are of good quality.

\section{Evaluation guidelines}

4. Most of the evaluation guidelines in all the Nordic countries are mainly applicable to ex-ante evaluations, and thus do not play much of a role in encouraging comparability between ex-ante and ex-post evaluations - and, in turn, in encouraging consistent policy cycles.

5. All the Nordic countries have more than one (ex-ante) evaluation guideline. The different guidelines shall, however, always be in compliance with the guidelines from the Ministry of Finance. Some of the guidelines focus on the evaluation process, while others focus on the use of analytical methods. Both types of guidance are overall of good quality.

6. Only few evaluation guidelines explain the use of and the benefit from stakeholder consultation - i.e. how it can contribute to the impact evidence base and how it can help to ensure wide acceptance and, thereby, usability of the evaluation results.

7. There is some variation in how the evaluation guidelines in the different Nordic countries specifically cover the environmental policy domain.

8. In general, the evaluation guidelines pay limited attention to cross-border impacts, although such impacts often can be significant. Furthermore, there is a discrepancy in some of the Nordic countries (e.g., Denmark) between guidelines of ministries of environment and ministries of finance with regard to cross-border impacts. As a rule, guidelines of ministries of finance exclude cross-border impacts.

\section{Already conducted evaluations}

9. Some evaluations have both ex-ante and ex-post elements. This can be problematic for the use of the evaluation results if it is not clear which of the results concern ex-post findings for the relevance, efficiency and effectiveness of policies, and which concern the assessment of the likely impacts of future environmental policies.

10. Apart from Denmark, there is not a strong tendency that ex-ante evaluations define, cover and analyse impacts better than ex-post evaluations although evaluation guidelines almost only are available for ex-ante evaluations.

11. The coverage of impacts in the evaluations, hereunder whether they only cover narrow (e.g. environmental) or also wider impacts on the society, is not always clear - limiting comparisons of the policy instruments being evaluated.

12. Stakeholder consultation is more frequently used within ex-post evaluations than within ex-ante evaluations. For the latter, there seems thus to be missed opportunities regarding obtaining evidence for and regarding securing wide acceptance of the evaluation results. 


\section{Introduction}

This study analyses the role of evaluations for environmental policies in the Nordic countries (Denmark, Finland, Norway and Sweden), foremost the extent to which they are conducted and how, and discusses how environmental policy instrument evaluations could be better implemented in order to create and uphold effective and efficient environmental policies. A policy is effective if it is successful in achieving or progressing towards its objectives, while it is efficient if the policy interventions has been cost effective and so the costs can be justified by the changes it has achieved.

The Nordic countries are by many seen as frontrunners in developing and, not least, implementing environmental policies. To maintain this situation, there may be a need to improve the way in which the evaluation tool is used within the policy-making cycle. Hence, there may be a need to better evaluate and document the effects of already implemented environmental policies - via ex-post evaluations ${ }^{2}$ - as well as a need for better analyses of the likely effects of possible future policies - via ex-ante evaluations. ${ }^{3}$

The study has been conducted by COWI A/S (henceforth: COWI) under supervision of the Environment and Economy Group of the Nordic Council of Ministers. The Environment and Economy Group is a multi-sectoral group with a mandate approved by both the environment sector and the finance sector of the Nordic Council of Ministers.

We aim with this study to contribute to the use of the evaluation tool in the Nordic countries. However, other countries may also benefit from our findings. We do this by adding to the policy evaluation capabilities in the Nordic countries by documenting a number of lessons learnt from how environmental policy evaluations are carried out at present, and by providing recommendations for how civil servants and/or external evaluators can make better use of the evaluation tool - in particular by learning from practices in other Nordic countries. This also means that the purpose is not to develop a new evaluation guideline to be used in all the Nordic countries. From the start of the study, we acknowledged that such an approach would not be feasible because it would disregard the fact that the Nordic countries have different policy cultures, such as requirements or ways of carrying out evaluations of environmental policies.

Our findings are reached via applying a methodology that defines what an evaluation is, and that defines a scoring system to help answer a number of study questions. The methodology is presented in Chapter 2.

${ }^{2}$ Frequently referred to as evaluations.

3 Frequently referred to as impact assessments. 
In Chapter 3, we then assess the strengths and weaknesses of the existing evaluation guidelines and the methodologies applied when conducting environmental policy instrument evaluations in the different Nordic countries.

This assessment is in Chapter 4 accompanied by a "cold case" evaluation of the "Effect assessment of chemical initiatives 2014-2017", conducted for the Danish Ministry of Environment and Food by COWI. Here we explain how this already conducted evaluation could have provided better evidence if the identified weaknesses had been overcome.

Finally, we present in Chapter 5 the main lessons learnt and provide recommendations for how these lessons may lead to improvements in the use of the evaluation tool within the environmental policy field in the Nordic countries. Focus is here on providing a robust basis for allowing each country to develop its own priorities for improving environmental policy evaluation practices. However, through increased sharing of good practices among the Nordic countries, a more "harmonised Nordic approach" will form, and consequently more comparable evidence of the effectiveness and efficiency of policy instruments within the environmental field will be available.

Four appendices are attached. Appendix A provides a non-exhaustive mapping of environmental policy evaluations conducted in Denmark, Norway, Sweden and Finland in the period 2011-2017. Appendix B provides for each of the 32 selected already conducted evaluations details of their assessed strengths and weaknesses. Appendix $C$ informs on the stakeholders consulted. Finally, Appendix $D$ lists the literature made use of - in addition to that presented in Appendix A. 


\section{Methodology}

The methodology applied is presented in five sections. First, we provide a definition of policy instrument evaluation that has guided what we have been looking for in existing evaluation guidelines and in the methodologies applied when conducting evaluations in the different Nordic countries. Second, we present the specific study questions that we provide answers to in the report. Third, we present the scoring system that has helped us to provide the answers. Fourth, we describe the gathering of information needed to answer the study questions. Finally, we explain how we have used the information in the analysis.

\subsection{Definition of policy instrument evaluation}

To define policy instrument evaluation, we first define what we mean by environment policy instruments. Here, as shown in Table 3, we make use of the typology suggested by Norden (2014), which is based on the analysis presented in Konjunkturinstitutet (2012). We study economic instruments as well as other types of policy instruments used within the environmental policies of the Nordic countries. In other words, we do not only analyse evaluation practices for policy instruments that aim at adjusting prices of goods and services to reflect environmental externalities, or that provide carrots in the form of tax credits, grants and support.

Table 3: Types of policy instruments

\begin{tabular}{llll} 
Economic & Administrative & Informational & Research \\
Taxes & Legislation & Creating awareness & Research \\
Tax credits & Norms & Eco-labelling & Development \\
Fees & Limits & Counselling & Demonstration \\
Grants & Long-term contracts & Education & Technology and system evaluation \\
Subsidies & Environmental classification & Shaping public opinion & \\
Deposit-refund systems & Regulation & & \\
Emissions trading & Technical requirements & & \\
Certificates trading & Testing & & \\
Environmental compensation & Supervision & & \\
& Target management & & \\
\hline
\end{tabular}

Source: Norden (2012) and Konjunkturinstitutet (2012). 
Policy instrument evaluations have in recent years gained momentum - not least at EU level with the adoption of the Better Regulation agenda in 2015 and the Better Regulation Guidelines (BRG). ${ }^{4}$ Actually, the BRG have been revised as recently as in July 2017 (European Commission, 2017). The BRG covers the entire policy-making cycle and intends to boost openness, effectiveness and efficiency of the EU policy-making process and thus improve the quality of new proposals through better ex-ante evaluations, and to promote constant and consistent review of existing EU laws and policies through ex-post evaluations.

We have, as shown in Table 4, been inspired by the definitions provided by the BRG. Hence, we have addressed the issues covered by these definitions when assessing the identified guidelines and ex-ante and ex-post evaluations. When doing this, we acknowledge that evaluations are of different scope/ambition, most often depending on the scope/comprehensiveness of the evaluated policy instrument. For example, the application of a full cost-benefit analysis (CBA) or the use of the impact evaluation (IE) approach is complex and mostly only used for comprehensive policies. Furthermore, by defining a scoring system (see Section 2.3) we explain what we consider characterises a good evaluation.

Table 4: Ex-ante and ex-post evaluations, Definitions
Type Definition

Ex-ante evaluation

Ex-ante evaluations (1) must set out the logical reasoning that links the problem, its underlying causes, the objectives and a range of policy instruments to tackle the problem. They must present the likely impacts of the policy instruments, who will be affected by them and how.

The ex-ante evaluations must compare the policy instruments on the basis of their economic, social and environmental impacts.

Ex-post evaluation

Ex-post evaluations (2) aim to inform policy makers about existing policy instruments regularly, and to ensure that relevant evidence is available to support the preparation of new initiatives ("evaluate first" principle).

As a minimum, ex-post evaluations must assess effectiveness, efficiency, relevance and coherence. Assessments of efficiency should always aim to quantify regulatory costs and benefits and identify burdensome or complex aspects of legislation and its implementation.

All ex-post evaluations must assess all significant economic, social and environmental impacts.

Notes: (1) Ex-ante evaluations are called impact assessments (IA) in the BRG.

(2) Ex-post evaluations are frequently referred to as evaluations.

Source: COWI - inspired by the so-called Better Regulation Guidelines (BRG) developed and issued by the European Commission (for information about the BRG, see: https://ec.europa.eu/info/betterregulation-toolbox_en).

4 Cf. https://ec.europa.eu/info/law/law-making-process/better-regulation-why-and-how_en and also https://ec.europa.eu/info/better-regulation-toolbox_en 
The definitions in the table mention neither environmental policies nor economic instruments explicitly. Hence, they are not exclusive to these, but applicable to policy instruments in general. Furthermore, it may be worth mentioning that there are other types of evaluations than policy instrument evaluations. There are, for example, organisational or process evaluations assessing the workings and performance of organisations; project evaluations assessing the impact of e.g. specific infrastructure projects and programme evaluations where the activities undertaken by ministries and agencies are assessed against a set of objectives or criteria.

\subsection{Study questions}

The study's starting point was a number of study questions. Table 5 lists these and introduces our overall approach to providing answers to these. Hence, as described further in the following sections, we have made use of desk study information to map and assess existing ex-post and ex-ante evaluation guidelines and already conducted evaluations of environmental policies. We have then consulted stakeholders in Denmark, Norway, Sweden and Finland to obtain comments on our preliminary findings, thereby contributing to the final answering of the study questions, see Appendix C. 
To what extent are ex-ante evaluations conducted?

To what extent are ex-post evaluations conducted?

\section{when and how evaluations are to be}

Are there national guidelines about conducted?

How do ex-ante and ex-post evaluations compare in terms of methods, data availability etc.?

Are evaluations conducted systematically or ad-hoc, and are they performed internally or by external consultants?

How is the independence and integrity of evaluations guaranteed?

To what extent do evaluations inform policy development?
Mapping of ex-ante evaluations conducted in Denmark, Norway, Sweden and Finland since 2011 - i.e. counting the number of evaluations, hereunder the number that addresses economic instruments, and comparing the numbers among the Nordic countries.

Gathering stakeholder assessments of the share of environmental policies hereunder of economic instruments - that have been subject to ex-ante evaluations.

Mapping of ex-post evaluations conducted in Denmark, Norway, Sweden and Finland since 2011 - i.e. counting the number of evaluations, hereunder the number that addresses economic instruments, and comparing the numbers in between the Nordic countries.

Gathering stakeholder assessments of the share of environmental policies hereunder of economic instruments - that have been subject to ex-post evaluations

Mapping of national ex-ante and ex-post evaluation guidelines, focus being on requirements to the timing of evaluations, to the types of policies to be evaluated, and to the evaluation methodologies to be applied.

Assessing comparability/consistency between national ex-ante and ex-post guidelines and between already conducted evaluations - e.g., with respect to definitions and coverage of environmental and other impacts, to use of data, and to methods for assessing effects of environmental policy instruments. Hence, overall assessing consistency within the policy-making cycle.

Based on the above mappings of evaluations and evaluation guidelines, characterising the extent of systematics vs. ad-hoc approach, and the extent of using external consultants.

Looking into the extent to which evaluations are carried out internally or by external evaluators.

Assessing how evidence from ex-post evaluations is used within ex-ante evaluations - and the other way around.

Gathering stakeholder assessments of the extent to which evaluations inform policy development.

Assessing strengths and weaknesses of the evaluation methods applied - and thus assessing the quality of the evidence provided by the evaluations.

Source: MEG invitation to tender and COWI.

\subsection{Scoring system}

As input to answering the above study questions, we have made use of a scoring system developed for the present study. Table 6 shows that the scoring system covers three central areas, i.e. what we mean by the extent, the quality, and the consistency of the evaluation approaches. We make use of the semi-quantitative scores, high $(H)$, medium $(M)$, or low $(L)$, for a number of indicators that are connected to the study questions. The specific scores have been determined in an iterative process between COWI and the interviewed stakeholders.

It must be underlined that many of the definitions of the indicators as well as of the criteria for assigning the scores are not entirely precise. This can of course be seen as a weakness of the approach. However, we believe that it is not feasible - and therefore 
not usable - to define more precise indicators and criteria. Actually, we also consider it as a strength because it allows for some flexibility and does not prevent scoring. In other words, the aim of the scoring system has rather been to encourage that the right characteristics of the evaluation guidelines and already conducted guidelines are assessed, rather that calculating and comparing overall scores. In this context, we acknowledge that a ranking of the guidelines and evaluations using such scores may depend on their number. For instance, if only few evaluations have been made, it may not provide a robust representation of these.

Regarding the extent of evaluations (1), we have been looking for information to overall being able to assess and compare which of the Nordic countries evaluate most of their environmental policies - ex-ante as well as ex-post. A well-defined indicator here is the share of environmental policies evaluated (1.1). This is, however, not straightforward to measure as this would require a counting of both evaluations and policies. Furthermore, such account would comprise both comprehensive and less comprehensive evaluations, and the same goes for policies. Hence, the assignment of the scores is mainly done via stakeholder views.

The study provides a non-exhaustive list of environmental policy evaluations conducted in Denmark, Norway, Sweden and Finland in the period 2011-2017 (see Appendix A). In this connecting it is worth mentioning we do not have an estimate for the number of environmental policy evaluations that have been carried out (1.2).

The issue of whether the comprehensiveness of the evaluations reflects the comprehensiveness of the policy and thus the policy impact is assessed further in (1.3). For the evaluation guidelines, we have assessed whether the evaluation requirements depend on the expected policy impact. A high score is here given if the guideline clearly specifies why an evaluation shall take place, and how the evaluator shall focus on significant impacts.

Finally, within this first area, we have assessed the requirements to regularity (1.4), i.e. the extent to which the guideline specifies when an evaluation shall take place. A high score is here given if the requirements to timing include a specification of how the evaluation will contribute to the policy-making process. 
Table 6: Scoring system

\begin{tabular}{|c|c|c|c|c|}
\hline No. & Indicator & High (H) & Medium (M) & Low (L) \\
\hline 1 & \multicolumn{2}{|l|}{ Extent of evaluations/guidelines } & & \\
\hline 1.1 & $\begin{array}{l}\text { Share of environmental } \\
\text { policies evaluated }\end{array}$ & $>75 \%$ & $25-75 \%$ & $<25 \%$ \\
\hline 1.2 & $\begin{array}{l}\text { Number of environmental } \\
\text { policy evaluations }\end{array}$ & $\begin{array}{l}\text { Above average of Nordic } \\
\text { countries }\end{array}$ & $\begin{array}{l}\text { Around average of } \\
\text { Nordic countries }\end{array}$ & $\begin{array}{l}\text { Below average of Nordic } \\
\text { countries }\end{array}$ \\
\hline 1.3 & $\begin{array}{l}\text { Proportionality of evaluation } \\
\text { to policy impact }\end{array}$ & $\begin{array}{l}\text { Evaluation requirements } \\
\text { depend on policy impact }\end{array}$ & $\begin{array}{l}\text { Evaluation } \\
\text { requirements depend } \\
\text { somewhat on policy } \\
\text { impact }\end{array}$ & $\begin{array}{l}\text { Evaluation requirements do not } \\
\text { depend on policy impact }\end{array}$ \\
\hline 1.4 & Requirements to regularity & $\begin{array}{l}\text { All (comprehensive) } \\
\text { environmental policies are } \\
\text { timely evaluated in the } \\
\text { policy-making process }\end{array}$ & $\begin{array}{l}\text { Few/some } \\
\text { requirements to the } \\
\text { timing of evaluations } \\
\text { in the policy-making } \\
\text { process }\end{array}$ & $\begin{array}{l}\text { No requirements to the timing of } \\
\text { evaluations in the policy-making } \\
\text { process }\end{array}$ \\
\hline 2 & \multicolumn{2}{|c|}{ Quality of evaluations/guidelines } & & \\
\hline 2.1 & $\begin{array}{l}\text { Definitions and coverage of } \\
\text { impacts }\end{array}$ & $\begin{array}{l}\text { Well-defined and } \\
\text { comprehensive coverage of } \\
\text { impacts }\end{array}$ & $\begin{array}{l}\text { Acceptable } \\
\text { definitions but not } \\
\text { complete coverage } \\
\text { of impacts }\end{array}$ & $\begin{array}{l}\text { Unspecific definitions and only } \\
\text { partial coverage of impacts }\end{array}$ \\
\hline 2.2 & $\begin{array}{l}\text { Comparability between ex- } \\
\text { ante and ex-post evaluation } \\
\text { guidelines regarding impacts }\end{array}$ & Full comparability & Some comparability & No comparability \\
\hline 2.3 & $\begin{array}{l}\text { Use of analytical methods } \\
\text { for measuring impacts }\end{array}$ & $\begin{array}{l}\text { Much use of analytical } \\
\text { methods }\end{array}$ & $\begin{array}{l}\text { Some use of } \\
\text { analytical methods }\end{array}$ & $\begin{array}{l}\text { No or little use of analytical } \\
\text { methods }\end{array}$ \\
\hline 2.4 & $\begin{array}{l}\text { Comparability between ex- } \\
\text { ante and ex-post guidelines } \\
\text { regarding use of analytical } \\
\text { methods }\end{array}$ & Full comparability & Some comparability & No comparability \\
\hline 2.5 & Stakeholder consultation & $\begin{array}{l}\text { Much use as evidence base } \\
\text { and for acceptance of } \\
\text { evaluation results }\end{array}$ & $\begin{array}{l}\text { Some use as } \\
\text { evidence base and } \\
\text { for acceptance of } \\
\text { evaluation results }\end{array}$ & $\begin{array}{l}\text { No or little use as evidence base } \\
\text { and for acceptance of evaluation } \\
\text { results }\end{array}$ \\
\hline 2.6 & Independency & $\begin{array}{l}\text { High independency and } \\
\text { integrity of evaluators }\end{array}$ & $\begin{array}{l}\text { Medium } \\
\text { independency and } \\
\text { integrity of } \\
\text { evaluators }\end{array}$ & $\begin{array}{l}\text { Low independency and integrity } \\
\text { of evaluators }\end{array}$ \\
\hline 3 & \multicolumn{2}{|c|}{ Consistency of evaluations/guidelines } & & \\
\hline 3.1 & $\begin{array}{l}\text { Role of evaluation in policy } \\
\text { cycle }\end{array}$ & Explicit role & Some role & No explicit role \\
\hline 3.2 & $\begin{array}{l}\text { Comparability of economic } \\
\text { instruments with other } \\
\text { policy instruments }\end{array}$ & Full comparability & Some comparability & No comparability \\
\hline
\end{tabular}

Source: COWI. 
Regarding the quality of the evaluations and of the evaluation guidelines (2), we have looked at whether the expected impacts of the environmental policy instruments are well-defined (2.1), and whether the coverage of impacts is comprehensive and goes beyond environmental impacts to also cover economic impacts - e.g. administrative costs - and social costs. Hence, we have assessed whether the impacts covered are sufficient ex-post to assess the relevance, effectiveness, efficiency, and coherence of existing policies, and ex-ante to assess the likely impact of future policies. Furthermore, in the context of assessing coverage and consistency of the policy-making cycle, we compare the definitions and coverage of impacts between the ex-ante and the ex-post evaluation guidelines.

We have also looked at the use of analytical methods (2.3) to measure the defined impacts. Hence, we have looked for the use of approaches such as cost-benefit analyses and cost-effectiveness analyses, as well as for the use of analytical models, e.g. CGE, or econometric models. Furthermore, we have compared the use of analytical methods between ex-ante and ex-post evaluations and evaluation guidelines (2.4).

Furthermore, we have looked into the requirements in the evaluations guidelines to the use of stakeholder consultation (2.5) as well as the actual use in already conducted evaluations. In this respect, we have assessed how stakeholders are used as evidence base for measuring impacts and how stakeholders are consulted in the process of getting acceptance of the evaluation results.

Finally, within this second area, we have assessed any requirements to the independency (2.6) or integrity of the evaluators - internal or external - who have been involved in the analysed evaluations.

The third area regarding the consistency of the evaluations and of the evaluation guidelines (3) is to some extent summing up on the other two areas. First, we conclude on the roles of the ex-ante and ex-post evaluations in the policy cycle (3.1), i.e. whether such roles are explicitly specified in the evaluation guidelines. Second, we conclude on the comparability of how economic instruments are evaluated vis-à-vis other policy instruments (3.2).

\section{$2.4 \quad$ Information gathering}

As introduced above, the study questions have been answered using different information sources. We have, as listed in Appendices A and $D$, analysed written material, and we have, as listed in Appendix $C$, consulted a number of stakeholders in Denmark, Norway, Sweden and Finland.

The stakeholders have been identified by applying the so-called "snowball" methodology, where we have used an interview with one key stakeholder to identify other key stakeholders who they find have the best insight into existing evaluation guidelines and into policy instrument evaluations that have been conducted in recent years within the field of environmental policy. The key stakeholders are government officers, researchers, private companies or non-governmental organisations. 
In practice, first, most of the written material has been gathered and analysed to get preliminary answers to the study questions. The stakeholders have then partly been asked to comment on these preliminary answers and on the coverage/suitability of the identified evaluation guidelines and already conducted evaluations. Furthermore, they have partly been asked to provide additional information and views, hereunder to provide their recommendations for improvements in the use of the evaluation tool within the environmental policy field in the Nordic countries.

\subsection{Analysis}

As presented in Chapter 3, we have first, on the basis of the gathered written material and the information provided by the stakeholders, described how evaluation activities for environmental policies are organised in the different Nordic countries.

From this starting point, we have assessed all the relevant national evaluation guidelines identified in Denmark, Norway, Sweden and Finland. Furthermore, we have searched for inspiration from guidelines elsewhere. Hence, we answered the respective study questions, hereunder provided values to the relevant scoring indicators.

Regarding the analysis of already conducted evaluations, we selected, as shown in Section 3.3, 32 evaluations, i.e. 8 (4 ex-post and 4 ex-ante) in each of the four countries: Denmark, Norway, Sweden and Finland. In the selection process, we have made use of the scoring system in order to cover high, medium and low scoring evaluations. In this context, we asked the consulted national stakeholders to point to evaluations that we can learn from particularly. 


\section{Policy evaluation in the Nordic countries}

In this chapter, we provide both an assessment of the evaluation guidelines used in the Nordic countries and an assessment of the methodologies applied in already conducted evaluations of environmental policies.

\subsection{Organisation}

To set the stage for this analysis, we start with a brief description of how environmental policy evaluations are organised in the different Nordic countries - i.e. who are the typical evaluators.

As a rule, there are often more formal requirements to ex-ante evaluations than to ex-post evaluations. This has consequences for the way the evaluations are organised and anchored (e.g. role of ministries in evaluations). Furthermore, both ex-ante and expost evaluations of large environmental policy initiatives are typically carried out by external evaluators (consultancy firms or research institutes), while minor ones are typically carried out internally in ministries/agencies. Hence, in these cases - although different staff may be involved - the client and the evaluator coincide.

Table 7 reveals that there are several different clients and types of evaluators, in particular in Denmark and Sweden - in Sweden, many different government agencies. However, in Norway, also smaller evaluations are carried out within a ministry or agency. Such internal ex-ante evaluations are guided by an instruction ${ }^{5}$ where six questions have to be answered. All the Nordic countries also have a National Audit Office, which audits public spending and seeks to strengthen the accountability of public administration. The National Audit Office can choose to evaluate different policies ex-post, including environmental policies. The National Audit Office typically focuses on large policy initiatives.

The evaluation experience is thus scattered over many actors. This might, on the one hand, imply that there is a large resource base for carrying out evaluations and the possibility of establishing a forum for sharing evaluation practices. On the other hand, it may imply that different evaluation methodologies are applied - not least for ex-post evaluations where common guidelines very rarely exist (see Section 3.2). A first lesson learnt from the mapping exercise is therefore:

5 Instruks om utredning av statlige tiltak, fastsatt ved kongelige resolusjon 2016. 
1. There are many different clients as well as evaluators, in all four Nordic countries. In itself, this points to a benefit from having common, widely-used evaluation methodologies encouraging that evaluations of different environmental policies are comparable - and so helping choosing the right ones in the future.

Table 7: Organisation of environmental policy instrument evaluations in the Nordic countries

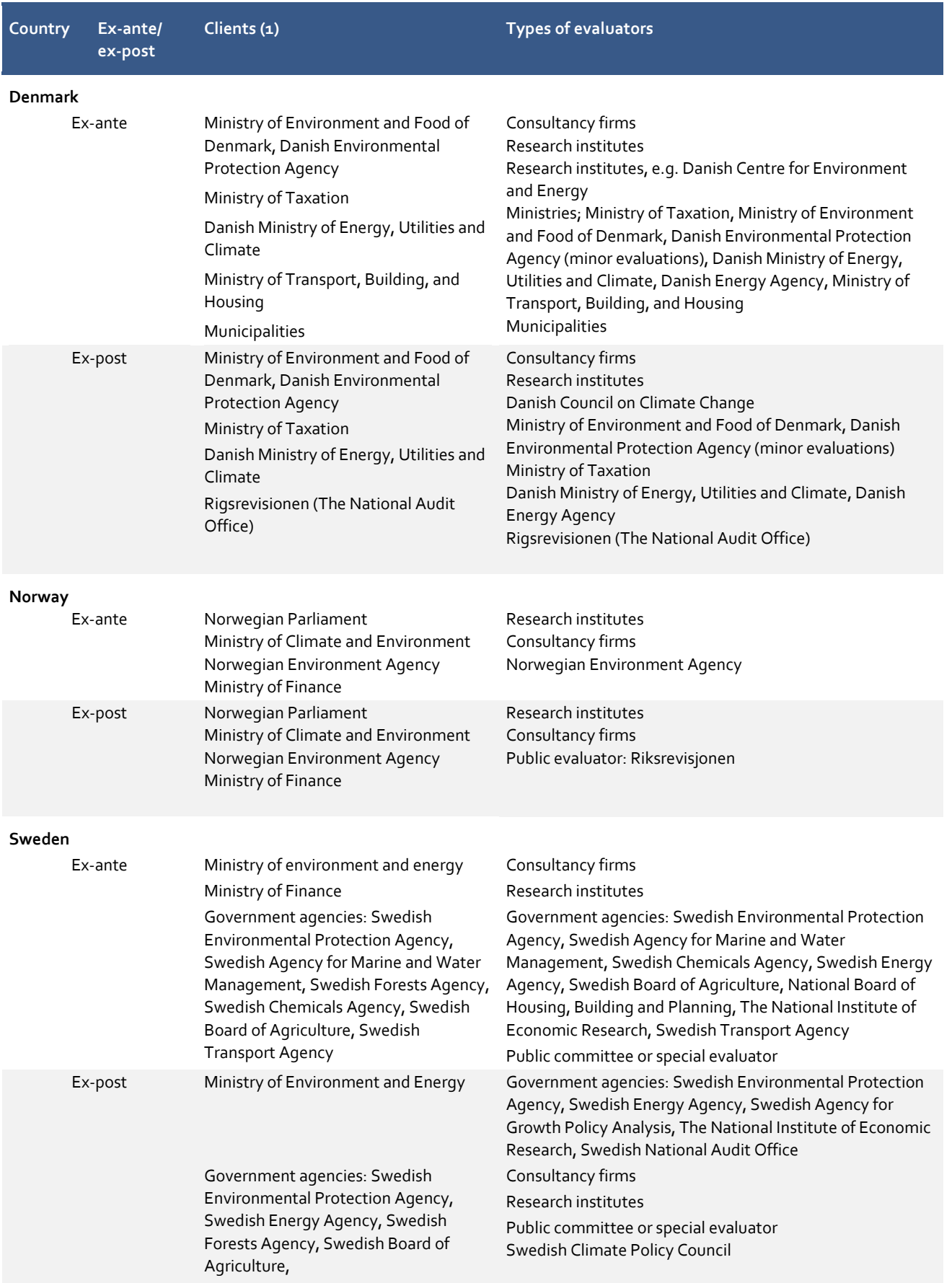




\begin{tabular}{|c|c|c|c|}
\hline Country & $\begin{array}{l}\text { Ex-ante/ } \\
\text { ex-post }\end{array}$ & Clients (1) & Types of evaluators \\
\hline \multicolumn{4}{|l|}{ Finland } \\
\hline \multicolumn{2}{|c|}{ Ex-ante } & $\begin{array}{l}\text { Ministry of Environment } \\
\text { Ministry of Employment and the } \\
\text { Economy } \\
\text { Prime Minister's Office } \\
\text { Ministry of Transport } \\
\text { Ministry of Finance }\end{array}$ & $\begin{array}{l}\text { Ministries/civil servants (incl. inter-ministerial working } \\
\text { group) } \\
\text { External experts (consultancy firms, research Institutes) }\end{array}$ \\
\hline \multicolumn{2}{|c|}{ Ex-post } & $\begin{array}{l}\text { Prime Minister's Office } \\
\text { Ministry of Environment } \\
\text { Ministry of Employment and the } \\
\text { Economy }\end{array}$ & $\begin{array}{l}\text { Ministries/civil servants (incl. inter-ministerial working } \\
\text { group) } \\
\text { External experts (consultancy firms, research Institutes) }\end{array}$ \\
\hline
\end{tabular}

Note: (1) Who is the specific client of the evaluation? Even though it is a ministry that is the client the evaluation can be a requirement from the parliament.

Source: $\quad$ COWI based on written material and stakeholder views.

In Denmark, it is mandatory that legislative proposals and environmental policies, where the impact is expected to be large include an ex-ante evaluation of the consequences for the state, the industry as well as for households, according to "Statsministeriets (1998) cirkulære" (Prime Minister's circular). The level of detail of an ex-ante evaluation depends on the extensiveness of the proposal compared to existing legislation. The ministry formulating the proposal is also responsible for conducting/commissioning the evaluation, hereunder by including other relevant ministries. A number of ministries (Finansministeriet et. al., 2005) have jointly developed a guideline that specifies when, who and what the evaluation must cover (see Section 3.2).

In contrast, while some legislative acts may include a requirement for an ex-post evaluation, there are no general requirements in the Danish legislation to conduct expost evaluations.

In Norway, it is considered important that all governmental initiatives are well founded, and so there must be an ex-ante evaluation as basis for (major) decisions made. The Ministry of Finance has provided instructions for all ministries, where an important principle is that the requirements to the comprehensiveness and thoroughness increase with the scope of the initiative. There are no particular instructions for environmental policies. However, the Ministry of Climate and Environment is responsible for ex-ante evaluations regarding environmental legislation, while including other relevant ministries. The ministry will usually ask the Norwegian Environment Agency for academic advice on specific environmental issues.

Although there are no general requirements or specifications for how to conduct ex-post evaluations, all public authorities must ensure that analyses are conducted to provide information about the efficiency and effectiveness of the initiatives. The extent of a given analysis/evaluation is determined by the initiative's characteristics such as risks and scope.

In Sweden, all legislative proposals must similarly be preceded by an ex-ante evaluation where expected societal consequences are analysed. A ministry can appoint one individual evaluator or a team of evaluators in a so-called "Kommitté" 
(Kommittédirektivet 1998:1475), or ask a public authority to carry out the work (please note that this not imply that the "Kommitte" or public authorithy in question does evaluations only). There are regulations concerning the general content of the analyses but more detailed requirements, e.g. methodological concerns, are typically addressed in the specific instructions to the authority carrying out the evaluation. For example, the Swedish Environmental Protection Agency may specify the objective of an ex-ante evaluation, but not necessarily the method (The Regulatory Impact Assessment Ordinance-SFS 2007:1244).

Since early 2018 , it has been a formal requirement to perform ex-post evaluations for policies in the climate area. This is specified in the Climate Act (Klimatlag 2017:720). While there are no explicit formal requirements to perform ex-post evaluations of policy instruments for other environmentally related policy areas, there is legislation that encourages such exercise. For example, it can be argued that evaluations are needed to be able to comply with the requirements of economising with public funds (Myndighetsförordningen 2007:515 and Budgetlag 2011:203). Also, the Government's instructions to public agencies sometimes include policy evaluation requirements - e.g. the Swedish Environmental Protection Agency (Förordning 2012:989 med instruktion för Naturvårdsverket) and the Swedish Energy Agency (Förordning 2014:520 med instruktion för Statens energimyndighet).

In Finland, both ex-ante and ex-post evaluations are recognised as key tools for ensuring the quality and continuous improvement of legislation and policy-making. Exante evaluations constitute an integral part of new legislative proposals prepared by each ministry, and are regulated by guidelines issued by the Ministry of Justice. ${ }^{6}$ However, ex-ante evaluations of wider policy instruments such as strategies are conducted at inter-ministerial level.

Ex-post evaluations are conducted either based on provisions foreseen in the legislation or on a more ad hoc basis. There is a coordination mechanism in place at centralised level within the Prime Minister's Office. The ultimate responsibility for ensuring the appropriate ex-post evaluation of adopted legislation, however, lies at the level of the individual ministries responsible for the sector concerned.7

A number of initiatives to strengthen evaluation practices have been implemented in recent years. Most recently, in December $2015{ }^{8}$ the Finnish Government established an independent Council of Regulatory Impact Analysis. The Council is responsible for issuing opinions on government proposals and on regulatory impact assessments produced by the competent ministries. It aims at improving the quality of legislative drafting and, in particular, the impact assessment of government proposals.

\footnotetext{
${ }^{6}$ SÄÄDÖSEHDOTUSTEN VAIKUTUSTEN ARVIOINTI, Ohjeet, Oikeusministeriö, Julkaisu 2007:6.

7 Oikeusministeriö, Lainsäädännön prosessiopas (http://lainvalmistelu.finlex.fi/taytantoonpano/\#esittely)

${ }^{8}$ http://vnk.fi/arviointineuvosto
} 
Overall, the above findings point to fairly similar organisational and legislative setups for carrying out environmental policy evaluations in the Nordic countries. Apart from Finland, there are almost only legal requirements to carrying out ex-ante evaluations. The main lessons learnt are:

2. In contrast to Denmark, Norway and Sweden Finland has established ex-post evaluation requirements that mirror ex-ante evaluation requirements, thereby encouraging a consistent policy cycle evaluation process.

3. The Finnish Council of Regulatory Impact Analysis - that seems to be inspired by the European Commission's Regulatory Scrutiny Board - facilitates a formal way of monitoring that evaluations follow a consistent approach and are of good quality.

\subsection{Guidelines}

Table 8 shows, in line with the findings presented in the previous section, that we mostly have identified ex-ante evaluation guidelines in all four Nordic countries.

Table 8: Guidelines for evaluation of environmental policy instruments in the Nordic countries ${ }^{1}$

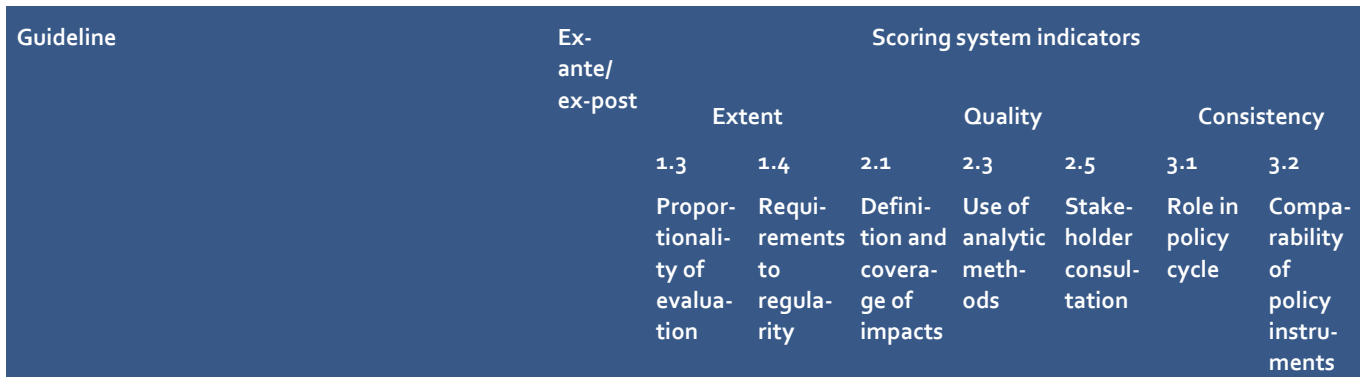

\section{Denmark}

Finansministeriet et.al. (2005), "Vejledning om

konsekvensanalyser" (Ministry of Finance,

"Guidance on impact assessments")

Finansministeriet (2017): "Vejledning i

samfundsøkonomiske konsekvensvurderinger"

(Ministry of Finance, "Guideline for socioeconomic

assessments")

Erhvervsministeriet (2015), "Vejledning om

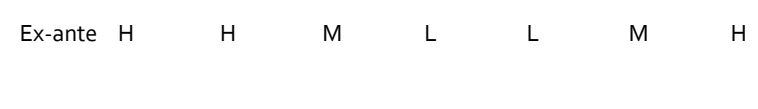

Erhvervsøkonomiske konsekvensvurderinger",

(Ministry of Industry, Business and Financial Affairs,

"Guideline for business economic impact

assessment")

Miljøministeriet (2010), "Samfundsøkonomisk

vurdering af miljøprojekter" (Ministry of

Environment, "Socioeconomic assessment of

environment projects")

Transportministeriet (2015), "Manual for
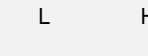

$\mathrm{H}$

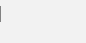

Ex-ante

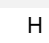

$\mathrm{H}$

M

$\mathrm{H}$

$\mathrm{H}$

$\mathrm{H}$

samfundsøkonomisk analyse på transportområdet"

(Ministry of Transport, Building and Housing,

"Manual for socioeconomic analysis in the field of transport")

Energistyrelsen (2007), "Vejledning I

samfundsøkonomiske analyser på energiområdet",

(The Danish Energy Agency, "Guideline for

socioeconomic assessment in the field of energy") 


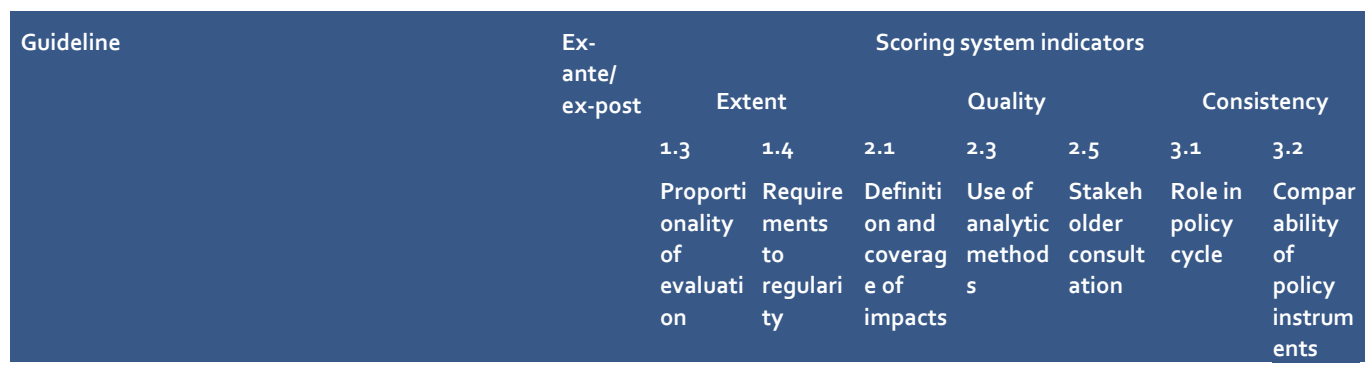

\section{Norway}

Direktoratet for økonomistyring (DFØ) (2016) "Veileder til utredningsinstruksen" (Norwegian Ex-ante $\mathrm{H}$ $\mathrm{H}$ Government Agency for Financial Management (2014) "Guidelines for instructions on ex-ante studies")

Direktoratet for økonomistyring (DFØ) (2014) "Veileder i samfunnsøkonomiske analyser"

(Norwegian Government Agency for Financial Management (2014) "Guidelines for economic analysis")

Direktoratet for økonomistyring (DFØ) (2011)

"Strategisk og systematisk bruk av evaluering $\mathrm{i}$ styringen" (Norwegian Government Agency for Financial Management [2011] "Strategic and systematic use of evaluation in management") Statens Vegvesen 2014 "Håndbok V712 Konsekvensanalyser" (The Norwegian Public Roads Administration 2014 "Handbook V712 Impact assessment on investments")

\section{Sweden}

Naturvårdsverket (2014), "Samhällsekonomiska analyser av miljöprojekt - en vägledning" (Swedish Environmental Protection Agency: "Socioeconomic analyses of environmental projects - a guide") Naturvårdsverket (2003): "Konsekvensanalys steg för steg" (Swedish Environmental Protection Agency, "Socioeconomic impact assessment step by step")

Riksantikvarieämbetet (2008): "Metodhandledning i samhällsekonomisk konsekvensanalys" (Swedish

National Heritage Board, "Methodology in socioeconomic impact assessment")

Trafikverket (2018): "Analysmetod och samhällsekonomiska kalkylvärden för transportsektorn: ASEK 6.1" (Swedish Transport Administration, "Method, pinciples and values for cost-benefit analysis in the transport sector") Konjunkturinstitutet (2011): "Making Climate Policy efficient. Implementing a model for Environmental Policy Efficiency, Environmental economics, M $\mathrm{H} \quad \mathrm{H}$ M M L

Working Paper no 125" (The National Institute of Economic Research)

Energimyndigheten (2015): "Metoder för utvärder-ing Ex-post L av styrmedel - En metautvärdering grundad på litteratur och två fall" (Swedish Energy Agency, "Methods for evaluating policy instruments")

\begin{tabular}{|c|c|c|c|c|c|c|c|}
\hline Ex-ante & L & $M$ & $\mathrm{H}$ & $\mathrm{M}$ & L & L & L \\
\hline Ex-ante & $\mathrm{H}$ & $M$ & $\mathrm{H}$ & $M$ & L & L & M \\
\hline Ex-ante & L & $M$ & $\mathrm{H}$ & $M$ & L & L & L \\
\hline Ex-ante & $\mathrm{H}$ & $M$ & $\mathrm{M}$ & $M$ & L & L & L \\
\hline $\begin{array}{l}\text { Ex- } \\
\text { ante/ } \\
\text { Ex-post }\end{array}$ & L & $\mathrm{H}$ & $M$ & L & $\mathrm{L}$ & $M$ & M \\
\hline
\end{tabular}

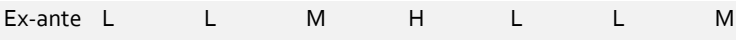




\begin{tabular}{|c|c|c|c|c|c|c|c|c|}
\hline \multirow[t]{4}{*}{ Guideline } & \multirow{4}{*}{$\begin{array}{l}\text { Ex- } \\
\text { antel } \\
\text { ex-post }\end{array}$} & \multicolumn{7}{|c|}{ Scoring system indicators } \\
\hline & & \multicolumn{2}{|c|}{ Extent } & \multicolumn{3}{|c|}{ Quality } & \multicolumn{2}{|c|}{ Consistency } \\
\hline & & 1.3 & 1.4 & 2.1 & 2.3 & 2.5 & 3.1 & 3.2 \\
\hline & & $\begin{array}{l}\text { Proporti } \\
\text { onality } \\
\text { of } \\
\text { evaluati } \\
\text { on }\end{array}$ & $\begin{array}{l}\text { Require } \\
\text { ments } \\
\text { to } \\
\text { regulari } \\
\text { ty }\end{array}$ & $\begin{array}{l}\text { Definiti } \\
\text { on and } \\
\text { coverag } \\
\text { e of } \\
\text { impacts }\end{array}$ & $\begin{array}{l}\text { Use of } \\
\text { analytic } \\
\text { method } \\
\text { s }\end{array}$ & $\begin{array}{l}\text { Stakeh } \\
\text { older } \\
\text { consult } \\
\text { ation }\end{array}$ & $\begin{array}{l}\text { Role in } \\
\text { policy } \\
\text { cycle }\end{array}$ & $\begin{array}{l}\text { Compar } \\
\text { ability } \\
\text { of } \\
\text { policy } \\
\text { instrum } \\
\text { ents }\end{array}$ \\
\hline \multicolumn{9}{|l|}{ Finland } \\
\hline $\begin{array}{l}\text { Oikeusministeriö (2007), "Säädösehdotusten } \\
\text { vaikutusten arviointi" (Finnish Ministry of Justice, } \\
\text { Impact assessment of proposed legislative } \\
\text { measures") }\end{array}$ & Exante & $\mathrm{H}$ & L & $\mathrm{M} / \mathrm{H}$ & M & $\mathrm{L} / \mathrm{M}$ & L & L/M \\
\hline $\begin{array}{l}\text { Ympäristöministeriö (2013), "Menetelmiä ja } \\
\text { tietolähteitä politiikkatoimien vaikutusten } \\
\text { arviointiin" (Finnish Ministry of the Environment, } \\
\text { "Methods and sources for impact assessment of } \\
\text { policies") }\end{array}$ & Ex-ante & M & L & M & $\mathrm{H}$ & $\mathrm{H}$ & L & M \\
\hline $\begin{array}{l}\text { Ympäristöministeriö (2011), "Kestävään kehitykseen } \\
\text { liittyvien vaikutusten ennakkoarviointi } \\
\text { politiikansuunnittelussa ja päätöksenteossa: } \\
\text { Suositus arvioinnin työkaluksi" (Finnish Ministry of } \\
\text { the Environment, "Ex-ante assessment of } \\
\text { sustainable development impacts in policy planning } \\
\text { and decision-making: Recommendation for an } \\
\text { assessment tool") }\end{array}$ & Ex-ante & M & L & $\mathrm{M} / \mathrm{H}$ & $\mathrm{H}$ & L & M & M \\
\hline $\begin{array}{l}\text { Suomen Ympäristökeskus (2006), "Ympäristö- } \\
\text { politiikan taloudellisten vaikutusten arviointi" (Finnish } \\
\text { Environmental Agency, "Assessing the economic } \\
\text { impacts of environmental policy") }\end{array}$ & Ex ante & M & L & M & $\mathrm{H}$ & L & M & $\mathrm{H}$ \\
\hline
\end{tabular}

Note: (1) $H=$ High, $M=$ Medium, $L=$ Low.

Source: COWI.

In Denmark, a number of ministries (Finansministeriet et. al., 2005) have developed a joint, general guideline to carrying out ex-ante evaluations. The guideline underlines that only significant impacts should be covered, and so it scores high with respect to pursuing proportionality of the evaluation. It describes the coverage of impact types for different stakeholder types, but without providing detailed definitions of the impacts. Regarding the use of analytical methods to measure the likely impacts, it mainly relies on other guidelines. The guideline does not explicitly suggest stakeholder consultation as contributor to the evidence base or for the acceptance of the evaluation results. Furthermore, the guideline does not explicitly refer to links to ex-post evaluations of the given policies, and so it does not encourage their consistency within the policy cycle.

In turn, the Ministry of Finance (2017) guideline for ex-ante evaluations goes into much detail when explaining how to use analytical methods - in particular those of a costbenefit analysis and of a cost-effectiveness analysis. Furthermore, it provides details of the definition and coverage of impacts needed to apply these methods - although without explicitly addressing environmental policies and environmental impacts.

The Environmental Protection Agency (2010) provides - while complying with the principles of the Ministry of Finance's guideline - guidance on ex-ante evaluations of environmental projects. The quantification of impacts is here supported by the use of the Danish catalogue of environmental indicator values in evaluations, provided by the 
Ministry of Environment and Food (2015). In addition, the Ministry of Environment and Food (2016) has recently launched an Internal ministerial concept for effect assessments that provides guidance on the use of the effect chain methodology. Currently, this concept is used in connection with ex-ante evaluations. One of the reasons for launching the concept is to ensure that good indicators are identified and introduced at an early stage, including the measurement of baselines, thereby enabling government bodies and others to conduct ex-post evaluations. Most important in this regard is that collection of data to be used in ex-post evaluations may be carried out on a regular basis. The Danish Energy Agency and the Ministry of Transport, Housing and Building have also developed guidelines for ex-ante evaluations that cover impacts related to the climate and environment. Finally, since 2015 is has been mandatory to assess all legislative proposals' impacts on the industry. The Ministry of Industry, Business and Financial Affairs has developed a guideline for this (Erhvervsministeriet, 2015).

In Norway, there is one ex-ante evaluation guideline provided by the Government Agency for Financial Management for the Ministry of Finance, which covers all government authorities from ministries to small agencies. It is complemented by a guideline on how to follow the instructions for different topics. The instructions focus on why and when an evaluation should take place, and on who should be involved. We have therefore given high scores regarding proportionality, regularity, and stakeholder consultation.

The Government Agency also provides a guideline for economic analysis that handles issues such as measuring economic, environmental and healthcare impacts. It is a standard that makes all parameters alike independent of political instrument and topic. Hence, it scores high regarding the definition and coverage of impacts and regarding the use of analytical methods.

For ex-post evaluations, the Government Agency has a small checklist on, as it says, the strategic and systematic use of evaluation in management, Being a short note, it does not go into detail when explaining how to address the central areas, i.e. the extent, the quality, and the consistency of the evaluation. Hence, it generally scores low within our scoring system.

No Norwegian guidelines focus explicitly on environmental policies. However, the Håndbok $V_{712}$ Konsekvensanalyser by the Norwegian Public Roads Administration provides detailed guidance on how to scope environmental impacts. Although the main focus is on public investments, having so comprehensive details, it is also often used for political instrument analysis.

In Sweden, we have identified one ex-post evaluation guideline while the guidance for ex-ante evaluations is more comprehensive. The ex-post evaluation guideline identified, Swedish Energy Agency (Energimyndigheten 2015), is, compared to the other guidelines, fairly specific to the targeted policy area, i.e. energy policy. It scores highest when it comes to specifying regularity requirements, and it provides also good guidance on analytical methods for assessing whether and how a given policy target has been achieved.

Two Swedish ex-ante evaluation guidelines, Naturvårdsverket (2003) and Naturvårdsverket (2014), have a good coverage of environmental impacts. 
Furthermore, both focus on measuring the impacts of policy instruments by applying the cost-benefit analysis method. The first one does this on a more general level while the latter provides a more thorough guideline with many evaluation process details. Swedish Transport Administration (2018) provides a detailed and technical guideline for performing cost-benefit analysis in the transport sector, also including specific values to use for calculations. The guideline does, however, not address the issue of applying the analysis to several different regulations as part of a selection process. In addition, Konjunkturinstitutet (2011) provides evaluation guidelines - ex-ante as well as ex-post - for analysing climate policies.

Finally, there seems to be a tendency that the Swedish ex-ante evaluation guidelines are based on an economic theoretical framework, whereas the sole ex-post evaluation guideline makes use of a theory of change framework from political science.

In Finland, there is a general ex-ante evaluation guidance applicable to all legislative proposals issued by the Government. This guideline has been issued by the Ministry of Justice and has been in force since 2007. It scores high when it comes to guidance regarding the proportionality of the evaluation and has a good account of the impacts to be assessed, covering economic impacts, impacts on the activities of public authorities, environmental impacts and other societal impacts. ${ }^{9}$ However, it is less clear what the requirements are to regularity and what the role of an evaluation is in the policy cycle. Furthermore, it covers legislative measures only, i.e. other policy instruments are not addressed.

While there are some requirements to carrying out ex-post evaluations in Finland, it is somewhat surprising that we have not identified any ex-post evaluation guidelines. However, as shown in Table 8, there are other Finnish guidance documents focusing on the environmental policy domain. While these from the outset look at policies from the ex-ante angle, some of the suggested analytical methods are also considered to be applicable for ex-post evaluations of environmental policies.

We see the main lessons learnt from the above review of the evaluation guidelines as being:

4. Most of the evaluation guidelines in all the Nordic countries are mainly applicable to ex-ante evaluations, and thus do not play much of a role in encouraging comparability between ex-ante and ex-post evaluations - and, in turn, in encouraging consistent policy cycles.

5. All the Nordic countries have more than one (ex-ante) evaluation guideline. The different guidelines shall, however, always be in compliance with the guidelines from the Ministry of Finance. Some of the guidelines focus on the evaluation process, while others focus on the use of analytical methods. Both types of guidance are overall of good quality. 
6. Only few evaluation guidelines explain the use of and the benefit from stakeholder consultation - i.e. how it can contribute to the impact evidence base and how it can help to ensure wide acceptance and, thereby, usability of the evaluation results.

7. There is some variation in how the evaluation guidelines in the different Nordic countries specifically cover the environmental policy domain.

8. In general, the evaluation guidelines pay limited attention to cross-border impacts, although such impacts often can be significant. Furthermore, there is a discrepancy in some of the Nordic countries (e.g., Denmark) between guidelines of ministries of environment and ministries of finance with regard to cross-border impacts. As a rule, guidelines of ministries of finance exclude cross-border impacts.

\subsection{Evaluations}

In this section, we look into 32 already conducted evaluations of environmental policies -i.e. 8 ( 4 ex-post and 4 ex-ante) in each of the four Nordic countries. We do this to look for good, but possibly also less good elements of the evaluations to learn from.

While mapping the environmental policy evaluations carried out in recent years (see Appendix A), we have tried to assess the extent to which evaluations are carried out in the Nordic countries. We do, however, not pretend to have a good estimate of the actual number of evaluations carried out - not least because we do not have much information about the number of evaluations carried out internally in ministries/agencies. Hence, we have not tried to give scores for indicator 1.2 in our scoring system.

We have, however, when consulting stakeholders, inquired about the share of environmental policies being evaluated (indicator 1.1). In general, stakeholders assess that almost $100 \%$ of environmental policies are subject to ex-ante evaluations, not least because it is mandatory to do so. Similarly, most stakeholders assess that only a small share of the environmental policies are subject to ex-post evaluations - our best estimate is $5-10 \%$. However, it has also been noted in the interviews that many evaluations are, in fact, a combination of an ex-ante and ex-post evaluation.

Table 9 contains a summary of our assessments of the quality of 32 already conducted evaluations. For more details, we refer to Appendix B. From the outset, we have assumed that an evaluation is of good quality if it has been conducted according to official evaluation guidelines. We recall here that such guidelines mainly exist for conducting ex-ante evaluations. Hence, particular attention is paid to assessing the quality of the methodologies applied in the ex-post evaluations. We have done this on the basis of our own experience with analysing environmental economic instruments, and of how the methodologies compare with the guidance provided by the BRG, where the toolbox contains a number of evaluations tools, in particular: 
- \#18: The choice of policy instruments - that guides ex-ante evaluations (and policy-makers) when considering alternatives or combinations of legal instruments, voluntary agreements, education and information, and economic instruments to solve a given (environmental) problem;

- \#43: What is an evaluation and when is it required? - that informs the policymakers on the requirements to evaluate in a proportionate way all EU spending and non-spending activities intended to have an impact on society or the economy;

- \#52: Back-to-back evaluations and impact assessments - that guides the policymaking process, both with respect to the coordination of ex-ante and ex-post evaluations, and with respect to the consultation of stakeholders.

Table 9: Quality of already conducted evaluations of environmental policy instruments $(2014-2017)^{1}$

\begin{tabular}{|c|c|c|c|c|c|}
\hline \multirow[t]{3}{*}{ Evaluation } & \multirow{3}{*}{$\begin{array}{l}\text { Ex-ante/ } \\
\text { ex-post }\end{array}$} & \multicolumn{4}{|c|}{ Scoring system indicator } \\
\hline & & 2.1 & 2.3 & 2.5 & 2.6 \\
\hline & & $\begin{array}{l}\text { Definition } \\
\text { and coverage } \\
\text { of impacts }\end{array}$ & $\begin{array}{l}\text { Use of } \\
\text { analytical } \\
\text { methods }\end{array}$ & $\begin{array}{l}\text { Stakeholder } \\
\text { consultation }\end{array}$ & Independency \\
\hline \multicolumn{6}{|l|}{ Denmark } \\
\hline $\begin{array}{l}\text { Danish Council on Climate Change /Klimarådet } \\
\text { (2016): "Afgifter der forandrer - Forslag til } \\
\text { klimavenlige afgiftsomlægninger" ("Charges } \\
\text { that give change - Proposals for climate- } \\
\text { friendly tax changes") }\end{array}$ & $\begin{array}{l}\text { Ex-ante/ } \\
\text { ex-post }\end{array}$ & $\mathrm{H}$ & M & $\mathrm{L}$ & $\mathrm{H}$ \\
\hline $\begin{array}{l}\text { Ministry of Environment and Food of } \\
\text { Denmark/Miljø og Fødevareministeriet } \\
\text { (2017): "Samfundsøkonomisk vurdering af } \\
\text { behandling af imprægneret træaffald" } \\
\text { (Socioeconomic assessment of the treatment } \\
\text { of impregnated wood waste) }\end{array}$ & Ex-ante & $\mathrm{H}$ & $\mathrm{H}$ & $\mathrm{L}$ & $\mathrm{H}$ \\
\hline $\begin{array}{l}\text { Ministry of Taxation/Skatteministeriet (2017): } \\
\text { "Sanering af punktafgifter" (Remediation of } \\
\text { excise duties) }\end{array}$ & $\begin{array}{l}\text { Ex-ante/ } \\
\text { ex-post }\end{array}$ & $M$ & M & M & M \\
\hline $\begin{array}{l}\text { Ministry of Environment/Miljøministeriet } \\
\text { (2013): "Evaluering af vandsektorloven" } \\
\text { (Evaluation of the water sector law) }\end{array}$ & Ex-post & L & $M$ & $\mathrm{H}$ & $\mathrm{H}$ \\
\hline $\begin{array}{l}\text { Danish Council on Climate Change/Klimarådet } \\
\text { (2016): "Midt i en energiomstilling - } \\
\text { udfordringer og løsninger for den danske PSO- } \\
\text { ordning" (In the midst of an energy conversion - } \\
\text { challenges and solutions for the Danish PSO } \\
\text { scheme) }\end{array}$ & $\begin{array}{l}\text { Ex-ante/ } \\
\text { ex-post }\end{array}$ & M & M & $\mathrm{L}$ & $\mathrm{H}$ \\
\hline $\begin{array}{l}\text { Ministry of Environment/Miljøministeriet } \\
\text { (2014), Danish Environmental Protection } \\
\text { Agency: "Evaluering af grønne regnskaber" } \\
\text { (Evaluation of green accounts) }\end{array}$ & Ex-post & L & $\mathrm{L}$ & $\mathrm{H}$ & $\mathrm{H}$ \\
\hline $\begin{array}{l}\text { Ministry of Environment and Food/ Miljø og } \\
\text { Fødevareministeriet (2017): "Effektvurdering af } \\
\text { kemikalieindsatsen 2014-2017" (Effect } \\
\text { assessment of chemical initiatives 2014-2017) }\end{array}$ & Ex-post & $\mathrm{H}$ & $\mathrm{H}$ & M & $\mathrm{H}$ \\
\hline $\begin{array}{l}\text { Niras, DTU Miljø and DAMVAD Analytics } \\
\text { (2017): "Evaluering af Miljøteknologisk } \\
\text { Uviklings- og Demonstrationsprogram" } \\
\text { (Assessment of Environmental Technology } \\
\text { Development and Demonstration Program) }\end{array}$ & Ex-post & $M$ & M & $\mathrm{H}$ & $\mathrm{H}$ \\
\hline
\end{tabular}




\begin{tabular}{|c|c|c|c|c|c|}
\hline \multirow[t]{3}{*}{ Evaluation } & \multirow{3}{*}{$\begin{array}{l}\text { Ex-ante/ } \\
\text { ex-post }\end{array}$} & \multicolumn{4}{|c|}{ Scoring system indicator } \\
\hline & & 2.1 & 2.3 & 2.5 & 2.6 \\
\hline & & $\begin{array}{l}\text { Definition } \\
\text { and coverage } \\
\text { of impacts }\end{array}$ & $\begin{array}{l}\text { Use of } \\
\text { analytical } \\
\text { methods }\end{array}$ & $\begin{array}{l}\text { Stakeholder } \\
\text { consultation }\end{array}$ & Independency \\
\hline
\end{tabular}

\section{Norway}

Østfoldforskning (2016): "Vurdering av

Ex-ante $\quad H$

methods

Stakeholder

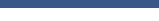

virkemidler for økt utsortering av våtorganisk

avfall og plastemballasje" (Assessment of

policy instruments for increased sorting of

organic waste and plastic packaging)

Norwegian Environment
Agency/Miljødirektoratet (2015): "M-386

Klimatiltak og utslippsbaner mot 2030;

Kunnskapsgrunnlag for lavutslippsutvikling"

("M386 Climate and emissions paths towards

2030; Knowledge base for low-emission

development")

Norwegian Environment Agency/

Miljødirektoratet (2014): "M-133 Faglig

grunnlag for videreutvikling av den nasjonale

og internasjonale klimapolitikken Klimatiltak

mot 2020 og plan for videre arbeid" ("M-133

Academic basis for further development of the

national and international climate policy;

Actions against climate change towards 2020

and plan for further work")

Ministry of Climate and Environment (2015):

"NOU 2015:15 Sett pris på miljøet - Rapport

fra grønn skattekommisjon" [Put a price on the environment - Report from the Green Tax

Commission]

DNV GL AS Maritime (2014) "Miljøvennlige

ferjer: Realisering av null- og

lavutslippsløsninger $\mathrm{i}$ anbudsprosesser for

ferjesamband" (Eco-friendly ferries: Realization

of zero and low-emission solutions in ferry

connection trough tender processes)

Carbon Limits AS, Norsk Energi (2016):

"Konsekvenser av lave kvotepriser i EU ETS"

(Consequences of $\mathrm{CO}_{2}$ emission prices in the $\mathrm{EU}$

ETS)

Riksrevisjonen (2015) "Undersøkelse av

myndighetenes arbeid for å sikre god

luftkvalitet i byområder" (Investigation of

government work to ensure good air quality in urban areas)

Statistics Norway (2015) "Byer og miljø.

Indikatorer for miljøutviklingen $\mathrm{i}$ «Framtidens

byer»" ("Cities and environment. Indicators for

the environmental development in the future

cities")

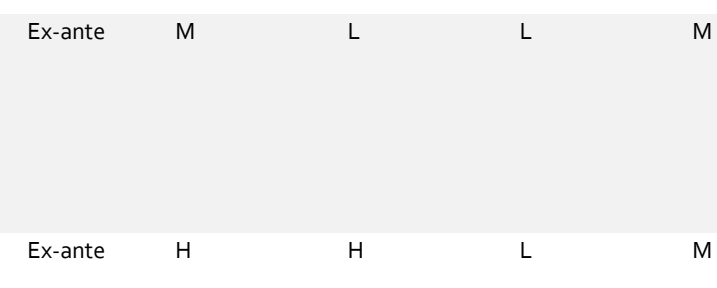

Ex-ante

M

Ex-post

Ex-ante/

Ex-post

M

M

$\mathrm{H}$

M

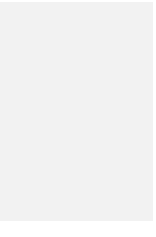

\section{Sweden}

Swedish Environmental Protection Agency

Ex-ante

M

M

M

M

M

$\mathrm{H}$

$\mathrm{H}$

/Naturvårdsverket (2016)*: "Minskad

förbrukning av plastbärkassar" ("Reduced

consumption of plastic carriers")

National Board of Housing, Building and

Planning /Boverket (2015): "Förslag till

utvecklad nationell strategi för

energieffektiviserande renovering" ("Proposals

for developed national strategy for energy-

efficient renovation") 


\begin{tabular}{|c|c|c|c|c|c|}
\hline \multirow[t]{3}{*}{ Evaluation } & \multirow{3}{*}{$\begin{array}{l}\text { Ex-ante/ } \\
\text { ex-post }\end{array}$} & \multicolumn{4}{|c|}{ Scoring system indicator } \\
\hline & & 2.1 & 2.3 & 2.5 & 2.6 \\
\hline & & $\begin{array}{l}\text { Definition } \\
\text { and coverage } \\
\text { of impacts }\end{array}$ & $\begin{array}{l}\text { Use of } \\
\text { analytical } \\
\text { methods }\end{array}$ & $\begin{array}{l}\text { Stakeholder } \\
\text { consultation }\end{array}$ & Independency \\
\hline $\begin{array}{l}\text { Public committee /Kemikalieskatteutredningen } \\
\text { (2015): "Kemikalieskatt, Skatt på vissa } \\
\text { konsumentvaror som innehåller kemikalier" } \\
\text { ("Chemical tax on certain consumer goods } \\
\text { containing chemicals") }\end{array}$ & Ex-ante & $\mathrm{H}$ & $\mathrm{H}$ & M & M \\
\hline $\begin{array}{l}\text { Swedish Agency for Marine and Water } \\
\text { Management /Havs- och vattenmyndigheten } \\
\text { (2013): "Styrmedel för en hållbar åtgärdstakt av } \\
\text { små avloppsanläggningar" ("Policy instruments } \\
\text { for a sustainable pace of action for small } \\
\text { sewage plants") }\end{array}$ & Ex-ante & $\mathrm{H}$ & $\mathrm{H}$ & $\mathrm{H}$ & M \\
\hline $\begin{array}{l}\text { Swedish Forests Agency / Skogsstyrelsen } \\
\text { (2015): "Ekonomiska stöd i skogsbruket" } \\
\text { ("Economic subsidies in the forestry") }\end{array}$ & Ex-post & M & $\mathrm{L}$ & $\mathrm{L}$ & M \\
\hline $\begin{array}{l}\text { Swedish Board of Agriculture /Jordbruksverket } \\
\text { (2016): "Förgröningen i praktiken - kostnader } \\
\text { kontra miljönyttor" ("Greening in practice - } \\
\text { costs and environmental benefits") }\end{array}$ & Ex-post & M & M & $\mathrm{L}$ & M \\
\hline $\begin{array}{l}\text { Sweco energuide AB (2013) "Styrmedels } \\
\text { förutsättningar att styra mot ökad } \\
\text { energieffektivisering - en utvärdering av } 24 \\
\text { styrmedel" ("Possibilities for steering towards } \\
\text { increased energy efficiency - an evaluation of } \\
24 \text { policy instruments") }\end{array}$ & Ex-post & M & $L$ & $\mathrm{~L}$ & M \\
\hline $\begin{array}{l}\text { Public committee Burning taxes } \\
\text { /Förbränningsutredningen (2017) "Brännheta } \\
\text { skatter! Bör avfallsförbränning och utsläpp av } \\
\text { kväveoxider från energiproduktion beskattas?" } \\
\text { ("Should waste incineration and emissions of } \\
\text { nitrogen oxides from energy production be } \\
\text { taxed?") }\end{array}$ & Ex-post & $\mathrm{H}$ & M & M & $\mathrm{H}$ \\
\hline \multicolumn{6}{|l|}{ Finland } \\
\hline $\begin{array}{l}\text { Prime Minister's Office /Valtioneuvoston } \\
\text { kanslia (2017): Energia ja ilmastostrategian } \\
\text { vaikutusarviot: Yhteenvetoraportti (Impact } \\
\text { assessments of the Energy and Climate } \\
\text { strategy: The summary Report) }\end{array}$ & Ex ante & $\mathrm{H}$ & $\mathrm{H}$ & M & $\mathrm{H}$ \\
\hline $\begin{array}{l}\text { Prime Minister's Office/Valtioneuvoston kanslia } \\
\text { (2016): Kohdennetut keinot kierrätyksen } \\
\text { kasvuun. (Policy instruments for increasing } \\
\text { waste recycling) }\end{array}$ & Exante & $\mathrm{H}$ & L/M & $\mathrm{H}$ & $\mathrm{H}$ \\
\hline $\begin{array}{l}\text { Prime Minister's Office /Valtioneuvoston } \\
\text { kanslia (2017): Päästökauppadirektiivin } \\
\text { uudistamisen vaikutukset Suomen } \\
\text { teollisuuteen, energiantuotantoon ja } \\
\text { kansantalouteen. (Impact of the Emissions } \\
\text { Trading Directive on Finnish industry, energy } \\
\text { production and the national economy) }\end{array}$ & Exante & $\mathrm{H}$ & $\mathrm{H}$ & $\mathrm{L}$ & $\mathrm{H}$ \\
\hline $\begin{array}{l}\text { Prime Minister's Office /Valtioneuvoston } \\
\text { kanslia (2016): Yhden luukun periaatteen } \\
\text { toteuttaminen ympäristöasioissa (The } \\
\text { implementation of the one-stop shop principle } \\
\text { in environmental matters) }\end{array}$ & Exante & $\mathrm{H}$ & $L$ & $\mathrm{M} / \mathrm{H}$ & $\mathrm{H}$ \\
\hline $\begin{array}{l}\text { Prime Minister's Office /Valtioneuvoston } \\
\text { kanslia (2016): Biotalous ja cleantech Suomessa } \\
\text { - strategioiden arviointi ja } \\
\text { toimenpidesuositukset. (Bioeconomy and } \\
\text { cleantech in Finland - Assessment of Strategies } \\
\text { and development suggestions.) }\end{array}$ & Expost & $\mathrm{L}$ & M & $\mathrm{H}$ & $\mathrm{H}$ \\
\hline
\end{tabular}




\begin{tabular}{|c|c|c|c|c|c|}
\hline \multirow[t]{3}{*}{ Evaluation } & \multirow{3}{*}{$\begin{array}{l}\text { Ex-ante/ } \\
\text { ex-post }\end{array}$} & \multicolumn{4}{|c|}{ Scoring system indicator } \\
\hline & & 2.1 & 2.3 & 2.5 & 2.6 \\
\hline & & $\begin{array}{l}\text { Definition } \\
\text { and coverage } \\
\text { of impacts }\end{array}$ & $\begin{array}{l}\text { Use of } \\
\text { analytical } \\
\text { methods }\end{array}$ & $\begin{array}{l}\text { Stakeholder } \\
\text { consultation }\end{array}$ & Independency \\
\hline $\begin{array}{l}\text { Prime Minister's Office /Valtioneuvoston } \\
\text { kanslia (2016): Vuoden } 2011 \\
\text { energiaverouudistuksen arviointia (Evaluation } \\
\text { of } 2011 \text { energy tax reform) }\end{array}$ & Expost & M & $\mathrm{H}$ & $\mathrm{L}$ & $\mathrm{H}$ \\
\hline $\begin{array}{l}\text { Prime Minister's Office /Valtioneuvoston } \\
\text { kanslia (2017): Kansallisen } \\
\text { materiaalitehokkuusohjelman arviointi } \\
\text { (Evaluation of Sustainable growth through } \\
\text { material efficiency programme) }\end{array}$ & Expost & $\mathrm{H}$ & $\mathrm{H}$ & M & $\mathrm{H}$ \\
\hline $\begin{array}{l}\text { Ministry of the Environment } \\
\text { /Ympäristöministeriö (2017): Väliarvio Suomen } \\
\text { luonnon monimuotoisuuden suojelun ja } \\
\text { kestävän käytön strategiasta ja } \\
\text { toimintaohjelmasta vuonna } 2016 \text { (A mid-term } \\
\text { review of the Finnish strategy and action plan } \\
\text { for the conservation and sustainable use of } \\
\text { biodiversity in 2016) }\end{array}$ & Expost & M & $L$ & M & $\mathrm{H}$ \\
\hline
\end{tabular}

Note: (1) $\mathrm{H}=$ High, $\mathrm{M}=$ Medium, $\mathrm{L}=$ Low.

* Utvärderingen omfattades av ekonomiskt styrmedel bland flera men ledde till rekommendation om implementering av annat än ekonomiskt styrmedel.

Source: Appendix B.

For Denmark, an initial observation is that several of the selected evaluations have both ex-ante and ex-post elements. This is as such not a problem if it is clear what is what i.e. that the ex-post part concerns the relevance, efficiency and effectiveness of already implemented policies, while the ex-ante part looks into a concrete policy initiative or ways of improving the policy domain in the future and the likely impacts of these. This seems to be the case for most of the included examples, but as discussed further in Chapter 4, the "Effect assessment of chemical initiatives 2014-2017" conducted for the Danish Ministry of Environment and Food by COWI looks at initiatives that have been implemented (i.e. ex-post), but where most of the effects assessed are still to materialise. Hence, somehow an ex-ante evaluation methodology is applied to measure ex-post effects.

The ex-ante evaluations overall score higher than the ex-post evaluations with respect to definitions and coverage of impacts and to the use of analytical methods. We assess this to be a result of the use of the existing evaluation guidelines - that, as shown in the previous section, do not exist for ex-post evaluations. For the two low-scoring expost evaluations, focus is solely on the achievement of specific outputs, while there is only little or no coverage of wider environmental impacts, or socio-economic impacts for that sake. Furthermore, the quantification of impacts stem from theory-based assessments or stakeholder assessments, rather than from the application of genuine quantitative models.

In turn, the ex-post evaluations score overall higher when it comes to stakeholder consultation. Hence, interviews and/or questionnaire surveys are used to obtain stakeholder assessments of the impacts of the given environmental policies. Such 
opportunity to make use of stakeholder assessments as evidence base for estimating likely impacts of future environmental policies has only to a limited degree been exploited by the included ex-ante evaluations. However, we acknowledge that all major policy proposals - that have been subject to ex-ante evaluations - in the further decision-making process will be sent to stakeholders for consultation. In Norway, at least for the included evaluations, there is not the strong tendency found in Denmark that ex-ante evaluations score higher than ex-post evaluations when it comes to the definition and coverage of impacts and to the use of analytical tools. Hence, while the ex-ante evaluations make good use of the available ex-ante evaluations guidelines, the ex-post evaluations also seem to apply recognised analytical methods.

Similar to Denmark, stakeholder consultation is more common within the ex-post evaluations than within the ex-ante evaluations. Hence, interviews with the relevant business sectors have only been carried out as part of assessing the impacts that they already have experienced. And, also similar to Denmark, the evaluations have been carried out by experienced and independent evaluators.

For Sweden, overall, we do not detect differences between the analysed ex-ante and ex-post evaluations when it comes to the definition and coverage of impacts and to the use of analytical methods. Actually, while two of the four ex-ante evaluations, Kemikalieinspektionen (2015) and Havs- och vattenmyndigheten (2013), make good use of the cost-benefit analysis method (although without directly referring to any specific guideline) and have an extensive coverage of impacts, the other two provide only qualitative assessments and cost-efficiency estimates, respectively - also without referring to any evaluation guideline. For example, Boverket (2015) does not even include environmental impacts.

Also for the ex-post evaluations, we see a variety of methods and evaluation designs used. In some cases, focus is on the effectiveness and efficiency of one policy instrument only, while in other cases a methodology is applied that enables the comparison of joint impacts on the targeted area from several policy instruments. There are, however, also examples of ex-post evaluations targeting only a part of the consequences of the policy instrument.

Stakeholder consultation is only made use of to a limited degree - both for the exante and the ex-post evaluations. Only Havs- och vattenmyndigheten (2013) scores high as it made use of a reference group with representatives from relevant industry, research institutes, municipalities and state agencies. The other evaluation reports do not mention any stakeholder consultation.

For Finland, we assess that most of the selected evaluations score high when it comes to one or both of the indicators: definition and coverage of impacts and use of analytical methods. While there is not always a reference to the available ex-ante evaluation guidelines, they seem to have used methods consistent with these. Hence, many of the evaluation results are underpinned by a wide range of analytical methods and tools, including modelling techniques concerning economic and environmental impacts.

Although there are no official ex-post evaluation guidelines, most of the included Finnish ex-post evaluations also make good use of both quantitative and qualitative methods, hereunder statistical analysis and stakeholder consultation. 
Stakeholder consultation is therefore overall used as a way of getting evidence for the evaluations in Finland. For example, two of the ex-ante evaluations have involved the arrangement of workshops with participants from research and industry. One also made use of the open consultation approach via a questionnaire published on the website of the Ministry of Environment.

In Table 9, we did not report on the scores given to the two consistency indicators: role in policy cycle (3.1) and comparability of policy instruments (3.2). The reason is that it has not been easy to assign such scores in a consistent manner (see Appendix B). Hence, overall we do not have a good overview of where, whether or how we can learn from good practices of pursuing policy cycle roles.

Furthermore, it is noted that the scores given to the already-conducted evaluations do not indicate that evaluations of economic instruments overall differ in quality from those of other environmental policy instruments. It follows from Appendix B.

Finally, the main lessons learnt from the analysis of the 32 already conducted evaluations are:

9. Some evaluations have both ex-ante and ex-post elements. This can be problematic for the use of the evaluation results if it is not clear which of the results concern ex-post findings for the relevance, efficiency and effectiveness of policies, and which concern the assessment of the likely impacts of future environmental policies;

10. Apart from Denmark, there is not a strong tendency that ex-ante evaluations define, cover and analyse impacts better than ex-post evaluations although evaluation guidelines almost only are available for ex-ante evaluations;

11. The coverage of impacts in the evaluations, hereunder whether they only cover narrow (e.g. environmental) or also wider impacts on the society, is not always clear - limiting comparisons of the policy instruments being evaluated;

12. Stakeholder consultation is more frequently used within ex-post evaluations than within ex-ante evaluations. For the latter, there seems thus to be missed opportunities regarding obtaining evidence for and regarding securing wide acceptance of the evaluation results. 


\section{Evaluation of a policy instrument}

We have from the 32 already conducted evaluations analysed in the previous chapter selected one for scrutiny. This means that the aim is to assess whether this evaluation could have overcome some of its weaknesses if the evaluator had access to the lessons learnt - presented in the previous chapter.

We have chosen one where COWI was the evaluator - namely, the "Effect assessment of chemical initiatives 2014-2017" conducted for the Danish Ministry of Environment and Food by COWI in 2016. Hence, we allow ourselves to look inwards, while we at the same time have had the opportunity to interview the evaluation team members about their main challenges when conducting the evaluation. From the outset, it should, however, be underlined that we believe that our colleagues have carried out a good evaluation and made skilful use of analytical methods. This said, elements of the evaluation might have been stronger if they had taken into account some of our lessons learnt.

The chemical initiative focuses on three main areas: international influence, toxic products and resources in circuits. In total, a grant of DKK 185 million was allocated to this initiative. Based on extensive data collection through available reports and interviews with the Danish companies, COWI estimated the effect of the effort. The main conclusion from the evaluation was that the environmental and health gains that could be quantified by far outweigh the cost associated with the chemical initiative in the period 2014-2017. This conclusion was reached even though the evaluation only includes a quantitative assessment for a limited part of the effort. The rest of the effects could only be assessed qualitatively.

The evaluation was conducted in close cooperation with the Danish Environmental Protection Agency and the method for estimating the effects is based on the Ministry of Environment and Food's effect chain methodology.

We have, as shown in Table 10, chosen to assess whether or how the evaluation might have benefitted from the 12 lessons learnt - presented in the previous chapter. In the table we have for each lesson learnt assessed its relevance for this specific evaluation (column 2) and described observations (pros and cons) for how the learning point relates to this specific evaluations (column 3 ).

Regarding the organisational (and other) lessons learnt, the main challenge for the evaluation of the chemical initiative was the fact that it had to do an ex-post evaluation before most impacts had materialized. The method used to conduct the evaluation primarily targets ex-ante evaluations and therefore only provides little guidance for how the ex-post evaluation should be conducted. Hence, the evaluation could have benefitted from a more direct discussion of the relevance, efficiency and effectiveness characteristics of the chemical initiative. 
The effects estimated in the evaluation were primarily based on effects estimated in other ex-ante studies and not ex-post studies, since there were none. This does, however, render the final results uncertain. Nevertheless, the results from the analysis provide a good basis for another, future ex-post evaluation, and may inspire similar, future initiatives.

Finally, we envisage that the findings of the evaluation might have had larger impact if more stakeholders had been involved in the evaluation.

Table 10: Lessons learnt for the evaluation "Effect assessment of chemical initiatives 2014-2017"1

No. Lessons learnt Relevance for the specific evaluation Observations
(low, medium, high)

Organisation

$1 \quad$ There are many different clients as well as evaluators, in all four Nordic countries. In itself, this points to a benefit from having common, widelyused evaluation methodologies encouraging that evaluations of different environmental policies are comparable - and so helping choosing the right ones in the future.

2 In contrast to Denmark, Norway and Sweden, Finland has established ex-post evaluation requirements that mirror exante evaluation requirements, thereby encouraging a consistent policy cycle evaluation process.

3 The Finnish Council of Regulatory Impact Analysis - that seems to be inspired by the European Commission's Regulatory Scrutiny Board - facilitates a formal way of monitoring that evaluations follow a consistent approach and are of good quality.

Guidelines

4 Most of the evaluation guidelines in all the Nordic countries are mainly applicable to ex-ante evaluations, and thus do not play much of a role in encouraging comparability between exante and ex-post evaluations - and, in turn, in encouraging consistent policy cycles.

5 All the Nordic countries have more than one (ex-ante) evaluation guideline. The different guidelines shall, however, always be in compliance with the guidelines from the Ministry of Finance. Some of the guidelines focus on the evaluation process, while others focus on the use of analytical methods. Both types of guidance are overall of good quality.

\section{High}

As there is no common requirements for conducting ex-post evaluations the method used in the evaluation was one developed by the ministry.

High

The methodology applied is mainly suitable for an ex-ante evaluation

High

Denmark does not have a formal organisation for monitoring evaluations

Medium

There was not any ex-ante evaluation the ex-post evaluation could use

Low

The used guideline for the effect chain methodology focuses both on process and on method
The developed method seems to be a good method, however the challenge with using this method is that it is difficult to compare the effects found with other evaluations that use a different method.

Denmark doesn't have an official guideline for how to conduct ex-post evaluations. Hence, the evaluation was based on a method that is mainly suitable for ex-ante evaluations and does not describe important factors to evaluate when conducting ex-post evaluations.

If Denmark has had formal board that monitor evaluations similar to the one in Finland, this board may have provided the evaluation team with some best practices for conducting ex- post evaluations that could have benefitted the evaluation. The evaluation was only reviewed by the Ministry of Environment and Food. A formal setup may also have ensured that more stakeholders would have been included in the review of the evaluation's results.

If an ex-ante evaluation had been conducted of the initiative indicators could have been identified and introduced, when defining the baseline and collection of data could then have been conducted on a regularly basis. This would most likely have made it easier to estimate some of the effects in the ex-post evaluation.

Even though the developed method focuses both on process and method the focus is on ex-ante evaluation and not on ex-post evaluations. 
$6 \quad$ Only few evaluation guidelines explain the use of and the benefit from stakeholder consultation -i.e. how it can contribute to the impact evidence base and how it can help to ensure wide acceptance and, thereby, usability of the evaluation results.

7 There is some variation in how the evaluation guidelines in the different Nordic countries specifically cover the environmental policy domain.

8 In general, the evaluation guidelines pay limited attention to cross-border impacts, although such impacts often can be significant. Furthermore, there is a discrepancy in some of the Nordic countries (e.g., Denmark) between guidelines of ministries of environment and ministries of finance with regard to cross-border impacts. As a rule, guidelines of ministries of finance exclude cross-border impacts.

\section{Already conducted evaluations}

9 Some evaluations have both ex-ante and ex-post elements. This can be problematic for the use of the evaluation results if it is not clear which of the results concern ex-post findings for the relevance, efficiency and effectiveness of policies, and which concern the assessment of the likely impacts of future environmental policies.

10 Apart from Denmark, there is not a strong tendency that ex-ante evaluations define, cover and analyse impacts better than ex-post evaluations although evaluation guidelines almost only are available for ex-ante evaluations.

11 The coverage of impacts in the evaluations, hereunder whether they only cover nar-row (e.g. environmental) or also wider impacts on the society, is not always clear - limiting comparisons of the policy instruments being evaluated.

12 Stakeholder consultation is more frequently used within ex-post evaluations than within ex-ante evaluations. For the latter, there seems thus to be missed opportunities regarding obtaining evidence for and regarding securing wide acceptance of the evaluation results.

\section{Medium}

The study did not use an official guideline for how to include stakeholders' views

Medium

Uses former studies to estimate effects

MediumThe study doesn't include crossborder effects

\section{High}

Had to do an ex-post evaluation before most impacts had materialized

\section{Medium}

The evaluation is of high standard

Low

Effects are clearly defined, and the most important impacts are covered.

Low

Stakeholders' views were included in the analysis
The views of stakeholders are included in the analysis. However, the developed interview guide was based on the consultant team's own experience. An official approach for how to include stakeholders might have provided some input for how to include stakeholders also in the review process of the results. The study uses former ex-ante studies conducted in European countries to evaluate the effect of the different initiatives in the initiative.

According to the Danish Ministry of Finance's guideline for evaluations cross-border effects should not be included in evaluations and the study therefore only includes effects in Denmark even though the area is to a large extent regulated through the EU.

The main challenge for the evaluation was that it had to be done before most effects had materialize. However, the results may guide another, future expost evaluation, and may inspire similar, future initiatives.

The evaluation define, cover and analyse impacts thoroughly based on the developed method, hence it confirm the learning point.

The study define effects clearly, but it also concludes that it has been difficult to quantify the environmental effects whereas the health effects have been easier to quantify.

Similarly to other ex-post evaluations, stakeholders' views were included in the analysis when estimating the effects. However, it was only the ministry that commented on the results of the evaluations.

Note: (1) $H=$ High, $M=$ Medium, $L=$ Low.

Source: COWI 


\section{Lessons learnt and recommendations}

We have in the previous chapters already presented a number of lessons learnt from the different parts of the analysis. In this final chapter, we recap on these and provide recommendations for how to make use of the learnings in the future.

Table 11 repeats the three lessons learnt from our analysis of how environmental policy evaluations are organised in the different Nordic countries. They suggest that the current situation - with many different clients as well as evaluators, and it only being mandatory to carry out ex-ante evaluations - gives rise to the risk of evaluation results not being comparable. This is a weakness with respect to having a coherent evidence base of evaluation results that may contribute to effective environmental policies within the countries and across borders. Hence, the weakness is about not having comparable ex-ante and ex-post evaluations and thus not having a consistent policy cycle analysis.

However, there are also benefits from having many evaluators, e.g. a large resource base and the possibility of sharing good evaluation practices. Hence, we do not necessarily recommend changes to this situation. We do see a benefit from more requirements to carrying out (comparable) ex-post evaluations, though. Furthermore, we recommend everyone to keep an eye on the achievements of the new Finnish Council of Regulatory Impact Analysis in getting comparable, high-quality evaluations - and thereby whether the benefits from its activities prove to be higher than the administrative burden from such extra organisational layer.

\section{Table 11: Lessons learnt from organisational setups for evaluations}

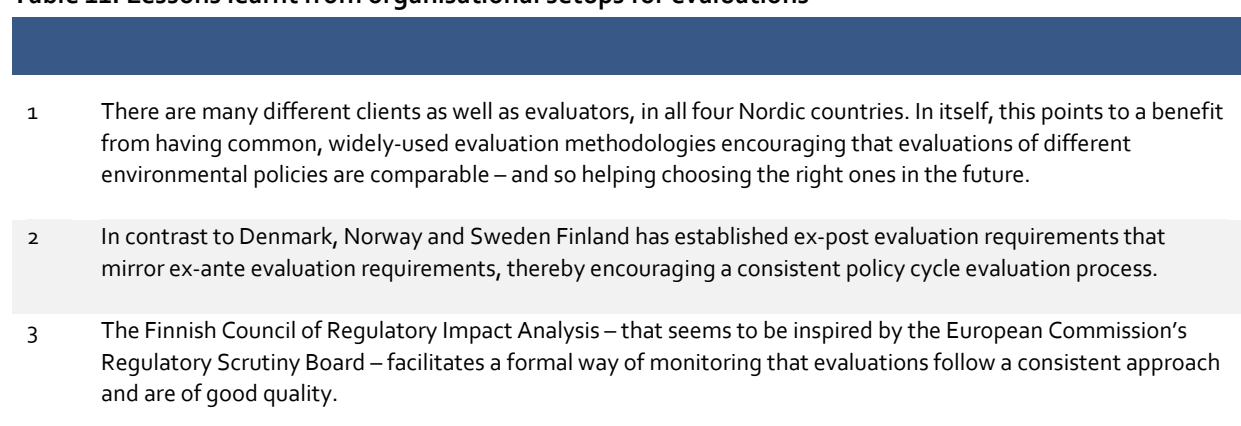

Table 12 shows that the lessons learnt from reviewing the evaluation guidelines made use of in the four Nordic countries follow from the above organisational lessons. Hence, the situation that it is often not mandatory to carry out ex-post evaluations is a reason for low availability of ex-post evaluation guidelines. This underlines the risk of not 
having a coherent evidence base and, in turn, a consistent policy cycle analysis. In order to carry out an ex-post evaluation successfully, it is key that ex-ante guidelines exist and provide a solid foundation, hence it is important that good indicators are identified and introduced at an early stage, i.e. in the ex-ante evaluation when defining the baseline. Most important in this regard is that collection of data to be used in ex-post evaluations may be carried out on a regular basis.

However, we assess that the guidance given to ex-ante evaluations in all four Nordic countries is of good quality. We have learnt that there is a benefit from respecting the different policy cultures, hereunder requirements and ways of carrying out evaluations. Hence, it can be argued that there is little scope for a formal harmonised Nordic approach. This said, we see room for exchange of good practices when it comes to covering the environmental policy domain.

Furthermore, we recommend that the evaluators look for inspiration in the developments made by the European Commission regarding its Better Regulation Guidelines. First, we recommend that the evaluators consider ways - without introducing a new guideline - to provide guidance on how to use the available guidelines in combination, i.e. the guidance on the evaluation process and the guidance on use of analytical evaluation methods. Second, the European Commission has in recent years explored the benefits from consulting stakeholders in the policy cycle. Hence, the current lack of guidance on this in the current Nordic evaluation guidelines could be remedied using this source.

Table 12: Lessons learnt from evaluation guidelines

Most of the evaluation guidelines in all the Nordic countries are mainly applicable to ex-ante evaluations, and
thus do not play much of a role in encouraging comparability between ex-ante and ex-post evaluations - and,
in turn, in encouraging consistent policy cycles.
All the Nordic countries have more than one (ex-ante) evaluation guideline. The different guidelines shall,
however, always be in compliance with the guidelines from the Ministry of Finance. Some of the guidelines
focus on the evaluation process, while others focus on the use of analytical methods. Both types of guidance
are overall of good quality.
Only few evaluation guidelines explain the use of and the benefit from stakeholder consultation -i.e. how it
can contribute to the impact evidence base and how it can help to ensure wide acceptance and, thereby,
usability of the evaluation results.
There is some variation in how the evaluation guidelines in the different Nordic countries specifically cover the
environmental policy domain.
In general, the evaluation guidelines pay limited attention to cross-border impacts, although such impacts
often can be significant. Furthermore, there is a discrepancy in some of the Nordic countries (e.g., Denmark)
between guidelines of ministries of environment and ministries of finance with regard to cross-border impacts.
As a rule, guidelines of ministries of finance exclude cross-border impacts.

A lesson learnt from the analysis of already conducted evaluations is, as shown in Table 13 , that some evaluations contain both ex-post and ex-ante elements. This is as such not a problem if it is clear what is what - i.e. that the ex-post part concerns the relevance, efficiency and effectiveness of already implemented policies, while the ex- 
ante part looks into ways of improving the policy domain in the future and the likely impacts of these. Actually, it is our experience that some ex-post evaluations have sufficient evidence to also underpin recommendations for future policy changes. In other words, an ex-ante evaluation can be spared without breaking the policy cycle. However, this requires of course the existence of an ex-post evaluation guideline to explain how to do this.

Maybe surprisingly, we have not found a strong tendency that the ex-ante evaluations score higher than the ex-post evaluations when it comes to the definition and coverage of impacts and to the use of analytical tools. While this may speak against a strong need for ex-post evaluation guidelines, we do recommend that some of the used, not officially documented, good methodologies are made public - not least to encourage that evaluations results from different evaluations become more comparable.

Furthermore, similar to the analysis of the evaluation guidelines, we find, overall, that there is a lack of consistent coverage of environmental impacts, and a lack of utilising stakeholder consultation as evidence base and for securing wide acceptance of the evaluation results. Hence, we would like to reiterate that the evaluation guidelines could be strengthened in this respect.

Table 13: Lessons learnt from already conducted evaluation

9 Some evaluations have both ex-ante and ex-post elements. This can be problematic for the use of the
evaluation results if it is not clear which of the results concern ex-post findings for the relevance, efficiency and
effectiveness of policies, and which concern the assessment of the likely impacts of future environmental
policies.
Apart from Denmark, there is not a strong tendency that ex-ante evaluations define, cover and analyse
impacts better than ex-post evaluations although evaluation guidelines almost only are available for ex-ante
evaluations.
The coverage of impacts in the evaluations, hereunder whether they only cover narrow (e.g. environmental) or
also wider impacts on the society, is not always clear - limiting comparisons of the policy instruments being
evaluated.
Stakeholder consultation is more frequently used within ex-post evaluations than within ex-ante evaluations.
For the latter, there seems thus to be missed opportunities regarding obtaining evidence for and regarding
securing wide acceptance of the evaluation results.

Finally, the lessons from the previous chapter from looking into whether a given already-conducted evaluation could have been done better confirm the relevance of the above learning points and recommendations. 


\section{Sammendrag}

Denne rapport præsenterer en analyse af den betydning, evalueringer har for udformningen af miljøpolitikken i fire nordiske lande (Danmark, Finland, Norge og Sverige), og diskuterer, hvorledes evalueringerne af tiltag og instrumenter inden for miljøpolitikken kan blive (endnu) bedre tilrettelagt og gennemført, så de bidrager til udformningen af på én gang efficiente (omkostningseffektive) og effektive miljøpolitiske tiltag og instrumenter. Fokus $\mathrm{i}$ analysen er på evalueringer af miljøpolitiske tiltag, der indeholder økonomiske instrumenter såvel som politiske instrumenter.

Rapporten er udarbejdet af COWI A/S på vegne af Miljø- og Økonomigruppen i Nordisk Ministerråd. Miljø- og Økonomigruppen er en tværsektoriel gruppe med et mandat, som godkendes af både miljøsektoren og finanssektoren ved Nordisk Ministerråd.

Analysen ser på både ex-ante- og ex post-evalueringer, dvs. vurderinger af miljøpolitiske tiltag og instrumenter før henholdsvis efter deres gennemførelse (jf. Tabel 1 for en mere detaljeret definition af ex-ante- og ex-post-evalueringer).

Tabel 1: Ex-ante- og ex-post-evalueringer, Definitioner

\begin{tabular}{|c|c|}
\hline Tyре & Definition \\
\hline Ex-ante-evaluering & $\begin{array}{l}\text { Ex-ante-evalueringer (1) forklarer den logiske sammenhæng mellem problemet, dets } \\
\text { underliggende årsager, målene, og mulige politiske tiltag til løsning af problemet. De } \\
\text { beskriver de sandsynlige effekter af tiltagene, dvs. hvem der bliver påvirket af dem og } \\
\text { hvordan. } \\
\text { Ex-ante-evalueringer sammenligner de politiske tiltag med hensyn til deres vurderede } \\
\text { økonomiske, sociale, og miljømæssige effekter. }\end{array}$ \\
\hline Ex-post-evaluering & $\begin{array}{l}\text { Ex-post-evalueringer (2) informerer regelmæssigt (3) politikere om eksisterende politiske } \\
\text { tiltag og sikrer, at der findes relevant evidens til brug ved forberedelse af nye tiltag } \\
\text { ("evaluér først"-princippet). } \\
\text { Ex-post-evalueringer skal som et minimum vurdere effektivitet, omkostningseffektivitet, } \\
\text { relevans og sammenhæng med andre politiske tiltag. Vurderingerne skal altid forsøge at } \\
\text { indeholde kvantificeringer af lovgivningsmæssige omkostninger og gevinster og skal } \\
\text { beskrive administrativt tunge eller komplekse aspekter af lovgivningen og dens } \\
\text { implementering. } \\
\text { Ex-post-evalueringer skal vurdere alle væsentlige økonomiske, sociale, og miljømæssige } \\
\text { effekter. }\end{array}$ \\
\hline
\end{tabular}

Noter: (1) Ex-ante-evalueringer kaldes også effektvurderinger (på engelsk "impact assessments") i BRG.

(2) Ex-post-evalueringer omtales ofte evalueringer, slet og ret.

(3) Ideelt bør ex-post evalueringer udføres regelmæssigt, men i praksis udføres de ofte mere ad-hoc.

Source: COWI - inspireret af EU Kommissionens såkaldte "Better Reguation Guidelines" (BRG; for information vedrørende disse, se: https://ec.europa.eu/info/better-regulation-toolbox_en). 
I analysen ser vi på tre aspekter af ex-ante- og ex-post-evalueringer:

- Organisering: Hvordan er evalueringerne af miljøpolitiske tiltag og instrumenter organiseret i de nordiske lande, dvs. hvem er aktørerne, og hvilke krav stilles der til evalueringerne (hvornår og hvordan skal de gennemføres)?

- Vejledninger: Hvilke typer af vejledninger for gennemførelsen af ex-ante- og expost-evalueringer findes der?

- Specifikke evalueringer: Vi ser på 32 allerede gennemførte evalueringer miljøpolitiske tiltag og instrumenter (fire ex-ante- og fire ex-post-evalueringer $\mathrm{i}$ hvert af de fire lande omfattet af analysen). Det gør vi for at indfange gode og også mindre gode eksempler, som der på forskellig vis kan tages ved lære af.

For at undersøge disse tre aspekter har vi udarbejdet en række undersøgelsesspørgsmål, udviklet et scoringssystem og gennemført en række interviews

På baggrund af den foretagne analyse har vi identificeret en række læringspunkter for de tre undersøgte aspekter, jf. Tabel 2. Baseret på læringspunkterne har vi opstillet en række anbefalinger for, hvordan evalueringer af miljøpolitiske tiltag kan forbedres.

Overordnet viser analysen, at de nordiske lande alle som én har et velforankret og klart organisatorisk setup for gennemførelsen af ex-ante-evalueringer af miljøpolitiske tiltag og instrumenter, mens der er plads til forbedring, når det handler om ex-postevalueringer. Kun Finland har et krav og en proces for gennemførelsen af ex-postevalueringer af miljøpolitiske tiltag og instrumenter. Med hensyn til organisering anbefaler vi derfor, at:

- Evaluatorer i Danmark, Norge og Sverige henter værdifuld inspiration i Finland, når det handler om at opstille krav til ex-post-evalueringer, der afspejler kravene til ex-ante-evalueringer, og som på den måde sikrer en konsistent evalueringsproces fra start til slut.

I alle nordiske lande er det et krav, at der gennemføres ex-ante-evalueringer for miljøpolitiske tiltag, som forventes at have en stor effekt og der eksisterer vejledninger herfor; vedledningerne fortæller, hvordan ex-ante-evalueringerne skal gennemføres. Der er dog nogle forskelle landene imellem med hensyn til hvordan og i hvilket omfang disse vejledninger undersøger de miljøpolitiske tiltag. Med hensyn til vejledninger for udarbejdelse af evalueringer har vi følgende anbefalinger:

- Der synes at være grobund for en øget udveksling af gode eksempler. For eksempel kan brugen af det danske katalog over miljøøkonomiske nøgletal i evalueringer og den svenske vejledning vedrørende evaluering af miljøpolitiske tiltag tjene som inspiration for andre lande. 
- Vejledninger for ex-ante evalueringer skal sikre et solidt fundament for ex-post evalueringer. For at udarbejde en god ex-post evaluering er det vigtigt, at gode indikatorer identificeres på et tidligt stadie, dvs. i forbindelse med ex-anteevalueringen. Kun på denne måde kan det sikres, at data, som skal anvendes i expost-evalueringen, indsamles regelmæssigt.

- Der et behov for at udarbejde særlige vejledninger for gennemførelsen af ex-postevalueringer. Disse vejledninger kan med fordel trække på EU Kommissionens såkaldte "Better Regulation Guidlines" (BRG) og dets tilhørende værktøjskasse. ${ }^{10}$

Selv om der ikke er krav eller vejledninger for, hvordan ex-post evalueringer skal gennemføres, har vi i analysen ikke fundet nogen stærk tendens for at ex-ante evalueringer er bedre end ex-post evalueringer med hensyn til definition og estimering af effekter samt brugen af analytiske metoder. Analysen af de allerede gennemførte evalueringer viser dog, at det ikke altid er klart, hvilke effekter som er inkluderet i evalueringen samt hvilke begrænsninger der er i forhold til estimering af effekterne. Herudover viser studiet af de specifikke evalueringer, at interessenter kun inddrages $i$ begrænset omfang. Baseret på studiet af de gennemførte evalueringer har vi følgende anbefalinger:

- De brugte, ikke officielt dokumenterede og gode metoder bør offentliggøres ikke mindst for at sikre at resultater fra forskellige evalueringer bliver sammenlignelige.

- Anbefalinger og best practices for at involvere interessenter skal inkluderes $\mathrm{i}$ evaluerings-vejledninger. 
1. I de fire nordiske lande er der mange forskellige aktører, heriblandt kunder og evaluatorer. Det peger i sig selv på, at det er en fordel $i$ hvert land at have fælles, let tilgængelige evalueringsmetodikker, så evalueringer af forskellige miljøpolitikker er sammenlignelige. Herved vil man bedre kunne udforme fremtidige miljøpolitiske tiltag og instrumenter.

2. I modsætning til Danmark, Norge og Sverige har Finland opstillet krav til ex-post evalueringer. Kravene afspejler kravene til ex-ante evalueringer, så der sikres konsistens mellem ex-ante- og ex-post-evalueringer.

3. Det finske "Council of Regulatory Impact Analysis", der synes inspireret af EU Kommissionens "Regulatory Scrutiny Board", facilitere en mere formel proces til sikring af, at evalueringerne følger en konsistent metode og er af en høj kvalitet.

Vejledninger

4. Hovedparten af evaluerings-vejledningerne i de nordiske lande vedrører ex-ante evalueringer og spiller således ikke en stor rolle med hensyn til at fremme sammenligneligheden mellem ex-ante og ex-post evalueringer og dermed fremme en konsistent proces for gennemførelsen af evalueringer.

5. Alle de nordiske lande har mere end en vejledning vedrørende ex-ante-evalueringer. De forskellige vejledninger skal dog være i overensstemmelse med finansministeriernes vejledning for evalueringer. Nogle af vejledningerne fokuserer på evalueringsprocessen, mens andre fokuserer på de analytiske metoder. Begge typer af vejledninger er af høj kvalitet.

6. Kun få evalueringer beskriver, hvordan interessenter kan inddrages, samt fordelene herved - med andre ord, hvordan interessenter kan bidrage til effektvurderinger samt hjælpe med at sikre en bred accept af evalueringen og dermed brugen af evalueringsresultaterne.

7. Der er en vis variation i, hvordan evaluerings-vejledningerne i det nordiske lande undersøger de miljøpolitiske tiltag.

8. Generelt lægger evaluerings-vejledningerne begrænset vægt på de grænseoverskridende effekter, selv om disse effekter ofte er betydelige. Desuden er der i nogle af de nordiske lande (f.eks. Danmark) en uoverensstemmelse mellem vejledningerne fra henholdsvis miljøministerierne og finansministerierne med hensyn til, hvordan grænseoverskridende effekter skal medtages. Finansministerierne ekskluderer som hovedregel grænseoverskridende effekter.

\section{Gennemførte evalueringer}

9. Nogen evalueringer har både ex-ante- og ex-post-elementer. Dette kan være problematisk i forhold til anvendelse af resultaterne, såfremt det ikke er klart, hvilke resultater der vedrører en vurdering af de mulige fremtidige virkninger af de miljøpolitiske tiltag og instrumenter (ex-ante), og hvilke resultater der vedrører efficiens og effektivitet af samme.

10. Med undtagelse af Danmark synes det ikke at være sådan, at ex-ante-evalueringer omhandler effekter og bruger analytiske metoder bedre end ex-post evalueringer, selv om der næsten kun er evaluerings-vejledninger for exante evalueringer.

11. Nogle evalueringer omhandler kun miljøeffekter, mens andre også omhandler effekter på samfundet. Dette begrænser muligheden for at sammenligne evalueringer af politiske instrumenter.

12. Interessentinddragelse anvendes oftere i ex-post-evalueringer end i ex-ante-evalueringer. Sidstnævite type af evalueringer forpasser dermed muligheden for at styrke indsamlingen af robuste data samt sikre accept af resultaterne. 


\section{Appendix A: Mapping of evaluations}

Table A-1: Environmental policy evaluation in Denmark, Norway, Sweden, and Finland, 2011-2017- Non-exhaustive list

\begin{tabular}{|c|c|c|}
\hline Year & Client & Title and link \\
\hline \multicolumn{3}{|l|}{ Denmark } \\
\hline Ongoing & $\begin{array}{l}\text { DCE - Nationalt Center for Miljø } \\
\text { og Energi [Danish Centre for } \\
\text { Environment and Energy] }\end{array}$ & $\begin{array}{l}\text { Evaluering af effekterne af den omlagte pesticidafgift [Evaluation of the effects of the } \\
\text { restructured pesticide tax] http://pure.au.dk/portal/da/projects/evaluering-af- } \\
\text { effekterne-af-den-omlagte-pesticidafgift(292a1638-d6da-49eb-a5fc- } \\
\text { d4ede6179(5d).html }\end{array}$ \\
\hline 2017 & $\begin{array}{l}\text { Miljø- og Fødevareministeriet, } \\
\text { Miljøstyrelsen [Ministry of } \\
\text { Environment and Food of } \\
\text { Denmark, Danish Environmental } \\
\text { Protection Agency] }\end{array}$ & $\begin{array}{l}\text { Samfundsøkonomisk vurdering af behandling af imprægneret træaffald } \\
\text { [Socioeconomic assessment of the treatment of impregnated wood waste] } \\
\text { http://www2.mst.dk/Udgiv/publikationer/2017/05/978-87-93529-95-3.pdf }\end{array}$ \\
\hline 2017 & $\begin{array}{l}\text { Miljø- og Fødevareministeriet } \\
\text { [Ministry of Environment and } \\
\text { Food] }\end{array}$ & $\begin{array}{l}\text { Effektvurdering af kemikalieindsatsen } 2014-2017 \text { [Effect assessment of chemical } \\
\text { initiatives 2014-2017] http://www2.mst.dk/Udgiv/publikationer/2017/06/978-87-93614- } \\
\text { 02-4.pdf }\end{array}$ \\
\hline 2016 & $\begin{array}{l}\text { Klimarådet [Danish Council on } \\
\text { Climate Change] }\end{array}$ & $\begin{array}{l}\text { Effektive veje til drivhusgasreduktion i landbruget [Effective ways to reduce } \\
\text { greenhouse gas emissions in agriculture] } \\
\text { http://www.klimaradet.dk/da/nyheder/landbrugets-groenne-omstilling-kraever-bedre- } \\
\text { regulering }\end{array}$ \\
\hline 2016 & $\begin{array}{l}\text { Klimarådet [Danish Council on } \\
\text { Climate Change] }\end{array}$ & $\begin{array}{l}\text { Afgifter der forandrer - Forslag til klimavenlige afgiftsomlægninger [Charges that give } \\
\text { change - Proposals for climate-friendly tax changes] } \\
\text { http://www.klimaradet.dk/da/rapporter/afgifter-der-forandrer }\end{array}$ \\
\hline 2016 & $\begin{array}{l}\text { Klimarådet [Danish Council on } \\
\text { Climate Change] }\end{array}$ & $\begin{array}{l}\text { Midt i en energiomstilling - udfordringer og løsninger for den danske PSO-ordning [In } \\
\text { the midst of an energy conversion - challenges and solutions for the Danish PSO } \\
\text { scheme] http://www.klimaradet.dk/da/analyser/midt-i-en-energiomstilling- } \\
\text { udfordringer-og-loesninger-den-danske-pso-ordning }\end{array}$ \\
\hline 2015 & $\begin{array}{l}\text { Miljøstyrelsen [Danish } \\
\text { Environmental Protection } \\
\text { Agency] }\end{array}$ & $\begin{array}{l}\text { Resultat af den internationale evaluering af grundvandsbeskyttelsen ift. sprøjtemidler } \\
\text { [Review of the Danish risk assessment methodology regarding leaching to } \\
\text { groundwater] http://mst.dk/service/nyheder/nyhedsarkiv/2015/maj/internationale- } \\
\text { evaluering-af-grundvandsbeskyttelsen/ }\end{array}$ \\
\hline 2015 & $\begin{array}{l}\text { Klimarådet [Danish Council on } \\
\text { Climate Change] }\end{array}$ & $\begin{array}{l}\text { Omstilling med omtanke - Status og udfordringer for dansk klimapolitik [Change with } \\
\text { care - Status and challenges for Danish climate policy } \\
\text { http://www.klimaradet.dk/da/rapporter/omstilling-med-omtanke }\end{array}$ \\
\hline 2014 & $\begin{array}{l}\text { Miljøministeriet, Miljøstyrelsen } \\
\text { [Ministry of Environment, } \\
\text { Danish Environmental } \\
\text { Protection Agency] }\end{array}$ & $\begin{array}{l}\text { Evaluering af grønne regnskaber [Evaluation of green accounts] } \\
\text { http://www.ft.dk/samling/20141/almdel/miu/bilag/27/1412964.pdf }\end{array}$ \\
\hline 2013 & $\begin{array}{l}\text { Miljøministeriet [Ministry of } \\
\text { Environment] }\end{array}$ & $\begin{array}{l}\text { Evaluering af vandsektorloven [Evaluation of the water sector law] } \\
\text { http://eng.svana.dk/media/203683/evalueringafvandsektorlovenendeligrapport.pdf }\end{array}$ \\
\hline 2012 & $\begin{array}{l}\text { DCE - Nationalt Center for Miljø } \\
\text { og Energi [Danish Centre for } \\
\text { Environment and Energy] }\end{array}$ & $\begin{array}{l}\text { Optimising the effect of policy instruments: A study of farmers' decision rationales and } \\
\text { how they match the incentives in Danish pesticide policy } \\
\text { https://www.researchgate.net/publication/254303975_Optimising_the_effect_of_polic } \\
\text { y_instruments_A_study_of_farmers'_decision_rationales_and_how_they_match_the_ } \\
\text { incentives_in_Danish_pesticide_policy }\end{array}$ \\
\hline \multicolumn{3}{|l|}{ Norway } \\
\hline 2016 & Statistics Norway & $\begin{array}{l}\text { "Evaluering av virkemidler for å fremme energieffektivisering" } \\
\text { https://www.ssb.no/energi-og-industri/artikler-og-publikasjoner/evaluering-av- } \\
\text { virkemidler-for-a-fremme-energieffektivisering }\end{array}$ \\
\hline 2015 & Statistics Norway & $\begin{array}{l}\text { "Byer og miljø Indikatorer for miljøutviklingen i "Framtidens byer" } \\
\text { https://www.ssb.no/natur-og-miljo/artikler-og- } \\
\text { publikasjoner/_attachment/225738?_ts=14d1deb5aa8 }\end{array}$ \\
\hline 2016 & Norwegian Environment Agency & $\begin{array}{l}\text { "Vurdering av virkemidler for økt utsortering av våtorganisk avfall og plastemballasje" } \\
\text { http://www.miljodirektoratet.no/no/Publikasjoner/2016/Mars-2016/Vurdering-av- } \\
\text { virkemidler-for-okt-utsortering-av-vatorganisk-avfall-og-plastemballasje/ }\end{array}$ \\
\hline
\end{tabular}




\begin{tabular}{|c|c|c|}
\hline Year & Client & Title and link \\
\hline 2014 & Nordic Council of Ministers & $\begin{array}{l}\text { "Economic Policy Instruments for Plastic Waste - A review with Nordic perspectives" } \\
\text { http://www.norden-ilibrary.org/environment/economic-policy-instruments-for-plastic- } \\
\text { waste_tn2014-569 }\end{array}$ \\
\hline 2013 & Electronics industry & $\begin{array}{l}\text { "Innsamling av småelektronikk og elektronikkavfall. Virkemidler og miljøeffekter" } \\
\text { https://vista-analyse.no/site/assets/files/5828/va-rapport_34-2012_ee- } \\
\text { avfall_milj_og_virkemidler.pdf }\end{array}$ \\
\hline 2011 & CICERO & $\begin{array}{l}\text { "Vurderinger av norsk klimapolitikk - En syntese av fire internasjonale rapporter" } \\
\text { http://www.cicero.vio.no/no/publications/internal/128 }\end{array}$ \\
\hline 2011 & Nordic Council of Ministers & $\begin{array}{l}\text { "Voluntary Agreements and Environmental Labelling in the Nordic Countries" } \\
\text { http://www.norden-ilibrary.org/environment/voluntary-agreements-and- } \\
\text { environmental-labelling-in-the-nordic-countries_tn2011-538 }\end{array}$ \\
\hline 2011 & OECD & $\begin{array}{l}\text { "OECD Environmental Performance Reviews: Norway 2011" http://www.oecd- } \\
\text { ilibrary.org/environment/oecd-environmental-performance-reviews-norway- } \\
2011 \text {-9789264098473-en }\end{array}$ \\
\hline
\end{tabular}

\section{Sweden}

2017 Swedish Government

2016 Swedish Government
$2016 \quad$ Swedish Board of Agriculture

2015 National Board of Housing, Building and Planning

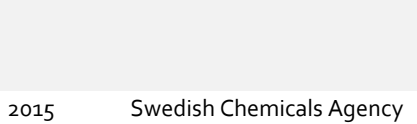

$\begin{array}{ll}2015 & \text { Swedish Forests Agency } \\ 2013 & \text { Swedish Agency for Marine and } \\ \text { Water Management }\end{array}$

2013 Sweco energuide $A B$
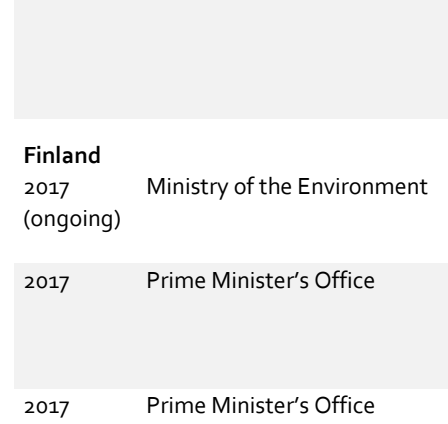

"Brännheta skatter! Bör avfallsförbränning och utsläpp av kväveoxider från energiproduktion beskattas?" http://www.regeringen.se/rattsdokument/statensoffentliga-utredningar/2017/11/sou-201783/ "Minskad förbrukning av plastbärkassar" http://www.naturvardsverket.se/upload/miljoarbete-i-samhallet/miljoarbete-isverige/regeringsuppdrag/2016/rapport-plastbarkassar-v16.pdf Förgröningen i praktiken - kostnader kontra miljönyttor ["Greening in practice - costs and envi-ronmental benefits"]

http://www2.jordbruksverket.se/download/18.36b894651576a404eo2f139/1474966108 018/ra16_18.pdf

Förslag till utvecklad nationell strategi för energieffektivise-rande renovering [Proposals for developed national strategy for energy-efficient renovation] https://www.boverket.se/sv/om-boverket/publicerat-avboverket/publikationer/2015/utvecklad-nationell-strategi-for-energieffektiviseranderenovering/

Kemikalieskatt, Skatt på vissa konsumentvaror som innehåller kemikalier ["Chemical tax, Tax on certain consumer goods containing chemicals"]

http://www.google.se/url?sa=t\&rct=j\&q=\&esrc=s\&source=web\&cd=3\&cad=rja\&uact=8 \&ved=oahUKEwjqj4nS4v3YAhWNYIAKHZM_AJYOFggzMAI\&url=http\%3A\%2F\%2Fww w.regeringen.se $\% 2 \mathrm{~F}_{4}$ gbbof\% ${ }_{2} \mathrm{~F}$ contentassets $\% 2 \mathrm{~F}_{4} \mathrm{a} 79 \mathrm{~d} 2 \mathrm{C}_{3} 6_{4} 15435 \mathrm{fb}_{2} \mathrm{c}_{2} \mathrm{O} 2 \mathrm{dbf}_{54} \mathrm{bob}$ da\%2Fkemikalieskatt--skatt-pa-vissa-konsumentvaror-som-innehallerkemikalier\&usg=AOvVaw1UilgNaXGWJ_4Mg-6c5hr1

Ekonomiska stöd i skogsbruket [Economic subsidies in the forestry] https://www.ivl.se/download/18.4b1c947d15125e72dda144d/1449742309518/C132.pdf Styrmedel för en hållbar åtgärdstakt av små avloppsanlägg-ningar ["Policy instruments for a sustainable pace of action for small sewage plants"] https://www.havochvatten.se/download/18.16a42a771405a5eg6072fe6/1379305996556 /reguppdrag-slutrapport-styrmedel-hallbar-atgardstakt-enskilda-avlopp.pdf Styrmedels förutsättningar att styra mot ökad energieffektivise-ring - en utvärdering av 24 styrmedel [Possibilities for steering towards increased energy efficiency - an evaluation of 24 policy instruments]

http://extra.lansstyrelsen.se/energi/SiteCollectionDocuments/Uppföljning/En\%2outvär dering\%20av\%2024\%20styrmedel_Sweco_\%2020140218.pdf

Jäteveden sisältämän fosforin talteenotto ja kierrättäminen. [Recovery and recycling of phosphorus from wastewater] http://tietokayttoon.fi/hankkeet/hanke-esittely/lasset_publisher/jateveden-sisaltaman-fosforin-talteenotto-ja-kierrattaminen Kansallisen materiaalitehokkuusohjelman arviointi [Evaluation of National Material Efficiency Programme] http://tietokayttoon.fi/documents/10616/3866814/64_Kansallisen+materiaalitehokkuu sohjelman+arviointi.pdf/9416e1e8-3afa-417c-ba47-468fb55a0707?version=1.0 Päästökauppadirektiivin uudistamisen vaikutukset Suomen teollisuuteen, energiantuotantoon ja kansantalouteen. [Impact of the Emissions Trading Directive on Finnish industry, energy production and the national economy] http://tietokayttoon.fi/hankkeet/hanke-esittely/lasset_publisher/paastokauppadirektiivin-uudistamisen-vaikutukset-suomenteollisuuteen-energiantuotantoon-ja-kansantalouteen 


\begin{tabular}{|c|c|c|}
\hline Year & Client & Title and link \\
\hline 2017 & Ministry of the Environment & $\begin{array}{l}\text { Väliarvio Suomen luonnon monimuotoisuuden suojelun ja kestävän käytön } \\
\text { strategiasta ja toimintaohjelmasta vuonna } 2016 \text { [A mid-term review of the Finnish } \\
\text { strategy and action plan for the conservation and sustainable use of biodiversity in } \\
2016 \text { ] } \\
\text { https://julkaisut.valtioneuvosto.fi/bitstream/handle/10024/79871/YMra_14_2017.pdf?se } \\
\text { quence=1 }\end{array}$ \\
\hline 2017 & Prime Minister's Office & $\begin{array}{l}\text { Energia ja ilmastostrategian vaikutusarviot: Yhteenvetoraportti [Impact assessments } \\
\text { of the Energy and Climate strategy: The summary Report] } \\
\text { http://tietokayttoon.fi/documents/10616/3866814/21_Energia- } \\
\text { +ja+ilmastostrategian+vaikutusarviot+Yhteenvetoraportti/4odf } 1 f_{5} f-c 99 c-47 d_{1} \text {-ag29- } \\
\text { a4c825f71547?version=1.0 }\end{array}$ \\
\hline 2017 & Prime Minister's Office & $\begin{array}{l}\text { Hajautetun uusiutuvan energian mahdollisuudet ja rajoitteet. [Opportunities and } \\
\text { limitations of distributed (production of renewable) energy.] } \\
\text { http://vnk.fi/documents/10616/3866814/35_hajautetun-uudiutuvan-energian- } \\
\text { mahdollisuudet-ja-rajoitteet.pdf/331354b7-1bog-4fc9-bo1a-8gffo8b87241?version=1.0 }\end{array}$ \\
\hline 2016 & Prime Minister's Office & $\begin{array}{l}\text { Vuoden } 2011 \text { energiaverouudistuksen arviointia [Evaluation of } 2011 \text { energy tax reform] } \\
\text { http://tietokayttoon.fi/documents/10616/2009122/61_Vuoden+2011+energiaverouudis } \\
\text { tuksen+arviointia/73aagc40-c490-4b83-bbga-eb4d3agf193b?version=1.0 }\end{array}$ \\
\hline 2016 & Prime Minister's Office & $\begin{array}{l}\text { Biotalous ja cleantech Suomessa - strategioiden arviointi ja toimenpidesuositukset. } \\
\text { [Bioeconomy and cleantech in Finland - Assessment of Strategies and development } \\
\text { suggestions.] } \\
\text { http://vnk.fi/documents/10616/2009122/51_Biotalous+ja+cleantech+Suomessa+\%E2\% } \\
80 \% 93+\text { strategioiden+arviointi+ja+toimenpidesuositukset/5b3f622c-d593-4a84-a38o- } \\
\text { ad5508gfb75f?version=1.1 }\end{array}$ \\
\hline 2016 & Prime Minister's Office & $\begin{array}{l}\text { Kohdennetut keinot kierrätyksen kasvuun. [Policy instruments for increasing waste } \\
\text { recycling] } \\
\text { http://tietokayttoon.fi/documents/10616/2009122/53_2016+Kohdennetut+keinot+kierr } \\
\% C_{3} \% A_{4} \text { tyksen+kasvuun.pdf/e883402b-13dc-4d69-8126-953c8occ1b8f?version=1.0 }\end{array}$ \\
\hline 2016 & $\begin{array}{l}\text { Ministry of Employment and the } \\
\text { Economy }\end{array}$ & $\begin{array}{l}\text { Uusiutuvan energian tukijärjestelmien kehittämistyöryhmän loppuraportti. [Final } \\
\text { Report of the Working Group for Developing Support Schemes for Renewable Energy.] } \\
\text { http://julkaisut.valtioneuvosto.fi/bitstream/handle/10024/74933/TEMjul_16_2016.pdf }\end{array}$ \\
\hline 2016 & Prime Minister's Office & $\begin{array}{l}\text { Yhden luukun periaatteen toteuttaminen ympäristöasioissa [The implementation of } \\
\text { the one-stop shop principle in environmental matters] } \\
\text { http://tietokayttoon.fi/documents/10616/2009122/29_Yhden+luukun+periaatteen+tot } \\
\text { euttaminen+ymp\%C3\%A4rist\%C3\%B6asioissa.pdf/a2co1baa-48f9-4719-88b7- } \\
\text { e74ff7837eb7?version=1.0 }\end{array}$ \\
\hline 2015 & $\begin{array}{l}\text { Ministry of Employment and the } \\
\text { Economy }\end{array}$ & $\begin{array}{l}\text { Selvitys energiapolitiikan vaihtoehdoista. [Report on Energy Policy Options.] } \\
\text { http://julkaisut.valtioneuvosto.fi/bitstream/handle/10024/74969/TEMjul_25_2015- } \\
\text { web_01042015.pdf }\end{array}$ \\
\hline 2013 & Ministry of the Environment & $\begin{array}{l}\text { Ympäristön kannalta haitalliset tuet. [Environmentally harmful subsidies]. } \\
\text { http://www.ym.fi/download/noname/\%7BB3E047CC-DD7A-4897-BA56- } \\
5_{513 F B D C}{ }_{50} C_{5} \text { F\%7D/40297 }\end{array}$ \\
\hline 2012 & $\begin{array}{l}\text { Finnish Environment Institute } \\
\text { SYKE }\end{array}$ & $\begin{array}{l}\text { Kiviaineshankkeiden ympäristövaikutusten arviointi. [Environmental impact } \\
\text { assessment of aggregate projects] } \\
\text { https://helda.helsinki.fi/bitstream/handle/10138/38737/SY_27_2012_Kiviaineshankkeid } \\
\text { en_ymparistovaikutusten_arviointi.pdf?sequence=1 }\end{array}$ \\
\hline
\end{tabular}




\title{
Appendix B: Assessment of 32 evaluations
}

\author{
Denmark
}

\author{
Ex-ante evaluations
}

Table B-1: Denmark, No. 1

\begin{tabular}{|c|c|c|}
\hline Title & \multicolumn{2}{|c|}{$\begin{array}{l}\text { Afgifter der forandrer - Forslag til klimavenlige afgiftsomlægninger } \\
\text { [Charges that give change - Proposals for climate-friendly tax changes] }\end{array}$} \\
\hline Date & \multicolumn{2}{|c|}{ June 2016} \\
\hline Source & \multicolumn{2}{|c|}{ http://klimarådet.dk/da/rapporter/afgifter-der-forandrer } \\
\hline Client & \multicolumn{2}{|c|}{$\begin{array}{l}\text { Klimarådet (although targeted at the Parliament's implementation of its climate law) } \\
\text { [Danish Council on Climate Change] }\end{array}$} \\
\hline Evaluator & \multicolumn{2}{|c|}{$\begin{array}{l}\text { Klimarådet } \\
\text { [Danish Council on Climate Change] }\end{array}$} \\
\hline Ex-ante/ex-post evaluation & \multicolumn{2}{|c|}{$\begin{array}{l}\text { Ex-post evaluation (assessing recent policy developments) } \\
\text { Ex-ante evaluation (assessing future challenges and needs for policy developments) }\end{array}$} \\
\hline Type of policy instrument & \multicolumn{2}{|r|}{ Economic: taxes } \\
\hline Use of evaluation guideline & \multicolumn{2}{|c|}{$\begin{array}{l}\text { Has been carried out in accordance with prevailing guidelines available on websites of } \\
\text { Ministry of Finance and Ministry of taxes. }\end{array}$} \\
\hline $\begin{array}{l}\text { Brief description of purpose, } \\
\text { results, and main learnings } \\
\text { from the evaluation }\end{array}$ & \multicolumn{2}{|c|}{$\begin{array}{l}\text { Assessment of inefficiencies in the Danish climate/environmental tax system, and } \\
\text { recommendations for climate-friendly adjustments - with a focus on } \\
\text { recommendations for the transport and central heating sectors. } \\
\text { Expert assessments based on a solid theoretical foundation, but without consistent } \\
\text { quantifications of impacts. }\end{array}$} \\
\hline Quality score & Score & Explanation \\
\hline $\begin{array}{l}\text { 2.1 Definitions and coverage } \\
\text { of impacts }\end{array}$ & $\mathrm{H}$ & Wide coverage of well-defined climate-related environmental impacts \\
\hline $\begin{array}{l}2.3 \text { Use of analytical } \\
\text { methods for measuring } \\
\text { impacts }\end{array}$ & M & $\begin{array}{l}\text { Solid theory-based assessment of deficiencies of current environmental } \\
\text { tax system, and so of potential benefits from removing/reducing } \\
\text { deficiencies - but without consistent quantifications. }\end{array}$ \\
\hline $\begin{array}{l}2.5 \text { Stakeholder } \\
\text { consultation }\end{array}$ & L & $\begin{array}{l}\text { No use of stakeholder views (apart from the Council itself) as evidence } \\
\text { base, and no stakeholder consultation in the process of pursuing } \\
\text { acceptance of policy recommendations. }\end{array}$ \\
\hline 2.6 Independency & $\mathrm{H}$ & Well-known, credible Council experts. \\
\hline Consistency score & Score & Explanation \\
\hline $\begin{array}{l}\text { 3.1 Role of evaluation in } \\
\text { policy cycle }\end{array}$ & $\mathrm{L}$ & $\begin{array}{l}\text { Council's own choice to assess environmental/climate taxes (although } \\
\text { acknowledging that they are on the political agenda). }\end{array}$ \\
\hline $\begin{array}{l}\text { 3.2 Comparability of } \\
\text { economic instruments with } \\
\text { other policy instruments }\end{array}$ & $\mathrm{L}$ & Focus on economic instruments only. \\
\hline
\end{tabular}


Table B-2: Denmark, No. 2

\begin{tabular}{|c|c|c|}
\hline Title & \multicolumn{2}{|c|}{$\begin{array}{l}\text { Samfundsøkonomisk vurdering af behandling af imprægneret træaffald } \\
\text { [Socioeconomic assessment of the treatment of impregnated wood waste] }\end{array}$} \\
\hline Date & \multicolumn{2}{|c|}{ May 2017} \\
\hline Source & \multicolumn{2}{|c|}{ http://www2.mst.dk/Udgiv/publikationer/2017/05/978-87-93529-95-3.pdf } \\
\hline Client & \multicolumn{2}{|c|}{$\begin{array}{l}\text { Miljø- og Fødevareministeriet, Miljøstyrelsen } \\
\text { [Ministry of Environment and Food of Denmark, Danish Environmental Protection } \\
\text { Agency] }\end{array}$} \\
\hline Evaluator & \multicolumn{2}{|c|}{ Deloitte Consulting } \\
\hline Ex-ante/ex-post evaluation & \multicolumn{2}{|c|}{ Ex-ante evaluation } \\
\hline Type of policy instrument & \multicolumn{2}{|c|}{ Administrative: target management, technical requirements, legislation } \\
\hline Use of evaluation guideline & \multicolumn{2}{|c|}{ Miljøministeriet (2010) } \\
\hline $\begin{array}{l}\text { Brief description of purpose, } \\
\text { results, and main learnings } \\
\text { from the evaluation }\end{array}$ & \multicolumn{2}{|c|}{$\begin{array}{l}\text { Socio-economic analysis of different scenarios for the end-disposal of CCA- } \\
\text { impregnated woods. } \\
\text { Competent use of the evaluation guideline, but only limited description of the policy } \\
\text { process and the administrative costs of revising 'Restproduktbekendt-gørelsen' } \\
\text { [residual product order]. }\end{array}$} \\
\hline Quality score & Score & Explanation \\
\hline $\begin{array}{l}\text { 2.1 Definitions and coverage } \\
\text { of impacts }\end{array}$ & $\mathrm{H}$ & $\begin{array}{l}\text { Clear definitions and coverage of costs and benefits in the different } \\
\text { treatment scenarios. }\end{array}$ \\
\hline $\begin{array}{l}2.3 \text { Use of analytical } \\
\text { methods for measuring } \\
\text { impacts }\end{array}$ & $\mathrm{H}$ & $\begin{array}{l}\text { Coverage of both budget and socioeconomic calculations. Use of } \\
\text { sensitivity analysis to address uncertainty of calculations. Use of widely- } \\
\text { accepted/standard unit prices for environmental impacts. }\end{array}$ \\
\hline $\begin{array}{l}2.5 \text { Stakeholder } \\
\text { consultation }\end{array}$ & $\mathrm{L}$ & $\begin{array}{l}\text { Use of stakeholder consultation for gathering data/facts, but little use for } \\
\text { assessing expected behavioural changes within the different - although } \\
\text { fixed - scenarios. } \\
\text { No evidence of assessment/acceptance of stakeholders of the scenarios- } \\
\text { hereunder the recommended scenario. }\end{array}$ \\
\hline 2.6 Independency & $\mathrm{H}$ & $\begin{array}{l}\text { Well-known consultancy firm, and external quality assurance by another } \\
\text { well-known consultancy firm. }\end{array}$ \\
\hline Consistency score & Score & Explanation \\
\hline $\begin{array}{l}\text { 3.1 Role of evaluation in } \\
\text { policy cycle }\end{array}$ & L & Limited description of the policy process. \\
\hline $\begin{array}{l}\text { 3.2 Comparability of } \\
\text { economic instruments with } \\
\text { other policy instruments }\end{array}$ & L & $\begin{array}{l}\text { No coverage of economic instruments - although scenarios may imply } \\
\text { exemptions from energy taxes. }\end{array}$ \\
\hline
\end{tabular}


Table B-3: Denmark, No. 3

\begin{tabular}{|c|c|c|}
\hline Title & \multicolumn{2}{|c|}{$\begin{array}{l}\text { Sanering af punktafgifter } \\
\text { [Remidiation of excise duties] }\end{array}$} \\
\hline Date & \multicolumn{2}{|c|}{ October 2017} \\
\hline Source & \multicolumn{2}{|c|}{ http://www.skm.dk/media/1530964/hovedrapport-sanering-af-punktafgifter.pdf } \\
\hline Client & \multicolumn{2}{|c|}{ Ministry of Taxation } \\
\hline Evaluator & \multicolumn{2}{|c|}{$\begin{array}{l}\text { Inter-ministerial working group with the Ministry of Taxation as chairman and } \\
\text { secretary. }\end{array}$} \\
\hline Ex-ante/ex-post evaluation & \multicolumn{2}{|c|}{ Ex-ante/ex-post } \\
\hline Type of policy instrument & \multicolumn{2}{|c|}{ Tariffs } \\
\hline Use of evaluation guideline & \multicolumn{2}{|c|}{$\begin{array}{l}\text { Has established four criteria the suggested changes to tariffs are evaluated on. The } \\
\text { tariffs' impact on the industry is estimated based on the "AMVAB" method described } \\
\text { in the following guideline Erhvervsministeriet (2012). }\end{array}$} \\
\hline $\begin{array}{l}\text { Brief description of purpose, } \\
\text { results, and main learnings } \\
\text { from the evaluation }\end{array}$ & \multicolumn{2}{|c|}{$\begin{array}{l}\text { A committee has suggested a number of proposals for tariffs that can be abolished or } \\
\text { revised. The Ministry of Taxes has in this report analysed whether there are tax-based } \\
\text { reasons for the suggested initiatives. The report finds that the main part of the } \\
\text { suggestions can be met. }\end{array}$} \\
\hline \multicolumn{3}{|l|}{ Quality score } \\
\hline $\begin{array}{l}\text { 2.1 Definitions and coverage } \\
\text { of impacts }\end{array}$ & M & $\begin{array}{l}\text { Focus mainly on socioeconomic effects and effects for the industry. Only } \\
\text { little coverage of environmental impacts. }\end{array}$ \\
\hline $\begin{array}{l}\text { 2.3 Use of analytical } \\
\text { methods for measuring } \\
\text { impacts }\end{array}$ & M & $\begin{array}{l}\text { Use a clear method to assess socioeconomic effects as well as effects for } \\
\text { the industry. However, limited coverage of environmental impacts. }\end{array}$ \\
\hline $\begin{array}{l}2.5 \text { Stakeholder } \\
\text { consultation }\end{array}$ & M & Stakeholders have been able to suggest tariff changes. \\
\hline 2.6 Independency & M & $\begin{array}{l}\text { The analysis has been conducted by an inter-ministerial working group, } \\
\text { which is not independent. However, an external committee consisting of } \\
\text { business and industry organizations has assisted the working group in } \\
\text { conducting the analysis. }\end{array}$ \\
\hline \multicolumn{3}{|l|}{ Consistency score } \\
\hline $\begin{array}{l}3.1 \text { Role of evaluation in } \\
\text { policy cycle }\end{array}$ & $\mathrm{H}$ & \\
\hline $\begin{array}{l}3.2 \text { Comparability of } \\
\text { economic instruments with } \\
\text { other policy instruments }\end{array}$ & L & $\begin{array}{l}\text { Do not assess whether other economic instrument could be more } \\
\text { effective. }\end{array}$ \\
\hline
\end{tabular}




\section{Ex-post evaluations}

Table B-4: Denmark, No. 4

\begin{tabular}{|c|c|c|}
\hline Title & \multicolumn{2}{|c|}{$\begin{array}{l}\text { Evaluering af vandsektorloven } \\
\text { [Evaluation of the water sector law] }\end{array}$} \\
\hline Date & \multicolumn{2}{|c|}{2013} \\
\hline Source & \multicolumn{2}{|r|}{ http://eng.svana.dk/media/203683/evalueringafvandsektorlovenendeligrapport.pdf } \\
\hline Client & \multicolumn{2}{|c|}{$\begin{array}{l}\text { Although not explicitly stated, it appears that the Ministry of Environment (hereunder } \\
\text { the Nature Agency) led a steering committee that also included the Ministry of } \\
\text { Industry, Business and Financial Affairs (hereunder the Secretariat for Water Supply), } \\
\text { the Ministry of Finance, the Ministry for Economic Affairs and the Interior, and the } \\
\text { Ministry of Taxation. }\end{array}$} \\
\hline Evaluator & \multicolumn{2}{|c|}{ Deloitte Consulting, LETT, and DHI } \\
\hline Ex-ante/ex-post evaluation & \multicolumn{2}{|c|}{ Ex-post evaluation } \\
\hline Type of policy instrument & \multicolumn{2}{|c|}{ Administrative: legislation } \\
\hline Use of evaluation guideline & \multicolumn{2}{|c|}{$\begin{array}{l}\text { No-but using the benchmarking model of the Secretariat for Water Supply for } \\
\text { estimating effectiveness potentials. }\end{array}$} \\
\hline $\begin{array}{l}\text { Brief description of } \\
\text { purpose, results, and main } \\
\text { learnings from the } \\
\text { evaluation }\end{array}$ & \multicolumn{2}{|c|}{$\begin{array}{l}\text { Assessment of the effectiveness of the existing legal provisions in meeting the aims of } \\
\text { the water sector reform: higher effectiveness, lower prices, more transparency, and } \\
\text { clearer distribution of tasks, while fulfilling the requirements of the environment, } \\
\text { health conditions, and security of supply. } \\
\text { Assessing many different aims has limited the focus on environmental impacts and has } \\
\text { so limited its role as an environmental policy instrument evaluation. }\end{array}$} \\
\hline Quality score & Score & Explanation \\
\hline $\begin{array}{l}2.1 \text { Definitions and } \\
\text { coverage of impacts }\end{array}$ & L & $\begin{array}{l}\text { While covering many impacts linked to the many targets of the water sector } \\
\text { law - only little coverage of not well-defined environmental impacts. }\end{array}$ \\
\hline $\begin{array}{l}2.3 \text { Use of analytical } \\
\text { methods for measuring } \\
\text { impacts }\end{array}$ & M & $\begin{array}{l}\text { Use of theory-based assessments and benchmarking model. However, } \\
\text { limited coverage environmental impacts. }\end{array}$ \\
\hline $\begin{array}{l}2.5 \text { Stakeholder } \\
\text { consultation }\end{array}$ & $\mathrm{H}$ & $\begin{array}{l}\text { Comprehensive use of interviews and questionnaire survey for data collection } \\
\text { and for obtaining stakeholder views. }\end{array}$ \\
\hline 2.6 Independency & $\mathrm{H}$ & $\begin{array}{l}\text { Well-known consultancy firms - together covering evaluation and water } \\
\text { sector expertise. }\end{array}$ \\
\hline Consistency score & Score & Explanation \\
\hline $\begin{array}{l}\text { 3.1 Role of evaluation in } \\
\text { policy cycle }\end{array}$ & $\mathrm{H}$ & $\begin{array}{l}\text { Requirement to an evaluation three years after the signatory of parties to the } \\
\text { agreement - enables them consider revisions to the agreement. }\end{array}$ \\
\hline $\begin{array}{l}\text { 3.2 Comparability of } \\
\text { economic instruments with } \\
\text { other policy instruments }\end{array}$ & M & $\begin{array}{l}\text { Comprehensive coverage of economic instruments and other policy } \\
\text { instruments. However, only limited assessment of economic incentives for } \\
\text { environmental improvements. }\end{array}$ \\
\hline
\end{tabular}


Table B-5: Denmark, No. 5

\begin{tabular}{|c|c|c|}
\hline Title & \multicolumn{2}{|c|}{$\begin{array}{l}\text { Midt i en energiomstilling - udfordringer og løsninger for den danske PSO-ordning } \\
\text { [In the midst of an energy conversion - challenges and solutions for the Danish PSO } \\
\text { scheme] }\end{array}$} \\
\hline Date & \multicolumn{2}{|c|}{ April 2016} \\
\hline Source & \multicolumn{2}{|c|}{$\begin{array}{l}\text { http://www.klimaradet.dk/da/analyser/midt-i-en-energiomstilling-udfordringer-og- } \\
\text { loesninger-den-danske-pso-ordning }\end{array}$} \\
\hline Client & \multicolumn{2}{|c|}{$\begin{array}{l}\text { Klimarådet (although targeted at the Parliament's implementation of its climate law) } \\
\text { [Danish Council on Climate Change] }\end{array}$} \\
\hline Evaluator & \multicolumn{2}{|c|}{$\begin{array}{l}\text { Klimarådet } \\
\text { [Danish Council on Climate Change] }\end{array}$} \\
\hline Ex-ante/ex-post evaluation & \multicolumn{2}{|c|}{$\begin{array}{l}\text { Ex-post evaluation (assessing recent policy developments) } \\
\text { Ex-ante evaluation (assessing future challenges and needs for policy developments) }\end{array}$} \\
\hline Type of policy instrument & \multicolumn{2}{|c|}{ Economic: subsidies and taxes } \\
\hline Use of evaluation guideline & \multicolumn{2}{|c|}{ No } \\
\hline $\begin{array}{l}\text { Brief description of purpose, } \\
\text { results, and main learnings } \\
\text { from the evaluation }\end{array}$ & \multicolumn{2}{|c|}{$\begin{array}{l}\text { Assessment of current PSO-subsidy (Public Service Obligation) to renewable energy } \\
\text { financed via PSO-taxes on electricity use. } \\
\text { Expert assessments of causes for recent developments in PSO costs and their } \\
\text { distributional impacts, and assessments of future developments and of alternative } \\
\text { financing options. }\end{array}$} \\
\hline Quality score & Score & Explanation \\
\hline $\begin{array}{l}2.1 \text { Definitions and coverage } \\
\text { of impacts }\end{array}$ & M & $\begin{array}{l}\text { Focus on impacts on electricity prices and use. Hence, no assessment of } \\
\text { climate-related environmental impacts. }\end{array}$ \\
\hline $\begin{array}{l}2.3 \text { Use of analytical } \\
\text { methods for measuring } \\
\text { impacts }\end{array}$ & M & $\begin{array}{l}\text { Solid theory-based assessment of links between electricity prices and } \\
\text { electricity use. }\end{array}$ \\
\hline $\begin{array}{l}2.5 \text { Stakeholder } \\
\text { consultation }\end{array}$ & L & $\begin{array}{l}\text { No use of stakeholder views (apart from the Council itself) as evidence } \\
\text { base, and no stakeholder consultation in the process of pursuing } \\
\text { acceptance of policy recommendations. }\end{array}$ \\
\hline 2.6 Independency & $\mathrm{H}$ & Well-known and credible Council experts. \\
\hline Consistency score & Score & Explanation \\
\hline $\begin{array}{l}\text { 3.1 Role of evaluation in } \\
\text { policy cycle }\end{array}$ & M & $\begin{array}{l}\text { Council's own choice to assess the PSO system, but done at a time } \\
\text { where it was under scrutiny being conflict with EU's state aid rules. }\end{array}$ \\
\hline $\begin{array}{l}3.2 \text { Comparability of } \\
\text { economic instruments with } \\
\text { other policy instruments }\end{array}$ & L & Focus on economic instruments only. \\
\hline
\end{tabular}


Table B-6: Denmark, No. 6

\begin{tabular}{|c|c|c|}
\hline Title & \multicolumn{2}{|c|}{ Evaluering af grønne regnskaber [Evaluation of green accounts } \\
\hline Date & \multicolumn{2}{|c|}{2014} \\
\hline Source & \multicolumn{2}{|c|}{ https://www2.mst.dk/Udgiv/publikationer/2014/06/978-87-93178-65-6.pdf } \\
\hline Client & \multicolumn{2}{|c|}{ Ministry of Environment and Food, The Danish Environmental Agency } \\
\hline Evaluator & \multicolumn{2}{|c|}{ COWI } \\
\hline Ex-ante/ex-post evaluation & \multicolumn{2}{|c|}{ Ex-post } \\
\hline Type of policy instrument & \multicolumn{2}{|c|}{ Green accounts } \\
\hline Use of evaluation guideline & \multicolumn{2}{|c|}{ No } \\
\hline $\begin{array}{l}\text { Brief description of purpose, } \\
\text { results, and main learnings } \\
\text { from the evaluation }\end{array}$ & \multicolumn{2}{|c|}{$\begin{array}{l}\text { The evaluation has had two focus areas. One focus area is to clarify whether green } \\
\text { accounts are current and useful in relation to their two purposes hence provide the } \\
\text { public with environmental information and encourage enterprises to work actively with } \\
\text { environmental aspects of their activities. The second focus area is to investigate the } \\
\text { effects of green accounts, including the effects of removing the duty to prepare } \\
\text { accounts for Annex } 2 \text { enterprises. The report finds that green accounts have had a } \\
\text { positive environmental effect the } 19 \text { gos and 2ooos. Though, the evaluation also shows } \\
\text { that the enterprises are subject to other environmental regulation which overlaps } \\
\text { green accounts and therefor green accounts doesn't add an added value in relation to } \\
\text { the environment. }\end{array}$} \\
\hline Quality score & Score & Explanation \\
\hline $\begin{array}{l}\text { 2.1 Definitions and coverage } \\
\text { of impacts }\end{array}$ & L & There is no clear definition of impacts. \\
\hline $\begin{array}{l}2.3 \text { Use of analytical } \\
\text { methods for measuring } \\
\text { impacts }\end{array}$ & $\mathrm{L}$ & Results are only based on answers from stakeholders \\
\hline $\begin{array}{l}2.5 \text { Stakeholder } \\
\text { consultation }\end{array}$ & $\mathrm{H}$ & Questionnaire and interviews with stakeholders \\
\hline ers2.6 Independency & $\mathrm{H}$ & Well-known consultancy firm. \\
\hline Consistency score & Score & Explanation \\
\hline $\begin{array}{l}\text { 3.1 Role of evaluation in } \\
\text { policy cycle }\end{array}$ & $\mathrm{H}$ & $\begin{array}{l}\text { The ministry of Environment promised the Danish Parliament an } \\
\text { evaluation of the effects of green accounts. }\end{array}$ \\
\hline $\begin{array}{l}3.2 \text { Comparability of } \\
\text { economic instruments with } \\
\text { other policy instruments }\end{array}$ & M & $\begin{array}{l}\text { Compare the effect from green accounts with the effect from other } \\
\text { environmental requirements for the industry }\end{array}$ \\
\hline
\end{tabular}


Table B-7: Denmark, No. 7

\begin{tabular}{|c|c|c|}
\hline Title & \multicolumn{2}{|c|}{$\begin{array}{l}\text { Effektvurdering af kemikalieindsatsen 2014-2017 } \\
\text { [Effect assessment of chemical initiatives 2014-2017] }\end{array}$} \\
\hline Date & \multicolumn{2}{|c|}{ Juni 2017} \\
\hline Source & \multicolumn{2}{|c|}{ http://www2.mst.dk/Udgiv/publikationer/2017/06/978-87-93614-02-4.pdf } \\
\hline Client & \multicolumn{2}{|c|}{$\begin{array}{l}\text { Miljø- og Fødevareministeriet } \\
\text { [Ministry of Environment and Food] }\end{array}$} \\
\hline Evaluator & \multicolumn{2}{|c|}{ COWI } \\
\hline Ex-ante/ex-post evaluation & \multicolumn{2}{|c|}{ Ex-post evaluation - as the initiatives have been implemented } \\
\hline Type of policy instrument & \multicolumn{2}{|c|}{ Economic: grants to administrative, informational, and research initiatives. } \\
\hline Use of evaluation guideline & \multicolumn{2}{|c|}{$\begin{array}{l}\text { Effect chain methodology complies with Miljø- og Fødevareministeriet (2016), while } \\
\text { the socio-economic calculations follow Finansministeriet (2017- or rather the } 1999 \\
\text { version). }\end{array}$} \\
\hline $\begin{array}{l}\text { Brief description of purpose, } \\
\text { results, and main learnings } \\
\text { from the evaluation }\end{array}$ & \multicolumn{2}{|c|}{$\begin{array}{l}\text { The purpose of the effect assessment was to establish a foundation for further } \\
\text { chemical initiatives. } \\
\text { It is, however, unlikely that similar funding of a similar set of initiatives will take place } \\
\text { in the future. Hence, the overall analysis of the links between the initiatives and the } \\
\text { overall benefit/cost ratio assessment may not be that valuable for the planning of } \\
\text { future initiatives. } \\
\text { This said, the analysis of the links between the initiatives contributes to establishing } \\
\text { the intervention logic for the single initiative. Furthermore, the specific analyses of the } \\
\text { initiatives make skilful use of analytical methods. }\end{array}$} \\
\hline Quality score & Score & Explanation \\
\hline $\begin{array}{l}2.1 \text { Definitions and coverage } \\
\text { of impacts }\end{array}$ & $\mathrm{H}$ & $\begin{array}{l}\text { Outputs and effects are clearly defined, and the most important impacts } \\
\text { are covered. }\end{array}$ \\
\hline $\begin{array}{l}2.3 \text { Use of analytical } \\
\text { methods for measuring } \\
\text { impacts }\end{array}$ & $\mathrm{H}$ & $\begin{array}{l}\text { Stringent use of effect chain and socio-economic methods - although } \\
\text { the baseline for the evaluation is not entirely clear. }\end{array}$ \\
\hline $\begin{array}{l}2.5 \text { Stakeholder } \\
\text { consultation }\end{array}$ & M & $\begin{array}{l}\text { Use of stakeholder views as evidence base for assessing behavioural } \\
\text { changes from the initiatives, but not for pursuing acceptance of the } \\
\text { evaluation results. }\end{array}$ \\
\hline 2.6 Independency & $\mathrm{H}$ & $\begin{array}{l}\text { The evaluation team is independent and comprises expertise with } \\
\text { chemicals as well as with effect chains and socio-economic analysis. }\end{array}$ \\
\hline Consistency score & Score & Explanation \\
\hline $\begin{array}{l}3.1 \text { Role of evaluation in } \\
\text { policy cycle }\end{array}$ & $\mathrm{L}$ & $\begin{array}{l}\text { The evaluation was conducted as a as part of the preparation of } \\
\text { negotiations for a new Chemical Action Plan (replacing the } 2014 \text { plan - } \\
\text { 17) } \\
\text { The main challenge for the evaluation of the chemical effort initiative } \\
\text { was the fact that it had to do an an ex-post evaluation before most } \\
\text { impacts had materialized } \\
\text { However, the results may guide another, future ex-post evaluation, and } \\
\text { may inspire similar, future initiatives. }\end{array}$ \\
\hline $\begin{array}{l}\text { 3.2 Comparability of } \\
\text { economic instruments with } \\
\text { other policy instruments }\end{array}$ & M & $\begin{array}{l}\text { The evaluation covers grants (economic instrument) to other types of } \\
\text { policy instruments. However, the baseline for the evaluation is not } \\
\text { entirely clear, e.g. effects of other initiatives - some of which may be } \\
\text { replaced by the chemical initiatives. }\end{array}$ \\
\hline
\end{tabular}


Table B-8: Denmark, No. 8

\begin{tabular}{|c|c|c|}
\hline Title & \multicolumn{2}{|c|}{$\begin{array}{l}\text { Evaluering af Miljøteknologisk Uviklings- og Demonstrationsprogram } \\
\text { [Assessment of Environmental Technology Development and Demonstration } \\
\text { Program] }\end{array}$} \\
\hline Date & \multicolumn{2}{|r|}{2017} \\
\hline Source & \multicolumn{2}{|r|}{$\begin{array}{l}\text { http://ecoinnovation.dk/media/187290/evaluering-2017-rapport-final-31-oktober- } \\
\text { 2017.pdf }\end{array}$} \\
\hline Client & \multicolumn{2}{|r|}{ Bestyrelsen for det Miljøteknologiske Udviklings- og Demonstrationsprogram } \\
\hline Evaluator & \multicolumn{2}{|r|}{ Niras, DTU Miljø and DAMVAD Analytics } \\
\hline Ex-ante/ex-post evaluation & \multicolumn{2}{|c|}{ Ex-post } \\
\hline Type of policy instrument & \multicolumn{2}{|c|}{$\begin{array}{l}\text { Program focusing on supporting and promoting the development, testing and } \\
\text { demonstration of new environmental technologies and solutions within water and } \\
\text { climate adaption, waste and resource efficiency, air, noise, chemicals as well as } \\
\text { sustainable development. }\end{array}$} \\
\hline Use of evaluation guideline & \multicolumn{2}{|r|}{ No } \\
\hline $\begin{array}{l}\text { Brief description of purpose, } \\
\text { results, and main learnings } \\
\text { from the evaluation }\end{array}$ & \multicolumn{2}{|c|}{$\begin{array}{l}\text { The purpose of the study was to evaluate the Miljøteknologiske Udviklings- og } \\
\text { Demonstrationsprogram (MUDP) and its initiatives in the period from 2007-2016. The } \\
\text { program has supported projects focusing on new environmental technologies and } \\
\text { solutions economically. The evaluation shows that the program has had a positive } \\
\text { effect on the participating companies' turnover and employment. However, the } \\
\text { companies undertake a considerable risk, as it takes time before the solutions are } \\
\text { ready for the market. }\end{array}$} \\
\hline Quality score & $\begin{array}{l}\text { Scor } \\
\text { e }\end{array}$ & Explanation \\
\hline $\begin{array}{l}2.1 \text { Definitions and coverage } \\
\text { of impacts }\end{array}$ & M & $\begin{array}{l}\text { Focus both on economic (growth, employment and export) and } \\
\text { environmental effects. }\end{array}$ \\
\hline $\begin{array}{l}\text { 2.3 Use of analytical } \\
\text { methods for measuring } \\
\text { impacts }\end{array}$ & M & $\begin{array}{l}\text { The conclusions are based on administrative information about the projects, } \\
\text { results from a questionnaire and interviews with the participants as well as } \\
\text { data from Statistics Denmark and SCOPUS. }\end{array}$ \\
\hline $\begin{array}{l}2.5 \text { Stakeholder } \\
\text { consultation }\end{array}$ & $\mathrm{H}$ & $\begin{array}{l}\text { Views and opinions from participants in the MUDP program have been } \\
\text { included based on the answers from a questionnaire and interviews. }\end{array}$ \\
\hline 2.6 Independency & $\mathrm{H}$ & Experienced and independent evaluation team. \\
\hline Consistency score & $\begin{array}{l}\text { Scor } \\
\text { e }\end{array}$ & Explanation \\
\hline $\begin{array}{l}\text { 3.1 Role of evaluation in } \\
\text { policy cycle }\end{array}$ & M & . \\
\hline $\begin{array}{l}3.2 \text { Comparability of } \\
\text { economic instruments with } \\
\text { other policy instruments }\end{array}$ & L & Not included. \\
\hline
\end{tabular}




\section{Norway}

\section{Ex-ante evaluations}

Table B-9: Norway, No. 1

\begin{tabular}{|c|c|c|}
\hline Title & \multicolumn{2}{|r|}{ Vurdering av virkemidler for økt utsortering av våtorganisk avfall og plastemballasje } \\
\hline Date & \multicolumn{2}{|c|}{15.01 .2016} \\
\hline Source & \multicolumn{2}{|c|}{ http://www.miljodirektoratet.no/Documents/publikasjoner/M522/M522.pdf } \\
\hline Client & \multicolumn{2}{|c|}{ Norwegian Environment Agency } \\
\hline Evaluator & \multicolumn{2}{|c|}{ Østfoldforskning } \\
\hline Ex-ante/ex-post evaluation & \multicolumn{2}{|c|}{ Ex-ante } \\
\hline Type of policy instrument & \multicolumn{2}{|c|}{ Economic, administrative and legal instruments } \\
\hline Use of evaluation guideline & \multicolumn{2}{|c|}{ Guidelines for instruction on ex-ante studies and guidelines for economic analysis } \\
\hline $\begin{array}{l}\text { Brief description of purpose, } \\
\text { results, and main learnings } \\
\text { from the evaluation }\end{array}$ & \multicolumn{2}{|c|}{$\begin{array}{l}\text { The purpose of this study is to make recommendations to the authorities on which } \\
\text { measures are most effective with a view to enhanced sorting of organic waste and } \\
\text { plastic packaging from households and businesses. The overall objective of increased } \\
\text { sorting is to improve utilisation of wastes and to reduce greenhouse gas emissions. }\end{array}$} \\
\hline Quality score & Score & Explanation \\
\hline $\begin{array}{l}2.1 \text { Definitions and coverage } \\
\text { of impacts }\end{array}$ & $\mathrm{H}$ & Evaluating several instruments and clear on the goals. \\
\hline $\begin{array}{l}2.3 \text { Use of analytical } \\
\text { methods for measuring } \\
\text { impacts }\end{array}$ & M & Several methods are used, but the methods are not highlighted. \\
\hline $\begin{array}{l}2.5 \text { Stakeholder } \\
\text { consultation }\end{array}$ & M & Has been in contact with several business related to the issue \\
\hline 2.6 Independency & $\mathrm{H}$ & Experienced and independent evaluation team. \\
\hline Consistency score & Score & Explanation \\
\hline $\begin{array}{l}\text { 3.1 Role of evaluation in } \\
\text { policy cycle }\end{array}$ & M & $\begin{array}{l}\text { The report is meant as a recommendation for the Ministry of Climate and } \\
\text { Environment. }\end{array}$ \\
\hline $\begin{array}{l}3.2 \text { Comparability of } \\
\text { economic instruments with } \\
\text { other policy instruments }\end{array}$ & $\mathrm{H}$ & Both legal, economic and administrative instruments are considered. \\
\hline
\end{tabular}


Table B-10: Norway, No. 2

\begin{tabular}{|c|c|c|}
\hline Title & \multicolumn{2}{|c|}{ Klimatiltak og utslippsbaner mot 2030; Kunnskapsgrunnlag for lavutslippsutvikling } \\
\hline Date & \multicolumn{2}{|c|}{2015} \\
\hline Source & \multicolumn{2}{|c|}{ http://www.miljodirektoratet.no/Documents/publikasjoner/M386/M386.pdf } \\
\hline Client & \multicolumn{2}{|c|}{ Ministry of Climate and Environment } \\
\hline Evaluator & \multicolumn{2}{|c|}{ Norwegian Environment Agency } \\
\hline Ex-ante/ex-post evaluation & \multicolumn{2}{|c|}{ Ex-ante } \\
\hline Type of policy instrument & \multicolumn{2}{|c|}{ Mapping of possibilities and various action packages } \\
\hline Use of evaluation guideline & \multicolumn{2}{|c|}{ Guidelines for instruction on ex-ante studies and guidelines for economic analysis } \\
\hline $\begin{array}{l}\text { Brief description of purpose, } \\
\text { results, and main learnings } \\
\text { from the evaluation }\end{array}$ & \multicolumn{2}{|c|}{$\begin{array}{l}\text { The report is a response to assignments from the Ministry of Climate and Environment } \\
\text { on the knowledge base for low-emission development. The report provides new } \\
\text { figures for historical emissions and projections based on new GWP values and new } \\
\text { emissions forecasts. The projections are divided into quotas and non-quota sectors. } \\
\text { Furthermore, the report provides a review of possible measures that can be realized by } \\
2030 \text { and the impact of various action packages by quota and non-quota sector. The } \\
\text { report contains } 84 \text { job description. These describe what the measures are, emission } \\
\text { reduction potential and gross cost estimates. As far as possible, additional effects are } \\
\text { also described. Possible energy impacts of the measures are also considered. }\end{array}$} \\
\hline Quality score & Score & Explanation \\
\hline $\begin{array}{l}\text { 2.1 Definitions and coverage } \\
\text { of impacts }\end{array}$ & M & Evaluating several action packages, but no clear aim. \\
\hline $\begin{array}{l}2.3 \text { Use of analytical } \\
\text { methods for measuring } \\
\text { impacts }\end{array}$ & $\mathrm{H}$ & Several methods are used, but the methods are not highlighted. \\
\hline $\begin{array}{l}2.5 \text { Stakeholder } \\
\text { consultation }\end{array}$ & L & No use of stakeholder views. \\
\hline 2.6 Independency & $\mathrm{M}$ & Experienced evaluation team, but financed by the government \\
\hline Consistency score & Score & Explanation \\
\hline $\begin{array}{l}\text { 3.1 Role of evaluation in } \\
\text { policy cycle }\end{array}$ & H & $\begin{array}{l}\text { Mapping on emissions compared to targets, and instrument evaluation to } \\
\text { achieve further goals on emission reduction }\end{array}$ \\
\hline $\begin{array}{l}\text { 3.2 Comparability of } \\
\text { economic instruments with } \\
\text { other policy instruments }\end{array}$ & M & $\begin{array}{l}\text { Several different action packages are considered, whereas economic } \\
\text { instruments are not explicitly evaluated, but are an underlying factor. }\end{array}$ \\
\hline
\end{tabular}


Table B-11: Norway, No. 3

\begin{tabular}{|c|c|c|}
\hline Title & \multicolumn{2}{|c|}{$\begin{array}{l}\text { Faglig grunnlag for videreutvikling av den nasjonale og internasjonale klimapolitikken } \\
\text { Klimatiltak mot } 2020 \text { og plan for videre arbeid }\end{array}$} \\
\hline Date & \multicolumn{2}{|r|}{2014} \\
\hline Source & \multicolumn{2}{|c|}{ http://www.miljodirektoratet.no/Documents/publikasjoner/M133/M133.pdf } \\
\hline Client & \multicolumn{2}{|c|}{ Ministry of Climate and Environment } \\
\hline Evaluator & \multicolumn{2}{|c|}{ Norwegian Environment Agency } \\
\hline Ex-ante/ex-post evaluation & \multicolumn{2}{|c|}{ Ex-ante } \\
\hline Type of policy instrument & \multicolumn{2}{|c|}{ Mapping of possibilities, development and further goals to achieve the climate goals. } \\
\hline Use of evaluation guideline & \multicolumn{2}{|c|}{ Guidelines for instruction on ex-ante studies and guidelines for economic analysis. } \\
\hline $\begin{array}{l}\text { Brief description of purpose, } \\
\text { results, and main learnings } \\
\text { from the evaluation }\end{array}$ & \multicolumn{2}{|c|}{$\begin{array}{l}\text { In "Klimakur" 2020, it was assumed that emissions by } 2020 \text { will reach } 42-44 \text { million } \\
\text { tons of } \mathrm{CO}_{2} \text { equivalents, when forestry measures are included, in order to reach the } \\
\text { Climate Change Objective } 1 \text {. It was further assumed that Norway will receive credited } 3 \\
\text { million tons of } \mathrm{CO}_{2} \text { Equivalents as a result of carbon capture in forests and that } \\
\text { Norwegian emissions must be reduced to between } 45-47 \text { million tons of } \mathrm{CO}_{2} \\
\text { equivalents by } 2020 \text {, when forest measures are not included. Rule- and methodological } \\
\text { changes mean that we currently do not know what Norway will be credited under the } \\
\text { Kyoto agreement in } 2020 \text {. We therefore assume that the ambition level outside of } \\
\text { forests is kept unchanged and that Norwegian emissions must be reduced to between } \\
45-47 \text { million tons of } \mathrm{CO}_{2} \text { equivalents by } 2020 \text {. }\end{array}$} \\
\hline Quality score & Score & Explanation \\
\hline $\begin{array}{l}\text { 2.1 Definitions and coverage } \\
\text { of impacts }\end{array}$ & $\mathrm{H}$ & $\begin{array}{l}\text { Evaluating possibilities for several different sectors, but no clear aim of } \\
\text { one instrument in particular. }\end{array}$ \\
\hline $\begin{array}{l}\text { 2.3 Use of analytical } \\
\text { methods for measuring } \\
\text { impacts }\end{array}$ & $\mathrm{H}$ & Several methods are used, but each method are not specified. \\
\hline $\begin{array}{l}2.5 \text { Stakeholder } \\
\text { consultation }\end{array}$ & L & No use of stakeholder views. \\
\hline 2.6 Independency & M & Experienced evaluation team, but financed by the government \\
\hline Consistency score & Score & Explanation \\
\hline $\begin{array}{l}\text { 3.1 Role of evaluation in } \\
\text { policy cycle }\end{array}$ & M & The report is academic advices to further work \\
\hline $\begin{array}{l}3.2 \text { Comparability of } \\
\text { economic instruments with } \\
\text { other policy instruments }\end{array}$ & $\mathrm{H}$ & $\begin{array}{l}\text { Several different instruments are considered, where different economic } \\
\text { instruments are evaluated among other instruments. }\end{array}$ \\
\hline
\end{tabular}


Table B-12: Norway, No. 4

\begin{tabular}{|c|c|c|}
\hline Title & \multicolumn{2}{|c|}{$\begin{array}{l}\text { NOU (Norway's public investigations) 2015:15 Sett pris på miljøet - Rapport fra } \\
\text { grønn skattekommisjon }\end{array}$} \\
\hline Date & \multicolumn{2}{|c|}{9.12 .2015} \\
\hline Source & \multicolumn{2}{|c|}{$\begin{array}{l}\text { https://www.regjeringen.no/contentassets/38978c0304534ce6bd703c7c4cf32fc } \\
\text { 1/no/pdfs/nou201520150015000dddpdfs.pdf }\end{array}$} \\
\hline Client & \multicolumn{2}{|c|}{ Ministry of Finance } \\
\hline Evaluator & \multicolumn{2}{|c|}{ A committee of experts } \\
\hline Ex-ante/ex-post evaluation & \multicolumn{2}{|c|}{ Ex-ante } \\
\hline Type of policy instrument & \multicolumn{2}{|c|}{ Tax regime } \\
\hline Use of evaluation guideline & \multicolumn{2}{|c|}{ No } \\
\hline $\begin{array}{l}\text { Brief description of purpose, } \\
\text { results, and main learnings from } \\
\text { the evaluation }\end{array}$ & \multicolumn{2}{|c|}{$\begin{array}{l}\text { By Royal Decree August } 15,2014 \text {, a committee was appointed to assess how a } \\
\text { green tax reform can contribute to better resource utilization and to fulfill the } \\
\text { goals of the climate settlement. The report is very general and does not } \\
\text { consider one specific }\end{array}$} \\
\hline Quality score & Score & Explanation \\
\hline $\begin{array}{l}\text { 2.1 Definitions and coverage of } \\
\text { impacts }\end{array}$ & M & $\begin{array}{l}\text { There is no clear definition of impacts, but several impacts are } \\
\text { covered }\end{array}$ \\
\hline $\begin{array}{l}2.3 \text { Use of analytical methods for } \\
\text { measuring impacts }\end{array}$ & M & $\begin{array}{l}\text { The methods used are not obvious but the report refers to several } \\
\text { research articles continuously. }\end{array}$ \\
\hline 2.5 Stakeholder consultation & M & $\begin{array}{l}\text { Stakeholders are not involved directly, but the total impact is } \\
\text { considered }\end{array}$ \\
\hline 2.6 Independency & M & $\begin{array}{l}\text { Experienced evaluation team, stated by the government for this } \\
\text { task only }\end{array}$ \\
\hline Consistency score & Score & Explanation \\
\hline $\begin{array}{l}\text { 3.1 Role of evaluation in policy } \\
\text { cycle }\end{array}$ & M & Advice on further tax regime, to the Ministry of Finance \\
\hline $\begin{array}{l}3.2 \text { Comparability of economic } \\
\text { instruments with other policy } \\
\text { instruments }\end{array}$ & $\mathrm{L}$ & Only economic instruments are considered \\
\hline
\end{tabular}




\section{Ex-post evaluations}

Table B-13: Norway, No. 5

\begin{tabular}{|l|l|l|}
\hline Title & Consequences of low carbon prices in the EU ETS \\
\hline Date & 2014 \\
\hline Source & http://www.miljodirektoratet.no/Documents/publikasjoner/M151/M151.pdf \\
\hline Client & Norwegian Environment Agency \\
\hline Evaluator & Carbon Limits AS in cooperation with Norsk Energi \\
\hline Ex-ante/ex-post evaluation & Ex-post \\
\hline Type of policy instrument & Carbon quota \\
\hline Use of evaluation guideline & No \\
\hline $\begin{array}{l}\text { Brief description of purpose, } \\
\text { results, and main learnings } \\
\text { from the evaluation }\end{array}$ & $\begin{array}{l}\text { The objective of the study was to investigate how the EU ETS price level and the } \\
\text { expectations for future ETS prices might impact investments and operational mode of } \\
\text { those companies who operate in Norway and are subject to the ETS system. } \\
\text { Specifically the potential impact of the current low price level on possible locking in of } \\
\text { long term investments or investments that ought not to have been carried out with } \\
\text { higher price level was analyzed. Use of other means (than ETS) that could supplement } \\
\text { or alternatively be used to achieve the desired result was also part of the scope. }\end{array}$ \\
\hline Quality score & Score & Explanation \\
\hline $\begin{array}{l}2.1 \text { Definitions and coverage } \\
\text { of impacts }\end{array}$ & M & Quota prices and how it affects the carbon emission and capture \\
\hline $\begin{array}{l}\text { 2.3 Use of analytical } \\
\text { methods for measuring } \\
\text { impacts }\end{array}$ & M & To some extend by looking at EU ETS price level \\
\hline $\begin{array}{l}\text { 2.5 Stakeholder } \\
\text { consultation }\end{array}$ & H & Interviews with related businesses \\
\hline 2.6 Independency & H & Experienced and independent evaluation team. \\
\hline Consistency score & Score & Explanation \\
\hline $\begin{array}{l}\text { 3.1 Role of evaluation in } \\
\text { policy cycle }\end{array}$ & L & No particular role \\
\hline $\begin{array}{l}\text { 3.2 Comparability of } \\
\text { economic instruments with } \\
\text { other policy instruments }\end{array}$ & L & No other instruments are evaluated \\
\hline
\end{tabular}


Table B-14: Norway, No. 6

\begin{tabular}{|c|c|c|}
\hline Title & \multicolumn{2}{|r|}{$\begin{array}{l}\text { Miljøvennlige ferjer Realisering av null- og lavutslippsløsninger i anbudsprosesser for } \\
\text { ferjesamband }\end{array}$} \\
\hline Date & \multicolumn{2}{|r|}{08.02 .2016} \\
\hline Source & \multicolumn{2}{|c|}{$\begin{array}{l}\text { http://www.nhosjofart.no/getfile.php/Dokumenter/Publikasjoner/Null- } \\
\text { \%20og\%20lavutslippsferjer\%20i\%20fylkene.pdf }\end{array}$} \\
\hline Client & \multicolumn{2}{|r|}{ Norwegian Environment Agency } \\
\hline Evaluator & \multicolumn{2}{|c|}{ DNV GL AS Maritime } \\
\hline Ex-ante/ex-post evaluation & \multicolumn{2}{|c|}{ Ex-ante/Ex-post } \\
\hline Type of policy instrument & \multicolumn{2}{|c|}{ Economic instruments trough tender processes } \\
\hline Use of evaluation guideline & \multicolumn{2}{|c|}{ N/A } \\
\hline $\begin{array}{l}\text { Brief description of purpose, } \\
\text { results, and main learnings } \\
\text { from the evaluation }\end{array}$ & \multicolumn{2}{|r|}{$\begin{array}{l}\text { To achieve policy-based climate targets, it is necessary to change to zero and low- } \\
\text { emission technology in a number of sectors. This report looks at ferry traffic as one of } \\
\text { the transport sectors where it is now becoming necessary to switch from fossil fuel to } \\
\text { electricity and other zero and low-emission solutions. DNV GL has, on behalf of the } \\
\text { Ministry of the Environment and Environment, carried out a survey of barriers and } \\
\text { solutions in order for such technologies to win on county municipal ferry connections. } \\
\text { The work was initiated on the basis of the government's maritime strategy, and will be } \\
\text { part of the basis for further follow-up of the strategy. Along with the report, The } \\
\text { Norwegian Parliament has also made a decision that provides important guidance in } \\
\text { further work on low and zero emissions in the ferry industry. }\end{array}$} \\
\hline Quality score & $\begin{array}{l}\text { Scor } \\
\text { e }\end{array}$ & Explanation \\
\hline $\begin{array}{l}2.1 \text { Definitions and coverage } \\
\text { of impacts }\end{array}$ & M & $\begin{array}{l}\text { Goal on ferries to be electrified but no clear goal of the emission reduction } \\
\text { due to electrical ferries. }\end{array}$ \\
\hline $\begin{array}{l}2.3 \text { Use of analytical } \\
\text { methods for measuring } \\
\text { impacts }\end{array}$ & L & Little use of measuring impacts. \\
\hline $\begin{array}{l}2.5 \text { Stakeholder } \\
\text { consultation }\end{array}$ & $\mathrm{H}$ & Interviews with related businesses \\
\hline 2.6 Independency & $\mathrm{H}$ & Experienced and independent evaluation team. \\
\hline Consistency score & $\begin{array}{l}\text { Scor } \\
\text { e }\end{array}$ & Explanation \\
\hline $\begin{array}{l}3.1 \text { Role of evaluation in } \\
\text { policy cycle }\end{array}$ & M & Evaluation to implement future tenders \\
\hline $\begin{array}{l}3.2 \text { Comparability of } \\
\text { economic instruments with } \\
\text { other policy instruments }\end{array}$ & M & Economic instruments are evaluated together with technological facilitation \\
\hline
\end{tabular}


Table B-15: Norway, No. 7

\begin{tabular}{|c|c|c|}
\hline Title & \multicolumn{2}{|c|}{ Undersøkelse av myndighetenes arbeid for å sikre god luftkvalitet i byområder } \\
\hline Date & \multicolumn{2}{|c|}{24.11 .2015} \\
\hline Source & \multicolumn{2}{|c|}{ https://www.riksrevisjonen.no/rapporter/Documents/2015-2016/LuftkvalitetBy.pdf } \\
\hline Client & \multicolumn{2}{|c|}{ The Norwegian Parliamentn (Stortinget) } \\
\hline Evaluator & \multicolumn{2}{|c|}{ Riksrevisjonen } \\
\hline Ex-ante/ex-post evaluation & \multicolumn{2}{|c|}{ Ex-post } \\
\hline Type of policy instrument & \multicolumn{2}{|c|}{ General policy } \\
\hline Use of evaluation guideline & \multicolumn{2}{|c|}{ Yes } \\
\hline $\begin{array}{l}\text { Brief description of purpose, } \\
\text { results, and main learnings } \\
\text { from the evaluation }\end{array}$ & \multicolumn{2}{|c|}{$\begin{array}{l}\text { The aim of the survey has been to assess the authorities' efforts to ensure good air } \\
\text { quality. The study highlights the development and status of concentration levels of } \\
\left.\text { particulate matter (PM10) and nitrogen dioxide ( } \mathrm{NO}_{2}\right) \text { in } 14 \text { Norwegian "kommuner" } \\
\text { and urban areas, with a total population of } 1.9 \text { million, which have so high levels of dust } \\
\text { and / or nitrogen dioxide that they are required to monitor pollution levels. }\end{array}$} \\
\hline Quality score & Score & Explanation \\
\hline $\begin{array}{l}\text { 2.1 Definitions and coverage } \\
\text { of impacts }\end{array}$ & $\mathrm{H}$ & Clear aim on goals and impacts \\
\hline $\begin{array}{l}2.3 \text { Use of analytical } \\
\text { methods for measuring } \\
\text { impacts }\end{array}$ & $\mathrm{H}$ & Clear on the impacts measured \\
\hline $\begin{array}{l}2.5 \text { Stakeholder } \\
\text { consultation }\end{array}$ & M & $\begin{array}{l}\text { Riksrevisjonen has been in contact with the authorities during their } \\
\text { work. }\end{array}$ \\
\hline 2.6 Independency & M & Governmental monitor \\
\hline Consistency score & Score & Explanation \\
\hline $\begin{array}{l}\text { 3.1 Role of evaluation in } \\
\text { policy cycle }\end{array}$ & $\mathrm{H}$ & $\begin{array}{l}\text { Evaluating the general policy and giving feedback directly to the } \\
\text { government }\end{array}$ \\
\hline $\begin{array}{l}3.2 \text { Comparability of } \\
\text { economic instruments with } \\
\text { other policy instruments }\end{array}$ & M & No instruments are evaluated in particular, but the general policy. \\
\hline
\end{tabular}


Table B-16: Norway, No. 8

\begin{tabular}{|c|c|c|}
\hline Title & \multicolumn{2}{|r|}{ Byer og miljø. Indikatorer for miljøutviklingen i «Framtidens byer» } \\
\hline Date & \multicolumn{2}{|c|}{ 16th of April 2015} \\
\hline Source & \multicolumn{2}{|c|}{$\begin{array}{l}\text { https://www.ssb.no/natur-og-miljo/artikler-og- } \\
\text { publikasjoner/_attachment/225738?_ts=14d1deb5aa8 }\end{array}$} \\
\hline Client & \multicolumn{2}{|c|}{ Ministry of Local Government and Modernisation } \\
\hline Evaluator & \multicolumn{2}{|c|}{ Statistics Norway (SSB) } \\
\hline Ex-ante/ex-post evaluation & \multicolumn{2}{|c|}{ Ex-post } \\
\hline Type of policy instrument & \multicolumn{2}{|r|}{$\begin{array}{l}\text { No particular instrument is evaluated but decision from The Norwegian Parliament no. } \\
26(2006-2007) \text { on the nation's environmental status and the governmental policy. }\end{array}$} \\
\hline Use of evaluation guideline & \multicolumn{2}{|r|}{ Different parameters are measured, but not according to any particular guideline. } \\
\hline $\begin{array}{l}\text { Brief description of purpose, } \\
\text { results, and main learnings } \\
\text { from the evaluation }\end{array}$ & \multicolumn{2}{|c|}{$\begin{array}{l}\text { This report contains selected indicators and statistics that describe the environmental } \\
\text { status and development in two large urban settlements and } 10 \text { of the most populous } \\
\text { municipalities in Norway. These } 13 \text { areas were included in the programme "Cities of } \\
\text { the Future", As of } 1 \text { January } 2015 \text {, there were just under } 1.9 \text { million inhabitants in the } \\
\text { "Cities of the Future", which corresponds to } 36 \text { per cent of the population of Norway. }\end{array}$} \\
\hline Quality score & Score & Explanation \\
\hline $\begin{array}{l}2.1 \text { Definitions and coverage } \\
\text { of impacts }\end{array}$ & M & $\begin{array}{l}\text { Several impacts are measured, but little or no focus on economic instruments } \\
\text { used to achieve or implements the environmental goals. }\end{array}$ \\
\hline $\begin{array}{l}2.3 \text { Use of analytical } \\
\text { methods for measuring } \\
\text { impacts }\end{array}$ & M & $\begin{array}{l}\text { The use of analytical methods are mostly statistics on different parameters of } \\
\text { interest. No particular guideline on economic measurements are discussed. }\end{array}$ \\
\hline $\begin{array}{l}2.5 \text { Stakeholder } \\
\text { consultation }\end{array}$ & $\mathrm{H}$ & $\begin{array}{l}\text { Cooperation led by the Ministry of Climate and Environment through an } \\
\text { annual top meating with political leadership on national and local level } \\
\text { together private businesses in the } 13 \text { most densely populated areas/cities. }\end{array}$ \\
\hline 2.6 Independency & $\mathrm{H}$ & $\begin{array}{l}\text { Statistics Norway is both a statistical publisher and politically independent } \\
\text { research institute, which also has to protect the confidence of independence } \\
\text { among the population. }\end{array}$ \\
\hline Consistency score & Score & Explanation \\
\hline $\begin{array}{l}\text { 3.1 Role of evaluation in } \\
\text { policy cycle }\end{array}$ & M & $\begin{array}{l}\text { The report doesn't specify the role in the evaluation cycle, but due to the fora } \\
\text { the report is considered, it is natural to believe the results are considered in } \\
\text { further political work. }\end{array}$ \\
\hline $\begin{array}{l}\text { 3.2 Comparability of } \\
\text { economic instruments with } \\
\text { other policy instruments }\end{array}$ & L & $\begin{array}{l}\text { Doesn't give any comparability on different instruments neither economic, } \\
\text { law or administration. }\end{array}$ \\
\hline
\end{tabular}




\section{Sweden}

\section{Ex-ante evaluations}

\section{Table B-17: Sweden, No. 1}

\begin{tabular}{|c|c|c|}
\hline Title & \multicolumn{2}{|c|}{$\begin{array}{l}\text { "Minskad förbrukning av plastbärkassar" } \\
\text { "Reduced consumption of plastic carriers" }\end{array}$} \\
\hline Date & \multicolumn{2}{|c|}{21.03 .2016} \\
\hline Source & \multicolumn{2}{|c|}{$\begin{array}{l}\text { http://www.naturvardsverket.se/upload/miljoarbete-i-samhallet/miljoarbete-i- } \\
\text { sverige/regeringsuppdrag/2016/rapport-plastbarkassar-v16.pdf }\end{array}$} \\
\hline Client & \multicolumn{2}{|c|}{ Ministry of environment and energy } \\
\hline Evaluator & \multicolumn{2}{|c|}{ Swedish Environmental Protection Agency } \\
\hline Ex-ante/ex-post evaluation & \multicolumn{2}{|c|}{ Ex-ante } \\
\hline Type of policy instrument & \multicolumn{2}{|c|}{ Economic, administrative and information } \\
\hline Use of evaluation guideline & \multicolumn{2}{|c|}{ No use of evaluation guideline } \\
\hline $\begin{array}{l}\text { Brief description of purpose, } \\
\text { results, and main learnings } \\
\text { from the evaluation }\end{array}$ & \multicolumn{2}{|c|}{$\begin{array}{l}\text { The purpose of the study was to propose a policy instrument aiming to reduce the } \\
\text { private consumption of plastic carriers to the year of } 2025 \text {. Several different policy } \\
\text { instruments were analyzed, including economic instruments, ban and information. }\end{array}$} \\
\hline Quality score & Score & Explanation \\
\hline $\begin{array}{l}\text { 2.1 Definitions and coverage } \\
\text { of impacts }\end{array}$ & M & $\begin{array}{l}\text { Environmental impacts are analyzed in terms of effects on littering and } \\
\mathrm{CO}_{2} \text { emissions. Implications for retail trade and consumers are covered. } \\
\text { No social impacts are analyzed. }\end{array}$ \\
\hline $\begin{array}{l}\text { 2.3 Use of analytical } \\
\text { methods for measuring } \\
\text { impacts }\end{array}$ & L & $\begin{array}{l}\text { Qualitative assessments of impacts are performed. No use of } \\
\text { quantitative estimates and no use of a model such as cost- benefit } \\
\text { analysis. }\end{array}$ \\
\hline $\begin{array}{l}2.5 \text { Stakeholder } \\
\text { consultation }\end{array}$ & $\mathrm{L}$ & $\begin{array}{l}\text { Dialog performed with retail industry for collection of data, but no } \\
\text { consultation of results. }\end{array}$ \\
\hline 2.6 Independency & M & $\begin{array}{l}\text { Experienced evaluation team, but commissioned and formulated by the } \\
\text { government. }\end{array}$ \\
\hline Consistency score & Score & Explanation \\
\hline \multicolumn{3}{|l|}{$\begin{array}{l}\text { 3.1 Role of evaluation in } \\
\text { policy cycle }\end{array}$} \\
\hline $\begin{array}{l}3.2 \text { Comparability of } \\
\text { economic instruments with } \\
\text { other policy instruments }\end{array}$ & $\mathrm{H}$ & The analysis covers a range of different policy instruments. \\
\hline
\end{tabular}


Table B-18: Sweden, No. 2

\begin{tabular}{|c|c|c|}
\hline Title & \multicolumn{2}{|c|}{$\begin{array}{l}\text { Förslag till utvecklad nationell strategi för energieffektiviserande renovering } \\
\text { "Proposals for developed national strategy for energy-efficient renovation" }\end{array}$} \\
\hline Date & \multicolumn{2}{|c|}{ December 2015} \\
\hline Source & \multicolumn{2}{|c|}{$\begin{array}{l}\text { https://www.google.se/url?sa=t\&rct=j\&q=\&esrc=s\&source=web\&cd=2\&ved=0ahUKEwilmqaH3 } \\
\text { P3YAhWFXCwKHXS1A2MQFggyMAE\&url=https\%3A\%2F\%2Fwww.boverket.se\%2Fglobalassets\% } \\
\text { 2Fpublikationer\%2Fdokument\%2F2015\%2Fforslag-till-utvecklad-nationell-strategi-for- } \\
\text { energieffektiviserande-renovering.pdf\&usg=AOvVaw23vatf2uv8joXINDxCyggf }\end{array}$} \\
\hline Client & \multicolumn{2}{|r|}{ Ministry of environment and energy } \\
\hline Evaluator & \multicolumn{2}{|c|}{ National Board of Housing, Building and Planning and the Swedish Energy Agency } \\
\hline $\begin{array}{l}\text { Ex-ante/ex-post } \\
\text { evaluation }\end{array}$ & \multicolumn{2}{|c|}{ Ex-ante } \\
\hline $\begin{array}{l}\text { Type of policy } \\
\text { instrument }\end{array}$ & \multicolumn{2}{|c|}{ Economic/financial instrument } \\
\hline $\begin{array}{l}\text { Use of evaluation } \\
\text { guideline }\end{array}$ & \multicolumn{2}{|c|}{ No use of evaluation guideline } \\
\hline $\begin{array}{l}\text { Brief description of } \\
\text { purpose, results, } \\
\text { and main learnings } \\
\text { from the evaluation }\end{array}$ & \multicolumn{2}{|c|}{$\begin{array}{l}\text { Two instruments, one based on information and one financial instrument, are evaluated based } \\
\text { on potential effect on energy efficiency and renovation rate for buildings. The study proposes } \\
\text { that existing credit guarantees are extended to include renovation measures aimed at } \\
\text { increasing the rate of renovation. }\end{array}$} \\
\hline Quality score & Score & Explanation \\
\hline $\begin{array}{l}\text { 2.1 Definitions and } \\
\text { coverage of impacts }\end{array}$ & L & $\begin{array}{l}\text { Cost effectiveness i.e. potential of goal fulfillment is evaluated. So are } \\
\text { consequences for stakeholders (the industry). Environmental and social impacts } \\
\text { are not analyzed. }\end{array}$ \\
\hline $\begin{array}{l}2.3 \text { Use of analytical } \\
\text { methods for } \\
\text { measuring impacts }\end{array}$ & M & The analyze addresses cost effectiveness. \\
\hline $\begin{array}{l}2.5 \text { Stakeholder } \\
\text { consultation }\end{array}$ & M & $\begin{array}{l}\text { Stakeholders had the opportunity to comment on main results and comments are } \\
\text { addressed in the written report. }\end{array}$ \\
\hline 2.6 Independency & $\mathrm{M}$ & \\
\hline Consistency score & Score & Explanation \\
\hline \multicolumn{3}{|l|}{$\begin{array}{l}\text { 3.1 Role of } \\
\text { evaluation in policy } \\
\text { cycle }\end{array}$} \\
\hline $\begin{array}{l}3.2 \text { Comparability of } \\
\text { economic } \\
\text { instruments with } \\
\text { other policy } \\
\text { instruments }\end{array}$ & M & $\begin{array}{l}\text { Two different instruments are analyzed, one information based and one financial } \\
\text { instrument. }\end{array}$ \\
\hline
\end{tabular}


Table B-19: Sweden, No. 3

\begin{tabular}{|c|c|c|}
\hline Title & \multicolumn{2}{|c|}{$\begin{array}{l}\text { Kemikalieskatt, Skatt på vissa konsumentvaror som innehåller kemikalier } \\
\text { Chemical tax, Tax on certain consumer goods contai-ning chemicals }\end{array}$} \\
\hline Date & \multicolumn{2}{|c|}{ March 2015} \\
\hline Source & \multicolumn{2}{|r|}{$\begin{array}{l}\text { http://www.google.se/url?sa=t\&rct=j\&q=\&esrc=s\&source=web\&cd=3\&cad=rja\&uact=8\&ved } \\
\text { =0ahUKEwjqj4nS4v3YAhWNYIAKHZM_AJYQFggzMAI\&url=http\%3A\%2F\%2Fwww.regeringen.s } \\
\text { e\%2F49bb0f\%2Fcontentassets\%2F4a79d2c36415435fb2c202dbf54b0bda\%2Fkemikalieskatt- } \\
\text {-skatt-pa-vissa-konsumentvaror-som-innehaller- } \\
\text { kemikalier\&usg=AOvVaw1Uil9NaXGWJ_4Mg-6c5hr1 }\end{array}$} \\
\hline Client & \multicolumn{2}{|c|}{ Ministry of Finance } \\
\hline Evaluator & \multicolumn{2}{|c|}{ Kemikalieskatteutredningen (Public committee) } \\
\hline $\begin{array}{l}\text { Ex-ante/ex-post } \\
\text { evaluation }\end{array}$ & \multicolumn{2}{|c|}{ Ex-ante } \\
\hline $\begin{array}{l}\text { Type of policy } \\
\text { instrument }\end{array}$ & \multicolumn{2}{|c|}{ Economic instruments } \\
\hline $\begin{array}{l}\text { Use of evaluation } \\
\text { guideline }\end{array}$ & \multicolumn{2}{|c|}{ No evaluation guideline used } \\
\hline $\begin{array}{l}\text { Brief description of } \\
\text { purpose, results, and } \\
\text { main learnings from } \\
\text { the evaluation }\end{array}$ & \multicolumn{2}{|c|}{$\begin{array}{l}\text { The main purpose of the study was to analyze the need for economic instruments applied to } \\
\text { chemicals and to propose an instrument design to efficiently and cost effectively reduce the } \\
\text { occurrence or risk for exposure and spread of environmentally hazardous substances from } \\
\text { different product groups. They propose to implement tax on to different product groups, } \\
\text { certain electronics and certain materials including PVC. }\end{array}$} \\
\hline Quality score & Score & Explanation \\
\hline $\begin{array}{l}\text { 2.1 Definitions and } \\
\text { coverage of impacts }\end{array}$ & $\mathrm{H}$ & $\begin{array}{l}\text { Several effects of the policy are analyzed, such as health effects, economic effects } \\
\text { for stakeholders including substitution effects and effects on public finance. A } \\
\text { distributional analysis is performed. Environmental impacts are not covered. }\end{array}$ \\
\hline $\begin{array}{l}2.3 \text { Use of analytical } \\
\text { methods for } \\
\text { measuring impacts }\end{array}$ & $\mathrm{H}$ & Cost benefit analysis performed. \\
\hline $\begin{array}{l}2.5 \text { Stakeholder } \\
\text { consultation }\end{array}$ & M & $\begin{array}{l}\text { The instructions for the analysis include that consultation should be conducted } \\
\text { with relevant authorities as well as relevant stakeholder groups and community } \\
\text { actors. }\end{array}$ \\
\hline 2.6 Independency & M & Conducted by independent expert group. \\
\hline Consistency score & Score & Explanation \\
\hline \multicolumn{3}{|l|}{$\begin{array}{l}\text { 3.1 Role of evaluation } \\
\text { in policy cycle }\end{array}$} \\
\hline $\begin{array}{l}\text { 3.2 Comparability of } \\
\text { economic instruments } \\
\text { with other policy } \\
\text { instruments }\end{array}$ & L & Only economic instruments are analyzed. \\
\hline
\end{tabular}


Table B-20: Sweden, No. 4

\begin{tabular}{|c|c|c|}
\hline Title & \multicolumn{2}{|c|}{$\begin{array}{l}\text { Styrmedel för en hållbar åtgärdstakt av små avloppsanläggningar } \\
\text { Policy instruments for a sustainable pace of action for small sewage plants }\end{array}$} \\
\hline Date & \multicolumn{2}{|c|}{13.09 .2013} \\
\hline Source & \multicolumn{2}{|c|}{$\begin{array}{l}\text { https://www.havochvatten.se/download/18.16a42a771405a5e96072fe6/1379305996556/regu } \\
\text { ppdrag-slutrapport-styrmedel-hallbar-atgardstakt-enskilda-avlopp.pdf }\end{array}$} \\
\hline Client & \multicolumn{2}{|c|}{ Ministry of environment and energy } \\
\hline Evaluator & \multicolumn{2}{|c|}{ Swedish Agency for Marine and Water Management } \\
\hline $\begin{array}{l}\text { Ex-ante/ex-post } \\
\text { evaluation }\end{array}$ & \multicolumn{2}{|c|}{ Ex-ante } \\
\hline $\begin{array}{l}\text { Type of policy } \\
\text { instrument }\end{array}$ & \multicolumn{2}{|c|}{ Economic, administrative and information based instruments } \\
\hline $\begin{array}{l}\text { Use of evaluation } \\
\text { guideline }\end{array}$ & \multicolumn{2}{|l|}{ N/A } \\
\hline $\begin{array}{l}\text { Brief description of } \\
\text { purpose, results, } \\
\text { and main learnings } \\
\text { from the evaluation }\end{array}$ & \multicolumn{2}{|c|}{$\begin{array}{l}\text { The analysis is performed with the main purpose of identifying several policy instruments and } \\
\text { proposing one that decrease emissions from small sewerage plants. Targeted environmental } \\
\text { problem was eutrophication. Several different policy instruments are analyzed, both } \\
\text { economic, administrative and information based instruments. Recommendations are made to } \\
\text { strengthening already existing administrative regulation. }\end{array}$} \\
\hline Quality score & Score & Explanation \\
\hline $\begin{array}{l}\text { 2.1 Definitions and } \\
\text { coverage of impacts }\end{array}$ & $\mathrm{H}$ & $\begin{array}{l}\text { High coverage of impacts including effects on environment, public and private } \\
\text { finance. No social impacts analyzed. Use of scenario analysis for dealing with } \\
\text { uncertainty. }\end{array}$ \\
\hline $\begin{array}{l}2.3 \text { Use of analytical } \\
\text { methods for } \\
\text { measuring impacts }\end{array}$ & $\mathrm{H}$ & Cost benefit analysis performed. \\
\hline $\begin{array}{l}2.5 \text { Stakeholder } \\
\text { consultation }\end{array}$ & $\mathrm{H}$ & $\begin{array}{l}\text { Use of a reference group with representatives from relevant industry, research, } \\
\text { municipalities, state agencies. }\end{array}$ \\
\hline 2.6 Independency & M & $\begin{array}{l}\text { Experienced evaluation team, but commissioned and formulated by the } \\
\text { government. }\end{array}$ \\
\hline Consistency score & Score & Explanation \\
\hline \multicolumn{3}{|l|}{$\begin{array}{l}\text { 3.1 Role of } \\
\text { evaluation in policy } \\
\text { cycle }\end{array}$} \\
\hline $\begin{array}{l}3.2 \text { Comparability of } \\
\text { economic } \\
\text { instruments with } \\
\text { other policy } \\
\text { instruments }\end{array}$ & $\mathrm{H}$ & Several different policy instruments are analyzed. \\
\hline
\end{tabular}




\section{Ex-post evaluations}

\section{Table B-21: Sweden, No. 5}

\begin{tabular}{|c|c|c|}
\hline Title & \multicolumn{2}{|c|}{$\begin{array}{l}\text { Ekonomiska stöd i skogsbruket } \\
\text { Economic subsidies in the forestry }\end{array}$} \\
\hline Date & \multicolumn{2}{|c|}{ November 2015} \\
\hline Source & \multicolumn{2}{|r|}{$\begin{array}{l}\text { https://www.ivl.se/download/18.4b1c947d15125e72dda144d/1449742309518/C1 } \\
\text { 32.pdf }\end{array}$} \\
\hline Client & \multicolumn{2}{|r|}{ Swedish Forests Agency } \\
\hline Evaluator & \multicolumn{2}{|c|}{ IVL Swedish Environmental Institute } \\
\hline Ex-ante/ex-post evaluation & \multicolumn{2}{|c|}{ Ex-post } \\
\hline Type of policy instrument & \multicolumn{2}{|c|}{ Economic instruments } \\
\hline Use of evaluation guideline & \multicolumn{2}{|c|}{ N/A } \\
\hline $\begin{array}{l}\text { Brief description of purpose, } \\
\text { results, and main learnings from } \\
\text { the evaluation }\end{array}$ & \multicolumn{2}{|c|}{$\begin{array}{l}\text { Two subsidy programs implemented in Swedish forestry are evaluated with } \\
\text { respect to cost effectiveness and efficiency. }\end{array}$} \\
\hline Quality score & Score & Explanation \\
\hline $\begin{array}{l}\text { 2.1 Definitions and coverage of } \\
\text { impacts }\end{array}$ & M & $\begin{array}{l}\text { Some effects covered, including goal fulfillment, administrative costs. A } \\
\text { qualitative assessment of impacts on ecosystem services are performed. }\end{array}$ \\
\hline $\begin{array}{l}2.3 \text { Use of analytical methods for } \\
\text { measuring impacts }\end{array}$ & $\mathrm{L}$ & $\begin{array}{l}\text { No systematic or stringent use of established methodology, and } \\
\text { different methodologies are being used. }\end{array}$ \\
\hline 2.5 Stakeholder consultation & $\mathrm{L}$ & Data collection made through stakeholders, but no consultation. \\
\hline 2.6 Independency & M & $\begin{array}{l}\text { Experienced evaluation team, but commissioned and formulated by } \\
\text { client. }\end{array}$ \\
\hline Consistency score & Score & Explanation \\
\hline \multicolumn{3}{|l|}{$\begin{array}{l}\text { 3.1 Role of evaluation in policy } \\
\text { cycle }\end{array}$} \\
\hline $\begin{array}{l}\text { 3.2 Comparability of economic } \\
\text { instruments with other policy } \\
\text { instruments }\end{array}$ & & N/A \\
\hline
\end{tabular}


Table B-22: Sweden, No. 6

\begin{tabular}{|c|c|c|}
\hline Title & \multicolumn{2}{|c|}{$\begin{array}{l}\text { Förgröningen i praktiken - kostnader kontra miljönyttor } \\
\text { Greening in practice - costs and environmental benefits }\end{array}$} \\
\hline Date & \multicolumn{2}{|r|}{27.09 .2016} \\
\hline Source & \multicolumn{2}{|c|}{$\begin{array}{l}\text { http://www2.jordbruksverket.se/download/18.36b894651576a404e02f139/14749 } \\
\text { 66108018/ra16_18.pdf }\end{array}$} \\
\hline Client & \multicolumn{2}{|r|}{ Ministry of Environment and Energy } \\
\hline Evaluator & \multicolumn{2}{|c|}{ Swedish Board of Agriculture } \\
\hline Ex-ante/ex-post evaluation & \multicolumn{2}{|c|}{ Ex-post } \\
\hline Type of policy instrument & \multicolumn{2}{|c|}{ Economic instruments } \\
\hline Use of evaluation guideline & \multicolumn{2}{|c|}{ No use of evaluation guidelines } \\
\hline $\begin{array}{l}\text { Brief description of purpose, } \\
\text { results, and main learnings from } \\
\text { the evaluation }\end{array}$ & \multicolumn{2}{|c|}{$\begin{array}{l}\text { An ex-post evaluation of different economic subsidies aimed at agricultural } \\
\text { businesses is performed. Assessment of effectiveness and achieved environmental } \\
\text { benefits is included as well as costs related to administration and implementation } \\
\text { of actions. Recommendations are made to change or take away the subsidies } \\
\text { based on results showing little environmental benefit. }\end{array}$} \\
\hline Quality score & Score & Explanation \\
\hline $\begin{array}{l}\text { 2.1 Definitions and coverage of } \\
\text { impacts }\end{array}$ & M & $\begin{array}{l}\text { Limited scope of transaction and administrative fees is included, } \\
\text { valuation of environmental benefits is made. No social effects }\end{array}$ \\
\hline $\begin{array}{l}2.3 \text { Use of analytical methods for } \\
\text { measuring impacts }\end{array}$ & M & A limited CBA is performed \\
\hline 2.5 Stakeholder consultation & $\mathrm{L}$ & Use of stakeholder consultation not mentioned in report \\
\hline 2.6 Independency & $\mathrm{M}$ & Experienced evaluation team \\
\hline Consistency score & Score & Explanation \\
\hline \multicolumn{3}{|l|}{$\begin{array}{l}\text { 3.1 Role of evaluation in policy } \\
\text { cycle }\end{array}$} \\
\hline $\begin{array}{l}\text { 3.2 Comparability of economic } \\
\text { instruments with other policy } \\
\text { instruments }\end{array}$ & & N/A \\
\hline
\end{tabular}


Table B-23: Sweden, No. 7

\begin{tabular}{|c|c|c|}
\hline Title & \multicolumn{2}{|c|}{$\begin{array}{l}\text { Styrmedels förutsättningar att styra mot ökad energieffektivisering - en utvärdering av } \\
24 \text { styrmedel } \\
\text { Possibilities for steering towards increased energy efficiency - an evaluation of } 24 \\
\text { policy instruments" }\end{array}$} \\
\hline Date & \multicolumn{2}{|c|}{18.02 .2014} \\
\hline Source & \multicolumn{2}{|c|}{$\begin{array}{l}\text { http://extra.lansstyrelsen.se/energi/SiteCollectionDocuments/Uppföljning/En\%20utvär } \\
\text { dering\%20av\%2024\%20styrmedel_Sweco_\%2020140218.pdf }\end{array}$} \\
\hline Client & \multicolumn{2}{|c|}{ Ministry of Enterprise and Innovation } \\
\hline Evaluator & \multicolumn{2}{|c|}{ Sweco energuide $A B$} \\
\hline Ex-ante/ex-post evaluation & \multicolumn{2}{|c|}{ Ex-post } \\
\hline Type of policy instrument & \multicolumn{2}{|c|}{ Economic, administrative, information and research } \\
\hline Use of evaluation guideline & \multicolumn{2}{|c|}{ No use of evaluation guideline } \\
\hline $\begin{array}{l}\text { Brief description of } \\
\text { purpose, results, and main } \\
\text { learnings from the } \\
\text { evaluation }\end{array}$ & \multicolumn{2}{|c|}{$\begin{array}{l}24 \text { different policy instrument in the energy area is evaluated with respect to } \\
\text { contribution to energy efficiency. Economic, administrative, information based and } \\
\text { research based instruments are included. }\end{array}$} \\
\hline Quality score & Score & Explanation \\
\hline $\begin{array}{l}\text { 2.1 Definitions and } \\
\text { coverage of impacts }\end{array}$ & M & $\begin{array}{l}\text { The large number of instrument analyzed limits naturally the coverage of } \\
\text { impacts. Cost effectiveness and efficiency is analyzed. }\end{array}$ \\
\hline $\begin{array}{l}\text { 2.3 Use of analytical } \\
\text { methods for measuring } \\
\text { impacts }\end{array}$ & $\mathrm{L}$ & $\begin{array}{l}\text { No use of quantification of effects. Different methods are used for } \\
\text { different instruments }\end{array}$ \\
\hline $\begin{array}{l}2.5 \text { Stakeholder } \\
\text { consultation }\end{array}$ & $\mathrm{L}$ & Use of stakeholder consultation not mentioned in report \\
\hline 2.6 Independency & $\mathrm{M}$ & Experienced evaluation team. \\
\hline Consistency score & Score & Explanation \\
\hline \multicolumn{3}{|l|}{$\begin{array}{l}\text { 3.1 Role of evaluation in } \\
\text { policy cycle }\end{array}$} \\
\hline $\begin{array}{l}3.2 \text { Comparability of } \\
\text { economic instruments with } \\
\text { other policy instruments }\end{array}$ & & N/A \\
\hline
\end{tabular}


Table B-24: Sweden, No. 8

\begin{tabular}{|c|c|c|}
\hline Title & \multicolumn{2}{|c|}{$\begin{array}{l}\text { Brännheta skatter! Bör avfallsförbränning och utsläpp av kväveoxider från } \\
\text { energiproduktion beskattas? }\end{array}$} \\
\hline Date & \multicolumn{2}{|c|}{ November 2017} \\
\hline \multicolumn{3}{|l|}{ Source } \\
\hline Client & \multicolumn{2}{|c|}{ Ministry of Finance } \\
\hline Evaluator & \multicolumn{2}{|c|}{ Förbränningsutredningen (Public committee) } \\
\hline Ex-ante/ex-post evaluation & \multicolumn{2}{|c|}{ Ex-ante/ex-post } \\
\hline Type of policy instrument & \multicolumn{2}{|c|}{ Economic instruments } \\
\hline Use of evaluation guideline & \multicolumn{2}{|c|}{ No use of evaluation guideline } \\
\hline $\begin{array}{l}\text { Brief description of purpose, } \\
\text { results, and main learnings } \\
\text { from the evaluation }\end{array}$ & \multicolumn{2}{|c|}{$\begin{array}{l}\text { The analysis have several different purposes. Conditions for implementing a tax on } \\
\text { waste incineration are analyzed. One concluding recommendation drawn from the } \\
\text { analysis is to not implement a tax on waste incineration for the reason that the tax is } \\
\text { not expected to reduce waste since the cost burden is not allocated at the } \\
\text { consumption where waste is generated. Also an ex-post evaluation is performed on an } \\
\text { already implemented economic instrument for reduction of } \mathrm{NO}_{x} \text { emissions from large } \\
\text { combustion plants, the so called } \mathrm{NO}_{x} \text {-fee. Only the ex-post evaluation is evaluated } \\
\text { with scores below. }\end{array}$} \\
\hline Quality score & Score & Explanation \\
\hline $\begin{array}{l}2.1 \text { Definitions and coverage } \\
\text { of impacts }\end{array}$ & $\mathrm{H}$ & $\begin{array}{l}\text { Clear description of evaluated impacts, high coverage including } \\
\text { environmental and health effects and economic costs for relevant industry. }\end{array}$ \\
\hline $\begin{array}{l}\text { 2.3 Use of analytical } \\
\text { methods for measuring } \\
\text { impacts }\end{array}$ & $M$ & \\
\hline $\begin{array}{l}2.5 \text { Stakeholder } \\
\text { consultation }\end{array}$ & M & $\begin{array}{l}\text { Use of reference group with wide representation from different minsitries. } \\
\text { No description of a wider stakeholder consultation in the report. }\end{array}$ \\
\hline 2.6 Independency & $\mathrm{H}$ & Experienced evaluation team. \\
\hline Consistency score & Score & Explanation \\
\hline $\begin{array}{l}\text { 3.1 Role of evaluation in } \\
\text { policy cycle }\end{array}$ & & \\
\hline $\begin{array}{l}3.2 \text { Comparability of } \\
\text { economic instruments with } \\
\text { other policy instruments }\end{array}$ & $\mathrm{H}$ & Comparability with other instrument designs are made. \\
\hline
\end{tabular}




\section{Finland}

\section{Ex ante evaluations}

Table B-25: Finland, No. 1

\begin{tabular}{|c|c|c|}
\hline Title & \multicolumn{2}{|c|}{$\begin{array}{l}\text { Energia- ja ilmastostrategian vaikutusarviot: Yhteenvetoraportti [Impact assessments of } \\
\text { the Energy and Climate strategy: The summary report] }\end{array}$} \\
\hline Date & \multicolumn{2}{|c|}{2.2 .2017} \\
\hline Source & \multicolumn{2}{|c|}{$\begin{array}{l}\text { http://tietokayttoon.fi/documents/10616/3866814/21_Energia- } \\
\text { +ja+ilmastostrategian+vaikutusarviot+Yhteenvetoraportti/40df1f5f-c99c-47d1-a929- } \\
\text { a4c825f71547?version=1.0 }\end{array}$} \\
\hline Client & \multicolumn{2}{|c|}{ Prime Minister's Office } \\
\hline Evaluator & \multicolumn{2}{|c|}{$\begin{array}{l}\text { Teknologian tutkimuskeskus VTT Oy, Suomen ympäristökeskus SYKE, } \\
\text { Luonnovarakeskus LUKE, Terveyden- ja hyvinvoinninlaitos THL, Helsingin yliopisto }\end{array}$} \\
\hline Ex-ante/ex-post evaluation & \multicolumn{2}{|c|}{ Ex-ante evaluation } \\
\hline Type of policy instrument & \multicolumn{2}{|c|}{ Strategy } \\
\hline Use of evaluation guideline & \multicolumn{2}{|c|}{$\begin{array}{l}\text { Not explicitly mentioned, but the applied impact assessment methodology is consistent } \\
\text { with the Ex-ante Evaluation Guidelines of the Ministry of Justice (2007) }\end{array}$} \\
\hline $\begin{array}{l}\text { Brief description of purpose, } \\
\text { results, and main learnings } \\
\text { from the evaluation }\end{array}$ & \multicolumn{2}{|c|}{$\begin{array}{l}\text { This report summarises the outcome of the various impact assessments conducted in } \\
\text { respect of the proposed National Energy and Climate Strategy (issued in November } \\
\text { 2016). } \\
\text { The ex ante evaluations informing the summary report include (but are not limited to) the } \\
\text { following: } \\
\text { Impact Assessment of the EU's } 2030 \text { climate and energy policies for Finland (link); } \\
\text { Report on the evolution and reduction measures of emissions in the relevant sectors by } \\
2030 \text { (link); } \\
\text { Study: "How to Reach } 40 \% \text { Reduction in Carbon Dioxide Emissions from Road Transport } \\
\text { by } 2030 \text { : Propulsion Options and their Impacts on the Economy" (link); } \\
\text { Energy efficiency measures of the transport sector as part of the EU's } 2030 \text { climate and } \\
\text { energy targets: impacts, costs and burden sharing (link); } \\
\text { Impacts of the energy and climate policy in the agricultural sector by } 2030 \text { (link); } \\
\text { Study: "The development of energy efficiency in Finland. Assessments of the past and } \\
\text { the future" (link). } \\
\text { The summary report concludes that the proposed actions and measures overall allow } \\
\text { Finland to reach the targets of the EU Effort Sharing Decision as well as the related } \\
\text { national targets to increase the use of renewable energy, to reduce fossil fuel } \\
\text { consumption, and to increase self-sufficiency of energy consumption. The largest } \\
\text { contribution to reducing emissions would be achieved in the transport sector followed by } \\
\text { the heating of buildings, work machinery, waste management, F-gases and agriculture. } \\
\text { Forest biomass is estimated to be the largest growing renewable energy source between } \\
2015 \text { and } 2030 \text {. }\end{array}$} \\
\hline Quality score & Score & Explanation \\
\hline $\begin{array}{l}\text { 2.1 Definitions and coverage } \\
\text { of impacts }\end{array}$ & $\mathrm{H}$ & $\begin{array}{l}\text { The summary report demonstrates that the impacts of the National Energy } \\
\text { and Climate Strategy have been evaluated in a comprehensive way. The } \\
\text { impacts are assessed both quantitatively and qualitatively. The report also } \\
\text { highlights the limitations and uncertainties related to the evaluation. }\end{array}$ \\
\hline $\begin{array}{l}2.3 \text { Use of analytical methods } \\
\text { for measuring impacts }\end{array}$ & $\mathrm{H}$ & $\begin{array}{l}\text { The evaluation is underpinned by a wide range of analytical methods and tools, } \\
\text { including modelling techniques concerning economic and environmental } \\
\text { aspects. }\end{array}$ \\
\hline $\begin{array}{l}2.5 \text { Stakeholder } \\
\text { consultation }\end{array}$ & M & $\begin{array}{l}\text { Stakeholder consultation has been part of the overall strategy development } \\
\text { process. However, as pointed out in the summary report (p. 110), its role } \\
\text { could be further enhanced by enlarging the consultation's scope to a larger } \\
\text { group of experts and other relevant stakeholders. }\end{array}$ \\
\hline 2.6 Independency & $\mathrm{H}$ & $\begin{array}{l}\text { The evaluation has been conducted by a qualified and experienced team, } \\
\text { representing independent research institutions. }\end{array}$ \\
\hline Consistency score & Score & Explanation \\
\hline $\begin{array}{l}\text { 3.1 Role of evaluation in } \\
\text { policy cycle }\end{array}$ & $\mathrm{H}$ & $\begin{array}{l}\text { Evaluation was an integral part of the policy-making process for the } \\
\text { establishment of the National Energy and Climate Strategy. }\end{array}$ \\
\hline $\begin{array}{l}3.2 \text { Comparability of } \\
\text { economic instruments with } \\
\text { other policy instruments }\end{array}$ & $\mathrm{H}$ & Economic policy instruments are evaluated alongside other policy measures. \\
\hline
\end{tabular}


Table B-26: Finland, No. 2

\begin{tabular}{|c|c|c|}
\hline Title & \multicolumn{2}{|r|}{$\begin{array}{l}\text { Päästökauppadirektiivin uudistamisen vaikutukset Suomen energiasektoriin ja } \\
\text { teollisuuteen [Impacts of the renewal of the EU emissions trading system directive to } \\
\text { the Finnish energy sector and industry] }\end{array}$} \\
\hline Date & \multicolumn{2}{|r|}{30.6 .2017} \\
\hline Source & \multicolumn{2}{|c|}{ http://tietokayttoon.fi/julkaisu?pubid=21101 } \\
\hline Client & \multicolumn{2}{|c|}{ Prime Minister's Office } \\
\hline Evaluators & \multicolumn{2}{|c|}{ Pöyry PLC } \\
\hline Ex-ante/ex-post evaluation & \multicolumn{2}{|c|}{ Ex-ante evaluation } \\
\hline Type of policy instrument & \multicolumn{2}{|c|}{ Legislative act (EU), Economic policy instrument } \\
\hline Use of evaluation guideline & \multicolumn{2}{|c|}{ No express reference to evaluation guidelines } \\
\hline $\begin{array}{l}\text { Brief description of purpose, } \\
\text { results, and main learnings } \\
\text { from the evaluation }\end{array}$ & \multicolumn{2}{|r|}{$\begin{array}{l}\text { The report analyses the proposed changes to the EU emissions trading system } \\
\text { directive from the perspective of Finland. The report was produced during the } \\
\text { legislative process at EU level and aimed to provide additional information to decision- } \\
\text { makers. It compares various scenarios based on the positions of the European } \\
\text { Commission, the European Parliament and the Council. } \\
\text { The purpose of the study was not provide a comprehensive impact assessment, but to } \\
\text { focus specifically on evaluating impacts on the Finnish energy sector and on the } \\
\text { competitiveness of the Finnish export industry. The addressed aspects in particular the } \\
\text { following points: } \\
\text { How do the various options for amending the directive impact the number of free } \\
\text { allowances available to the Finnish industries? } \\
\text { How does the revision of the directive impact the price of electricity and district } \\
\text { heating in Finland, as well as energy production? } \\
\text { How does the allocation of free allowances impact the energy-intensive Finnish export } \\
\text { industries in terms of costs and competitiveness? } \\
\text { Which sectors and technologies could benefit from the funding of the envisaged } \\
\text { Innovation Fund and when would financial support be needed? }\end{array}$} \\
\hline Quality score & Score & Explanation \\
\hline $\begin{array}{l}2.1 \text { Definitions and coverage } \\
\text { of impacts }\end{array}$ & $\mathrm{M} / \mathrm{H}$ & $\begin{array}{l}\text { The study defines specifically which impacts it is evaluating, namely } \\
\text { economic impacts on the Finnish industries. Other impacts are deliberately } \\
\text { scoped out of the study. }\end{array}$ \\
\hline $\begin{array}{l}\text { 2.3 Use of analytical } \\
\text { methods for measuring } \\
\text { impacts }\end{array}$ & $\mathrm{H}$ & $\begin{array}{l}\text { The study makes use of modelling techniques, and provides detailed } \\
\text { economic estimates in connection with the examined options. }\end{array}$ \\
\hline $\begin{array}{l}2.5 \text { Stakeholder } \\
\text { consultation }\end{array}$ & $\mathrm{L}$ & Not performed as part of this study. \\
\hline 2.6 Independency & $\mathrm{H}$ & Independent consultancy firm and experienced evaluation team \\
\hline Consistency score & Score & Explanation \\
\hline $\begin{array}{l}\text { 3.1 Role of evaluation in } \\
\text { policy cycle }\end{array}$ & N/A & $\begin{array}{l}\text { This ex ante evaluation is not part of formal policy processes, but provides } \\
\text { complementary information to decision-makers in the context of an ongoing } \\
\text { EU legislative procedure. }\end{array}$ \\
\hline $\begin{array}{l}\text { 3.2 Comparability of } \\
\text { economic instruments with } \\
\text { other policy instruments }\end{array}$ & $\mathrm{H}$ & $\begin{array}{l}\text { The study is focused on the Emissions Trading System which is an essential } \\
\text { economic instrument of environmental policy. }\end{array}$ \\
\hline
\end{tabular}


Table B-27: Finland, No. 3

\begin{tabular}{|c|c|c|}
\hline Title & \multicolumn{2}{|c|}{$\begin{array}{l}\text { Kohdennetut keinot kierrätyksen kasvuun [Policy instruments for increasing waste } \\
\text { recycling] }\end{array}$} \\
\hline Date & \multicolumn{2}{|c|}{22.11 .2016} \\
\hline Source & \multicolumn{2}{|r|}{$\begin{array}{l}\text { http://tietokayttoon.fi/documents/10616/2009122/53_2016+Kohdennetut+keinot+kier } \\
\text { r\%C3\%A4tyksen+kasvuun.pdf/e883402b-13dc-4d69-8126-953c80cc1b8f?version=1.0 }\end{array}$} \\
\hline Client & \multicolumn{2}{|r|}{ Prime Minister's Office Finland } \\
\hline Evaluators & \multicolumn{2}{|r|}{$\begin{array}{l}\text { SYKE [Finnish Environment Institute], VTT [VTT Technical Research Centre of Finland], } \\
\text { Tilastokeskus [Statistics Finland] }\end{array}$} \\
\hline Ex-ante/ex-post evaluation & \multicolumn{2}{|r|}{ Ex-ante evaluation } \\
\hline Type of policy instrument & \multicolumn{2}{|c|}{ Legislative / Non-legislative } \\
\hline Use of evaluation guideline & \multicolumn{2}{|r|}{$\begin{array}{l}\text { Yes - the report refers to the general ex ante evaluation guidelines issued by the } \\
\text { Ministry of Justice (2007) as well as to the specific ex ante evaluation guidelines issued } \\
\text { by the Ministry of Environment (2013). }\end{array}$} \\
\hline $\begin{array}{l}\text { Brief description of } \\
\text { purpose, results, and main } \\
\text { learnings from the } \\
\text { evaluation }\end{array}$ & \multicolumn{2}{|c|}{$\begin{array}{l}\text { The rationale for the report is to determine how Finland could reach the recycling rate } \\
\text { target set by EU waste directive, i.e. 50\% for municipal solid waste and 70\% for } \\
\text { construction and demolition waste. The report aims to identify and assess the most } \\
\text { relevant and effective policy instruments in this respect. } \\
\text { In terms of municipal solid waste, the evaluated policy options comprise an incineration } \\
\text { tax, tightening the municipal waste management regulations, recycling advice for } \\
\text { households, pay as you throw -systems, the obligation to separate the waste for non- } \\
\text { residential properties and establishing a national advising network. As regards } \\
\text { construction and demolition waste, the assessed policy options include a voluntary } \\
\text { agreement for the construction sector, pre-demolition audits and the use of green } \\
\text { public procurement. } \\
\text { The report is underpinned by the modelling of municipal solid waste volumes - this } \\
\text { provides essential quantitative data for the evaluation. In respect of each analysed } \\
\text { policy option, the report includes the assessment of environmental, economic and } \\
\text { other impacts. Economic impacts are mainly evaluated on a qualitative basis. }\end{array}$} \\
\hline Quality score & Score & Explanation \\
\hline $\begin{array}{l}\text { 2.1 Definitions and } \\
\text { coverage of impacts }\end{array}$ & $\mathrm{H}$ & $\begin{array}{l}\text { The report examines the environmental, economic and other impacts of each } \\
\text { identified policy instrument. }\end{array}$ \\
\hline $\begin{array}{l}\text { 2.3 Use of analytical } \\
\text { methods for measuring } \\
\text { impacts }\end{array}$ & $\mathrm{L} / \mathrm{M}$ & $\begin{array}{l}\text { The report sets out an overall quantitative evaluation of the impact of policy } \\
\text { options for increasing the municipal solid waste recycling rate. However, the } \\
\text { assessment of the specific impacts is performed mainly on a qualitative level. } \\
\text { The report is underpinned by a robust model quantifying waste volumes - } \\
\text { however, a more extensive use of analytical evaluation methods could have } \\
\text { been useful (for example cost-benefit analysis or SWOT analysis). }\end{array}$ \\
\hline $\begin{array}{l}2.5 \text { Stakeholder } \\
\text { consultation }\end{array}$ & $\mathrm{H}$ & $\begin{array}{l}\text { The study makes good use of stakeholder inputs (including specific } \\
\text { workshops gathering experts and industry representatives). }\end{array}$ \\
\hline 2.6 Independency & $\mathrm{H}$ & $\begin{array}{l}\text { The independent team comprises highly qualified experts in the topic } \\
\text { covered by the study. }\end{array}$ \\
\hline Consistency score & Score & Explanation \\
\hline $\begin{array}{l}\text { 3.1 Role of evaluation in } \\
\text { policy cycle }\end{array}$ & $\mathrm{H}$ & $\begin{array}{l}\text { The evaluation supports the national implementation of the EU waste } \\
\text { directive. }\end{array}$ \\
\hline $\begin{array}{l}3.2 \text { Comparability of } \\
\text { economic instruments with } \\
\text { other policy instruments }\end{array}$ & $\mathrm{H}$ & The evaluation covers a range of economic policy instruments. \\
\hline
\end{tabular}


Table B-28: Finland, No. 4

\begin{tabular}{|c|c|c|}
\hline Title & \multicolumn{2}{|c|}{$\begin{array}{l}\text { Yhden luukun periaatteen toteuttaminen ympäristöasioissa [The implementation of } \\
\text { the one-stop shop principle in environmental matters] }\end{array}$} \\
\hline Date & \multicolumn{2}{|c|}{22.6 .2016} \\
\hline Source & \multicolumn{2}{|c|}{$\begin{array}{l}\text { http://tietokayttoon.fi/documents/10616/2009122/29_Yhden+luukun+periaatteen+tot } \\
\text { euttaminen+ymp\%C3\%A4rist\%C3\%B6asioissa.pdf/a2c01baa-48f9-4719-88b7- } \\
\text { e74ff7837eb7?version=1.0 }\end{array}$} \\
\hline Client & \multicolumn{2}{|c|}{ Prime Minister's Office } \\
\hline Evaluators & \multicolumn{2}{|c|}{$\begin{array}{l}\text { University of Eastern Finland (research group on environmental law) } \\
\text { Enlaw Consulting Oy }\end{array}$} \\
\hline Ex-ante/ex-post evaluation & \multicolumn{2}{|c|}{ Ex-ante evaluation } \\
\hline Type of policy instrument & \multicolumn{2}{|c|}{ Legislation } \\
\hline Use of evaluation guideline & \multicolumn{2}{|c|}{$\begin{array}{l}\text { Not explicitly, but the applied impact assessment methodology is broadly consistent } \\
\text { with the Ex-ante Evaluation Guidelines of the Ministry of Justice (2007) }\end{array}$} \\
\hline $\begin{array}{l}\text { Brief description of purpose, } \\
\text { results, and main learnings } \\
\text { from the evaluation }\end{array}$ & \multicolumn{2}{|c|}{$\begin{array}{l}\text { This study examines the feasibility and impacts of combining existing environmental } \\
\text { permit procedures under a one-stop-shop model. The report is backed by } \\
\text { comprehensive background research in a number of relevant topics, and follows } \\
\text { recommendations issued by a high-level expert panel of the Ministry of Environment. } \\
\text { The report provides a comprehensive and detailed description of the status of existing } \\
\text { procedures (incl. regarding the competent authorities). The report presents three case } \\
\text { studies, which analyzes the relevant one-stop-shop models applied in the Netherlands, } \\
\text { Germany and Sweden. The report then compares a set of policy options enabling the } \\
\text { envisaged one-stop-shop approach. On this basis, the preferred policy option is } \\
\text { identified and is further outlined in terms of legal, procedural and technical aspects. An } \\
\text { impact assessment is contained in chapter } 10 \text { of the report. } \\
\text { The proposed one-stop-shop model incorporates three key environmental permit } \\
\text { procedures (related to the Environmental Protection Act, the Land Extraction Act and } \\
\text { the Water Act). }\end{array}$} \\
\hline Quality score & Score & Explanation \\
\hline $\begin{array}{l}\text { 2.1 Definitions and coverage } \\
\text { of impacts }\end{array}$ & M & $\begin{array}{l}\text { The report (chapter 10) covers economic impacts, impacts on public } \\
\text { authorities, environmental impacts, and other societal impacts. However, } \\
\text { the impact assessment only covers the proposed policy option (the } \\
\text { impacts of alternative options are not evaluated). }\end{array}$ \\
\hline $\begin{array}{l}2.3 \text { Use of analytical } \\
\text { methods for measuring } \\
\text { impacts }\end{array}$ & L & $\begin{array}{l}\text { The impacts are assessed only on a qualitative level. There are no } \\
\text { analytical tools used in support of the ex-ante evaluation. }\end{array}$ \\
\hline $\begin{array}{l}2.5 \text { Stakeholder } \\
\text { consultation }\end{array}$ & $\mathrm{M} / \mathrm{H}$ & $\begin{array}{l}\text { The interim report of the study was subject to public consultation (it was } \\
\text { published on the website of the Ministry of Environment). In addition, the } \\
\text { study included a stakeholder workshop and interviews with a wide range } \\
\text { of public and private sector stakeholders. However, stakeholder views are } \\
\text { not explicitly reflected in the impact assessment chapter (chapter 10) so it } \\
\text { is not clear how they have been considered in this respect. }\end{array}$ \\
\hline 2.6 Independency & $\mathrm{H}$ & Highly qualified experts in the field. \\
\hline Consistency score & Score & Explanation \\
\hline $\begin{array}{l}\text { 3.1 Role of evaluation in } \\
\text { policy cycle }\end{array}$ & $\mathrm{H}$ & $\begin{array}{l}\text { The conducted impact assessment was part of preparatory activities } \\
\text { aiming to transform the legislative framework. }\end{array}$ \\
\hline $\begin{array}{l}3.2 \text { Comparability of } \\
\text { economic instruments with } \\
\text { other policy instruments }\end{array}$ & $\mathrm{N} / \mathrm{A}$ & Not applicable in respect of the examined matter. \\
\hline
\end{tabular}




\section{Ex-post evaluations}

Table B-29: Finland, No. 5

\begin{tabular}{|c|c|c|}
\hline Title & \multicolumn{2}{|c|}{$\begin{array}{l}\text { Kansallisen materiaalitehokkuusohjelman arviointi [Evaluation of National Material } \\
\text { Efficiency Programme] }\end{array}$} \\
\hline Date & \multicolumn{2}{|c|}{21.09 .2017} \\
\hline Source & \multicolumn{2}{|c|}{$\begin{array}{l}\text { http://tietokayttoon.fi/documents/10616/3866814/64_Kansallisen+materiaalitehokkuusohjelman+ar } \\
\text { viointi.pdf/9416e1e8-3afa-417c-ba47-468fb55a0707?version=1.0 }\end{array}$} \\
\hline Client & \multicolumn{2}{|c|}{ Prime Minister's Office } \\
\hline Evaluator & \multicolumn{2}{|c|}{$\begin{array}{l}\text { Ramboll Finland Oy } \\
\text { Luonnonvarakeskus Luke [National Resources Institute Finland] }\end{array}$} \\
\hline Ex-ante/ex-post evaluation & \multicolumn{2}{|c|}{ Ex-post evaluation } \\
\hline Type of policy instrument & \multicolumn{2}{|c|}{ Programme } \\
\hline Use of evaluation guideline & \multicolumn{2}{|c|}{ N/A } \\
\hline $\begin{array}{l}\text { Brief description of purpose, } \\
\text { results, and main learnings } \\
\text { from the evaluation }\end{array}$ & \multicolumn{2}{|c|}{$\begin{array}{l}\text { The purpose of the report is to evaluate the implementation of the "national material } \\
\text { efficiency programme" (launched in December 2013), which is composed of eight } \\
\text { measures (and further divided into } 40 \text { different projects). The report also provides } \\
\text { recommendations on how the programme and its components should evolve in the } \\
\text { future. } \\
\text { The study is underpinned by a tailor-made analytical framework which enables a } \\
\text { comprehensive evaluation of the programme in terms of effectiveness, efficiency and } \\
\text { relevance. Several analytical tools are used and the results of the evaluation are } \\
\text { presented both in quantitative and qualitative terms. } \\
\text { The evaluation concludes that whilst only half of the projects within the programme } \\
\text { are focused on material efficiency, these projects have overall been effective in } \\
\text { achieving the set objectives. The report recommends an update of the national } \\
\text { material efficiency programme and a stronger focus on projects which directly } \\
\text { promote material efficiency. }\end{array}$} \\
\hline Quality score & Score & Explanation \\
\hline $\begin{array}{l}\text { 2.1 Definitions and coverage } \\
\text { of impacts }\end{array}$ & $\mathrm{H}$ & $\begin{array}{l}\text { The scope of the evaluation (in terms of assessed impacts) is well defined } \\
\text { and the coverage of impacts is in line with the objectives of the study. The } \\
\text { evaluation of impacts is supported by a set of evaluation questions. Both } \\
\text { direct and indirect impacts are considered. }\end{array}$ \\
\hline $\begin{array}{l}2.3 \text { Use of analytical } \\
\text { methods for measuring } \\
\text { impacts }\end{array}$ & $\mathrm{H}$ & $\begin{array}{l}\text { The evaluation is conducted on the basis of a robust analytical framework, } \\
\text { including appropriate qualitative and quantitative methods/tools for } \\
\text { reviewing and assessing the impacts of the examined measures. }\end{array}$ \\
\hline $\begin{array}{l}2.5 \text { Stakeholder } \\
\text { consultation }\end{array}$ & M & $\begin{array}{l}\text { The study included a stakeholder workshop which gathered relevant } \\
\text { public and private sector actors. However, the study could have included } \\
\text { even more extensive stakeholder consultation and the stakeholder views } \\
\text { could have been highlighted in a more detailed way as part of the report. }\end{array}$ \\
\hline 2.6 Independency & $\mathrm{H}$ & Qualified study team composed of consulting firm and research institute. \\
\hline Consistency score & Score & Explanation \\
\hline $\begin{array}{l}\text { 3.1 Role of evaluation in } \\
\text { policy cycle }\end{array}$ & $\mathrm{H}$ & $\begin{array}{l}\text { The evaluation was conducted in the context of the Government's action } \\
\text { to reform the national material efficiency programme. }\end{array}$ \\
\hline $\begin{array}{l}3.2 \text { Comparability of } \\
\text { economic instruments with } \\
\text { other policy instruments }\end{array}$ & N/A & \\
\hline
\end{tabular}


Table B-30: Finland, No. 6

\begin{tabular}{|c|c|c|}
\hline Title & \multicolumn{2}{|c|}{$\begin{array}{l}\text { Biotalous ja cleantech Suomessa - strategioiden arviointi ja toimenpidesuositukset } \\
\text { [Bioeconomy and cleantech in Finland - Assessment of Strategies and development } \\
\text { suggestions] }\end{array}$} \\
\hline Date & \multicolumn{2}{|c|}{12.12 .2016} \\
\hline Source & \multicolumn{2}{|c|}{$\begin{array}{l}\text { http://tietokayttoon.fi/documents/10616/2009122/51_Biotalous+ja+cleantech+Suome } \\
\text { ssa+\%E2\%80\%93+strategioiden+arviointi+ja+toimenpidesuositukset/5b3f622c-d593- } \\
\text { 4a84-a380-ad55089fb75f?version=1.1 }\end{array}$} \\
\hline Client & \multicolumn{2}{|c|}{ Prime Minister's Office } \\
\hline Evaluators & \multicolumn{2}{|c|}{$\begin{array}{l}\text { SYKE [Finnish Environment Institute] } \\
\text { VTT [VTT Technical Research Centre of Finland] } \\
\text { Gaia Consulting Oy }\end{array}$} \\
\hline Ex-ante/ex-post evaluation & \multicolumn{2}{|c|}{ Ex-post evaluation } \\
\hline Type of policy instrument & \multicolumn{2}{|c|}{ Strategies (range of policy measures) } \\
\hline Use of evaluation guideline & \multicolumn{2}{|c|}{ N/A } \\
\hline $\begin{array}{l}\text { Brief description of purpose, } \\
\text { results, and main learnings } \\
\text { from the evaluation }\end{array}$ & \multicolumn{2}{|c|}{$\begin{array}{l}\text { The report provides an assessment of the Finnish Bioeconomy Strategy and of the } \\
\text { Government Strategy to promote the cleantech sector in Finland (both published May } \\
\text { in 2014). The specific objectives of the study were to identify the level of development } \\
\text { achieved so far with the measures laid out in the strategies, examine whether these } \\
\text { measures are appropriately directed in response to the needs of the constantly } \\
\text { changing bioeconomy and cleantech market, and to put forward recommendations for } \\
\text { the further development of policy measures. The report also includes case studies } \\
\text { looking into six focus areas of the bioeconomy and cleantech sector and reviewing } \\
\text { examples of Finnish companies/products in these focus areas. } \\
\text { The report concludes that the evaluated strategies overall deliver good results. } \\
\text { However, the report also advocated renewed strategy processes as well as actions to } \\
\text { ensure a more effective monitoring and evaluation of its implementation. This entails } \\
\text { in particular the collection of relevant numerical data to enable the measurement of } \\
\text { the progress made against the set strategic objectives. }\end{array}$} \\
\hline Quality score & Score & Explanation \\
\hline $\begin{array}{l}2.1 \text { Definitions and coverage } \\
\text { of impacts }\end{array}$ & L & $\begin{array}{l}\text { The report reviews and examines the impacts of the strategy mostly on a } \\
\text { general, high-level basis. Evaluation results are presented within five } \\
\text { thematic areas: (1) internationalisation/international impact; (2) } \\
\text { educational aspects and creation of conditions for demonstration projects; } \\
\text { (3) framework supporting competitiveness and sustainability; and (4) new } \\
\text { business opportunities and investments. } \\
\text { The analysed impacts are not scoped or categorised; the focus is however } \\
\text { on economic impacts. The authors point out, as a limitation to the } \\
\text { evaluation, the short timeframe between the roll-out of the strategies } \\
\text { (published in May 2014) and the time of production of the evaluation } \\
\text { (March 2016-December 2016). }\end{array}$ \\
\hline $\begin{array}{l}2.3 \text { Use of analytical } \\
\text { methods for measuring } \\
\text { impacts }\end{array}$ & M & $\begin{array}{l}\text { The report is underpinned by econometric and statistical analysis and } \\
\text { supported by case studies. The report recommendations are also backed } \\
\text { by the modelling of future forest biomass resource availability, considering } \\
\text { different scenarios. } \\
\text { The report examines the results of the strategies and provides indications } \\
\text { on their impacts (especially based on expert views and stakeholder } \\
\text { feedback), but these impacts are not investigated/assessed in detail. The } \\
\text { impacts could have been evaluated in a more structured and thorough } \\
\text { manner through the use of analytical methods/tools. }\end{array}$ \\
\hline $\begin{array}{l}2.5 \text { Stakeholder } \\
\text { consultation }\end{array}$ & $\mathrm{H}$ & $\begin{array}{l}\text { The report makes extensive use of stakeholder inputs and views. } \\
\text { Numerous interviews and a workshop were conducted in connection with } \\
\text { the study. }\end{array}$ \\
\hline 2.6 Independency & $\mathrm{H}$ & $\begin{array}{l}\text { The team of evaluators comprises comprehensive expertise in the covered } \\
\text { fields. }\end{array}$ \\
\hline Consistency score & Score & Explanation \\
\hline $\begin{array}{l}\text { 3.1 Role of evaluation in } \\
\text { policy cycle }\end{array}$ & $\mathrm{M}$ & $\begin{array}{l}\text { It is not clear how the evaluation results will be followed up or utilised in } \\
\text { the policy-making process. }\end{array}$ \\
\hline $\begin{array}{l}3.2 \text { Comparability of } \\
\text { economic instruments with } \\
\text { other policy instruments }\end{array}$ & $\mathrm{H}$ & $\begin{array}{l}\text { Economic instruments are an integral part of the evaluated policy } \\
\text { measures. }\end{array}$ \\
\hline
\end{tabular}


Table B-31: Finland, No. 7

\begin{tabular}{|c|c|c|}
\hline Title & \multicolumn{2}{|c|}{ Vuoden 2011 energiaverouudistuksen arviointia [Evaluation of 2011 energy tax reform] } \\
\hline Date & \multicolumn{2}{|c|}{19.12 .2016} \\
\hline Source & \multicolumn{2}{|c|}{$\begin{array}{l}\text { http://tietokayttoon.fi/documents/10616/2009122/61_Vuoden+2011+energiaverouudi } \\
\text { stuksen+arviointia/73aa9c40-c490-4b83-bb9a-eb4d3a9f193b?version=1.0 }\end{array}$} \\
\hline Client & \multicolumn{2}{|c|}{ Prime Minister's Office } \\
\hline Evaluator & \multicolumn{2}{|c|}{ Valtion Taloudellinen Tutkimuskeskus VATT [VATT Institute for Economic Research] } \\
\hline Ex-ante/ex-post evaluation & \multicolumn{2}{|c|}{ Ex-post evaluation } \\
\hline Type of policy instrument & \multicolumn{2}{|c|}{ Legislation (economic policy instruments) } \\
\hline Use of evaluation guideline & \multicolumn{2}{|c|}{ Not applicable } \\
\hline $\begin{array}{l}\text { Brief description of purpose, } \\
\text { results, and main learnings } \\
\text { from the evaluation }\end{array}$ & \multicolumn{2}{|c|}{$\begin{array}{l}\text { The report examines the results of the energy tax reform implemented in } 2011 \text { and } \\
2012, \text { which comprised the following two measures: } \\
\text { Increase of the taxation of fuels and revision of the energy tax regime based on } \mathrm{CO}_{2} \\
\text { emissions; } \\
\text { Increase of the tax refunds granted to the energy-intensive industry, and extension of } \\
\text { the tax refund scheme to a larger number of beneficiaries. } \\
\text { The study aims to evaluate two specific elements: } \\
\text { 1) Have the energy tax refund system and its revision in } 2012 \text { achieved the set policy } \\
\text { objectives? } \\
\text { 2) What was the impact of the changes in terms of transport fuel taxation? } \\
\text { The evaluation is backed by a review of relevant research literature as well as thorough } \\
\text { statistical analysis. } \\
\text { The study concludes firstly that the energy tax refund system has not achieved the set } \\
\text { policy objectives in terms of enhancing the competitiveness of export industries and } \\
\text { may have led to distortions in terms of competition both between and within sectors. } \\
\text { Secondly, as regards the increased taxation of transport fuels (in particular of diesel), } \\
\text { the study estimates that approximately } 70 \% \text { of the diesel tax increase was passed on to } \\
\text { consumer prices. The demand for diesel was deemed to be rather inelastic to the price } \\
\text { and the analysed data also indicate that the tax increase was anticipated by fuel } \\
\text { retailers and transferred to customer prices already several months before the change } \\
\text { entered into force. }\end{array}$} \\
\hline Quality score & Score & Explanation \\
\hline $\begin{array}{l}\text { 2.1 Definitions and coverage } \\
\text { of impacts }\end{array}$ & M & $\begin{array}{l}\text { The study is focused on the evaluation of the economic impacts of the } \\
\text { tax reform. These impacts are thoroughly investigated and quantified. } \\
\text { Environmental impacts are not directly examined as part of the study } \\
\text { but are covered indirectly - it would have been useful to include a } \\
\text { specific focus on environmental impacts as part of the study, in order to } \\
\text { better evaluate the overall effectiveness of the tax reform. }\end{array}$ \\
\hline $\begin{array}{l}\text { 2.3 Use of analytical } \\
\text { methods for measuring } \\
\text { impacts }\end{array}$ & $\mathrm{H}$ & $\begin{array}{l}\text { The study makes use of statistical/numerical analysis and related specific } \\
\text { methods such as panel data regression. In addition, the study has } \\
\text { conducted simulations in order to compensate for the lack of data on } \\
\text { certain key aspects. }\end{array}$ \\
\hline $\begin{array}{l}2.5 \text { Stakeholder } \\
\text { consultation }\end{array}$ & L & Stakeholders have not been consulted in the context of the study. \\
\hline 2.6 Independency & $\mathrm{H}$ & Well-known research institute; qualified study team. \\
\hline Consistency score & Score & Explanation \\
\hline $\begin{array}{l}\text { 3.1 Role of evaluation in } \\
\text { policy cycle }\end{array}$ & M & $\begin{array}{l}\text { This evaluation was commissioned in order to support future policy } \\
\text { developments, but there is no clarity on whether and how the evaluation } \\
\text { will be taken into account in the policy-making process. }\end{array}$ \\
\hline $\begin{array}{l}3.2 \text { Comparability of } \\
\text { economic instruments with } \\
\text { other policy instruments }\end{array}$ & $\mathrm{H}$ & The examined policy measures are economic policy instruments. \\
\hline
\end{tabular}


Table B-32: Finland, No. 8

\begin{tabular}{|c|c|c|}
\hline Title & \multicolumn{2}{|c|}{$\begin{array}{l}\text { Väliarvio Suomen luonnon monimuotoisuuden suojelun ja kestävän käytön } \\
\text { strategiasta ja toimintaohjelmasta vuonna } 2016 \text { [A mid-term review of the Finnish } \\
\text { strategy and action plan for the conservation and sustainable use of biodiversity in } \\
2016 \text { ] }\end{array}$} \\
\hline Date & \multicolumn{2}{|c|}{ May 2017} \\
\hline \multicolumn{3}{|l|}{ Source } \\
\hline Client & \multicolumn{2}{|c|}{ Ministry of the Environment } \\
\hline Evaluator & \multicolumn{2}{|c|}{ Ministry of the Environment } \\
\hline Ex-ante/ex-post evaluation & \multicolumn{2}{|c|}{ Ex-post evaluation } \\
\hline Type of policy instrument & \multicolumn{2}{|c|}{ Strategy (various policy measures) } \\
\hline Use of evaluation guideline & \multicolumn{2}{|c|}{ No } \\
\hline $\begin{array}{l}\text { Brief description of purpose, } \\
\text { results, and main learnings } \\
\text { from the evaluation }\end{array}$ & \multicolumn{2}{|c|}{$\begin{array}{l}\text { The report provides a mid-term review of the Strategy for the Conservation and } \\
\text { Sustainable Use of Biodiversity in Finland for the years } 2012-2020 \text {, adopted by the } \\
\text { Finnish Government in December } 2012 \text {. The strategy (and the associated roadmap) } \\
\text { includes } 105 \text { implementation measures. In connection with the strategy adoption, the } \\
\text { Government established a process for monitoring and assessing its implementation. } \\
\text { The report examines the status and prospects of biodiversity in Finland, and takes } \\
\text { stock of the progress made in the implementation of the strategy actions. The report } \\
\text { identifies the completed, ongoing and pending measures. The environmental impacts } \\
\text { of the strategy are analysed in the key domains of the strategy. } \\
\text { The report concludes that the implementation of the strategy is mainly progressing } \\
\text { well. Some measures are observed to have already had a positive impact, but there are } \\
\text { also continuing negative trends in terms of habitats and species. Accordingly, the } \\
\text { report underscores that additional measures would be needed in order to halt the } \\
\text { decline of biodiversity. }\end{array}$} \\
\hline Quality score & Score & Explanation \\
\hline $\begin{array}{l}\text { 2.1 Definitions and coverage } \\
\text { of impacts }\end{array}$ & M & $\begin{array}{l}\text { The report aims to provide a mid-term review of the strategy, and as such } \\
\text { its purpose is not to lay out a full-fledged evaluation of impacts. However, } \\
\text { it would have been useful, as part of the report, to include at least a } \\
\text { section summarising the observed environmental, economic and societal } \\
\text { impacts of the strategy measures. }\end{array}$ \\
\hline $\begin{array}{l}\text { 2.3 Use of analytical } \\
\text { methods for measuring } \\
\text { impacts }\end{array}$ & L & No use of analytical tools for measuring impacts. \\
\hline $\begin{array}{l}2.5 \text { Stakeholder } \\
\text { consultation }\end{array}$ & M & $\begin{array}{l}\text { This mid-term review was developed under the auspices of a steering } \\
\text { group gathering representatives from } 10 \text { ministries, several government } \\
\text { agencies, research institutions, private sector entities, NGOs and other } \\
\text { stakeholder groups. } \\
\text { However, it is not clear how stakeholder views have been taken into } \\
\text { account in the report conclusions and recommendations. A specific } \\
\text { stakeholder consultation process in the context of the mid-term review } \\
\text { could have been helpful to substantiate the report findings. }\end{array}$ \\
\hline 2.6 Independency & $\mathrm{H}$ & $\begin{array}{l}\text { The authors are civil servants with a high level of knowledge in the covered } \\
\text { field. }\end{array}$ \\
\hline Consistency score & Score & Explanation \\
\hline $\begin{array}{l}\text { 3.1 Role of evaluation in } \\
\text { policy cycle }\end{array}$ & $\mathrm{H}$ & $\begin{array}{l}\text { This mid-term review was required by the Government in order to take } \\
\text { stock of the progress made in the strategy implementation. }\end{array}$ \\
\hline $\begin{array}{l}\text { 3.2 Comparability of } \\
\text { economic instruments with } \\
\text { other policy instruments }\end{array}$ & $\mathrm{N} / \mathrm{A}$ & $\begin{array}{l}\text { Not applicable, as the examined measures do not comprise economic } \\
\text { policy instruments. }\end{array}$ \\
\hline
\end{tabular}




\section{Appendix C: Stakeholders consulted}

\section{Denmark}

- Ministry of Environment and Food of Denmark

- Danish Ministry of Energy, Utilities and Climate

- Brian H. Jacobsen from Department of Food and Resource Economics, Copenhagen University

\section{Norway}

- Ministry of Climate and Environment in Norway

- Norwegian Environment Agency

- Norwegian Government Agency for Financial Management

\section{Sweden}

- Ministry of Finance

- Swedish Environmental Protection agency

- Prof. Patrik Söderholm from Department of Business Administration, Technology and Social Sciences, Luleå University of Technology

\section{Finland}

- Ministry of Environment

- Ministry of Finance 


\section{Appendix D: Literature}

Direktoratet for økonomistyring (DFØ) (2011), "Strategisk og systematisk bruk av evaluering i styringen" https://dfo.no/filer/Fagomr\%(3\% $3 \mathrm{~A}_{5}$ der/Evaluering/Strategisk-og-systematiskbruk-av-evaluering-i-styringen.pdf

Direktoratet for økonomistyring (DFØ) (2014), "Veileder i samfunnsøkonomiske analyser",https://dfo.no/filer/Fagomr\%(3\%A5der/Utredninger/Veileder-isamfunns\% $3 \%$ B8konomiske-analyser.pdf

Direktoratet for økonomistyring (DFØ) (2016), "Veileder til utredningsinstruksen" https://dfo.no/filer/Fagomr\% $3 \mathrm{C}_{3} \% \mathrm{~A}_{5}$ der/Utredninger/Veileder-til-utredningsinstruksen.pdf

EEA (2016), "Environment and climate policy evaluation", http://www.eea.europa.eu/publications/environment-and-climate-policy-evaluation

Energimyndigheten (2015), Metoder för utvärdering av styrmedel - En metautvärdering grundad på litteratur och två fall

Energistyrelsen (2007), "Vejledning i samfundsøkonomiske analyser på energiområdet", https://ens.dk/sites/ens.dk/files/Analyser/vejledning_2005-rev2007.pdf

Erhvervsministeriet (2012), "Manual til Aktivitetsbaseret Måling af Virksomhedernes Administrative Byrder" (AMVAB)", https://erhvervsstyrelsen.dk/sites/default/files/media/amvab-manual.pdf

Erhvervsministeriet (2015), "Vejledning om Erhvervsøkonomiske konsekvensvurderinger", https://erhvervsstyrelsen.dk/sites/default/files/media/vejledning_om_erhvervsoekonomiske_k onsekvensvurderinger.pdf

European Commission (2017), "Better Regulation Guidelines", Commission Staff Working Document, SWD (2017) 350. https://ec.europa.eu/info/sites/info/files/better-regulationguidelines.pdf

Finansministeriet, Indenrigs- og Sundhedsministeriet, Ligestillingsafdelingen, Miljøministeriet, Skatteministeriet, Socialministeriet, og Økonomi- og Erhvervsministeriet (2005), "Vejledning om konsekvensanalyser" [Ministry of Finance et.al., "Guidance on impact assessments"]. https://erhvervsstyrelsen.dk/sites/default/files/vejledning-om-konsekvensanalyser.pdf

Finansministeriet (2017), "Vejledning i samfundsøkonomiske konsekvensvurderinger" [Ministry of Finance, "Guideline for socioeconomic assessments"].

https://www.fm.dk/publikationer/2017/vejledning-i-samfundsoekonomiske-

konsekvensvurderinger

Klimarådet (2016): "Afgifter der forandrer - Forslag til klimavenlige afgiftsomlægninger", http://klimarådet.dk/da/rapporter/afgifter-der-forandrer

Konjunkturinstitutet (2011): "Making Climate Policy efficient. Implementing a model for Environmental Policy Efficiency, Environmental economics, Working Paper no 125"

MH Treasury (2011), "The Magenta Book - Guidance for evaluation", https://www.gov.uk/government/uploads/system/uploads/attachment_data/file/220542/mag enta_book_combined.pdf

Miljøministeriet (2010), "Samfundsøkonomisk vurdering af miljøprojekter" [Ministry of Environment, "Socioeconomic assessment of environment projects"].

http://www2.mst.dk/udgiv/publikationer/2010/978-87-92548-71-

9/pdf/Endelig\%2oVejledning\%20i\%20samfundsøkonomisk\%2ovurdering\%2oaf\%2omiljøproj ekter_net.pdf

Miljø- og Fødevareministeriet (2015), "Nøgletalskatalog, miljøøkonomiske nøgletal 2015" [Ministry of Environment and Food of Denmark, "Environmental Economic Indicators"]. http://mfvm.dk/miljoe/miljoeoekonomiske-noegletal/ 
Miljø- og Fødevareministeriet (2016), "Koncept for effektvurderinger", Internal guideline.

National Audit Office (2013), "Evaluation in government", https://www.nao.org.uk/wpcontent/uploads/2013/12/10331-001-Evaluation-in-government_NEW.pdf

Naturvårdsverket (2003), "Konsekvensanalys steg för steg", https://www.naturvardsverket.se/Documents/publikationer/620-5314-o.pdf?pid=2959

Naturvårdsverket (2014), "Samhällsekonomiska analyser av miljöprojekt - en vägledning" [Environmental Protection Agency: "Socio-economic analyses of environmental projects - a guide"]. http://www.naturvardsverket.se/Documents/publikationer6400/978-91-620-66284.pdf?pid=13982

Norden (2014), "The use of economic instruments in Nordic environmental Policy", TemaNord 2014:549, http://norden.diva-portal.org/smash/record.jsf?pid=diva2\%3A738535\&dswid=-4403

Oikeusministeriö (2007), "Säädösehdotusten vaikutusten arviointi"

Riksantikvarieämbetet (2008), "Metodhandledning I samhällsekonomisk konsekvensanalys", http://samla.raa.se/xmlui/handle/raa/270

Statens Vegvesen (2014 "Håndbok V712 Konsekvensanalyser"

https://www.vegvesen.no/_attachment/704540/binary/1132472?fast_title=H\%C3\%A 5 ndbok+V7 12+Konsekvensanalyser.pdf

Statsministeriet (1998), "Cirkulære om bemærkninger til lovforslag mv. CIR nr 159 af 16/og/1998", http://www.stm.dk/_p_5430.html

Suomen Ympäristökeskus (2006), "Ympäristöpolitiikan taloudellisten vaikutusten arviointi"

Trafikverket (2018), "Analysmetod och samhällsekonomiska kalkylvärden for transportsektorn:ASEK 6.1", https://www.trafikverket.se/for-dig-i-branschen/Planera-ochutreda/Planerings--och-analysmetoder/Samhallsekonomisk-analys-ochtrafikanalys/analysmetod-och-samhallsekonomiska-kalkylvarden-for-transportsektorn-asek/

Transportministeriet (2015),"Manual for samfundsøkonomisk analyse på transportområdet", https://www.trm.dk/da/publikationer/2015/manual-for-samfundsoekonomisk-analyse-paatransportomraadet

Ympäristöministeriö (2011), "Kestävään kehitykseen liittyvien vaikutusten ennakkoarviointi politiikansuunnittelussa ja päätöksenteossa: Suositus arvioinnin työkaluksi" [Finnish Ministry of the Environment, "Ex-ante assessment of sustainable development impacts in policy planning and decision-making: Recommendation for an assessment tool"]. http://www.ym.fi/download/noname/\%7BCA2BC13C-994B-455B-ADgA8F8Do7F17DB6\%7D/27133

Ympäristöministeriö (2013), "Menetelmiä ja tietolähteitä politiikkatoimien vaikutusten arviointiin" [Finnish Ministry of the Environment, "Methods and sources for impact assessment of policies"]. http://www.ym.fi/download/noname/\%7B70DCoDC5-DoBB-4F1C9128-437A80AC6DD8\%7D/40144

See appendix A for reference to specific evaluations. 
Nordic Council of Ministers

Nordens Hus

Ved Stranden 18

DK-1061 Copenhagen $\mathrm{K}$

www.norden.org

\section{Policy instrument evaluation}

What role do evaluations for environmental policies have in the Nordic countries (Denmark, Finland, Norway and Sweden)? And could evaluations be better implemented in order to create and uphold effective and efficient environmental policies? These are the two questions this study aims at answering.

The study focuses on three main areas in regard to ex-ante and ex-post evaluations for environmental policies: Organisation, guidelines and specific evaluations. As a result of the analysis, a number of lessons learnt for the three investigated areas are found and a set of recommendations on how to improve the evaluation of environmental policies in the Nordic countries in the future are provided. 